Portland State University

PDXScholar

Spring 6-5-2014

\title{
Characterization of Methylene Diphenyl Diisocyanate Protein Conjugates
}

Morgen Mhike

Portland State University

Follow this and additional works at: https://pdxscholar.library.pdx.edu/open_access_etds

Part of the Allergy and Immunology Commons, and the Chemistry Commons Let us know how access to this document benefits you.

\section{Recommended Citation}

Mhike, Morgen, "Characterization of Methylene Diphenyl Diisocyanate Protein Conjugates" (2014).

Dissertations and Theses. Paper 1844.

https://doi.org/10.15760/etd.1843

This Dissertation is brought to you for free and open access. It has been accepted for inclusion in Dissertations and Theses by an authorized administrator of PDXScholar. Please contact us if we can make this document more accessible: pdxscholar@pdx.edu. 
Characterization of Methylene Diphenyl Diisocyanate Protein Conjugates

by

Morgen Mhike

A dissertation submitted in partial fulfillment of the requirements for the degree of

\author{
Doctor of Philosophy \\ in \\ Chemistry
}

\author{
Dissertation Committee: \\ Reuben H. Simoyi, Chair \\ Paul D. Siegel \\ Itai Chipinda \\ Niles Lehman \\ Shankar B. Rananavare \\ Robert Strongin \\ E. Kofi Agorsah
}

Portland State University 2014 
(C) 2014 Morgen Mhike 


\begin{abstract}
Diisocyanates (dNCO) such as methylene diphenyl diisocyanate (MDI) are used primarily as cross-linking agents in the production of polyurethane products such as paints, elastomers, coatings and adhesives, and are the most frequently reported cause of chemically induced immunologic sensitization and occupational asthma (OA). Immune mediated hypersensitivity reactions to dNCOs include allergic rhinitis, asthma, hypersensitivity pneumonitis and allergic contact dermatitis.

There is currently no simple diagnosis for the identification of dNCO asthma due to the variability of symptoms and uncertainty regarding the underlying mechanisms. Immunological sensitization due to dNCO exposure is traditionally thought to require initial conjugation of the $\mathrm{dNCO}$ to endogenous proteins to generate neoantigens, which trigger production of dNCO specific T lymphocytes and ultimately dNCO specific IgE. Testing for $\mathrm{dNCO}$-specific IgE, for diagnosis of $\mathrm{dNCO}$ asthma is however, only specific (96-98\%) but not sensitive (18-27\%). The low prevalence of detectable dNCO specific IgE has been attributed to both assay limitations and a potential IgE-independent dNCO asthma mechanism(s). The identity of the conjugated proteins responsible for the sensitization also remains unknown. It is also not clear whether dNCOs bind to extracellular, cell membrane, or intracellular proteins as a way of triggering non-IgE asthma. Standardization and optimization of immunoassays used to screen for dNCO specific antibodies in sera is important if its utility as a dNCO asthma diagnostic tool is to be achieved. This will potentially improve sensitivity and allow comparison of results
\end{abstract}


across studies. Current studies on assays of dNCO-specific IgE and IgG lack or have limited characterization of the conjugates used.

Diisocyanates bound to hemoglobin (Hb), human serum albumin (HSA), and THP-1 proteins were quantified by HPLC with fluorescence detection. Proteomic tandem mass spectrometry (MS) was used to delineate TDI and MDI specific amino acid binding sites on $\mathrm{Hb}$ as well as identification of proteins from MDI exposed THP-1 cells. The trinitrobenzene sulfonic acid assay (TNBS) and SDS gel electrophoresis were used to evaluate extent of intra and intermolecular cross-linking in dNCO-HSA conjugates. Binding of monoclonal antibodies (mAbs) to dNCO bound proteins in enzyme-linked immunosorbent assay (ELISA) was used to evaluate antigenicity of dNCO-protein conjugates.

The amount of dNCO binding to HSA and $\mathrm{Hb}$ increased with the concentration of the dNCO used for conjugation. All the dNCOs reacted with HSA more than with $\mathrm{Hb}$. Eight binding sites were observed with both MDI and TDI on $\mathrm{Hb}$. The N-terminal valines of both the alpha and beta subunits on $\mathrm{Hb}$, lysine 40 of the alpha subunit and lysine 61 of the beta subunit were common binding sites for both TDI and MDI. Lysine 7 of the alpha subunit and lysines 8, 65 and 66 of the beta subunit were unique to MDI. On the other hand, lysines 11 , and 16 of the alpha subunit and lysines 17 and 144 of the beta subunit were unique to TDI. Protein bound MDI was detected in a dose-dependent manner in membrane and cytoplasm fractions of MDI exposed THP-1 cells. MDI was also detected in 11 of the 13 cytoplasmic protein bands. The extent of MDI intracellular protein binding was not affected by cytochalasin $\mathrm{D}$, a chemical that binds actin filaments and 
inhibits active uptake into cells. The extent of cross-linking shown using the TNBS assay was found to increase with amount of dNCO used. Clear bands from both intra and intermolecular cross-linking were observed on all dNCO-Hb/HSA SDS gels. Using ELISA, both TDI-Hb and TDI-HSA conjugates were reactive to monoclonal antibodies produced against TDI conjugated HSA indicating that $\mathrm{dNCO}-\mathrm{Hb}$ is also antigenic.

The best characterization of dNCO-protein conjugates is achieved by the quantitative determination of conjugated dNCO per mole of protein as well as determining the extent of $\mathrm{dNCO}$ cross-linking. Although HSA is more reactive to dNCOs than other serum proteins such as $\mathrm{Hb}$, contribution from other serum proteins to development of OA should not be overlooked as $\mathrm{dNCO}-\mathrm{Hb}$ was found to be reactive to dNCO specific mAbs. dNCO-conjugated proteins identified in the soluble fraction of MDI exposed THP-1 cells were all of intracellular origin suggesting that MDI can cross the cell membrane and react with intracellular proteins. The entry of MDI into live cells is a passive process, as the extent of intracellular binding was not affected by cytochalasin D. The present study support the potential involvement of dNCO-haptenated membrane and intracellular proteins in development of non-IgE dNCO asthma. 
TO MY MOTHER AND LATE FATHER - I OWE EVERYTHING TO YOU 


\section{ACKNOWLEDGEMENTS}

First, I would like to thank my three advisers, Dr. Reuben H. Simoyi, Dr. Paul D. Siegel, and Dr. Itai Chipinda for their support throughout my studies. They introduced me into the fascinating fields of chemical kinetics and diisocyanate induced immunological sensitization. Words cannot explain how grateful I am for their mentorship and guidance throughout my research.

I would also want to express my gratitude to all members of my dissertation committee, Drs. Niles Lehman; Shankar B. Rananavare, Robert Strongin, and E. Kofi Agorsah for their time and invaluable help in this work. It was a privilege to have them in my committee. I wish to thank past and present members of the Simoyi Research Group in particular Dr. Moshood K. Morakinyo, Dr. Risikat A. Adigun, Dr. Wilbes Mbiya, and Kudzanai Chipiso.

My gratitude also goes to Dr. Don Beezhold and his ACIB team at CDC/NIOSH Morgantown for hosting me for my $\mathrm{PhD}$ dissertation work. I should mention particularly the following people, Dr. Justin M. Hettick, Toni A. Bledsoe, Brandon F. Law, Angela R. Lemons, Dr. Ajay P. Nayak, and Dr. Brett J. Green. Their help with various assays, constructive criticism and discussions, helped me get this work to this stage.

I could not have achieved this degree without the support and encouragement of my family. Many thanks are due to my parents who always supported me to achieve my dream and provided all the financial and moral support I needed to succeed. 


\section{TABLE OF CONTENTS}

ABSTRACT

DEDICATION iv

ACKNOWLEDGEMENTS $\mathrm{v}$

LIST OF TABLES Ix

LIST OF FIGURES - X

LIST OF ABBREVIATIONS xi

1. INTRODUCTION 1

1.1. Industrial and commercial uses of isocyanates 1

1.2. Chemistry of diisocyanates 3

1.3. Reaction pathways in the biological system 4

1.4. Health Effects of MDI Exposure $\quad 5$

$\begin{array}{ll}\text { 1.4.1. Inhalation Exposure } & 6\end{array}$

1.4.2. Dermal exposure $\quad 6$

1.4.3. Hypersensitivity 6

1.5. Reaction mechanisms of protein binding $\quad 7$

1.6. Development of Occupational asthma 9

$\begin{array}{lr}\text { 1.7. Diagnosis of diisocyanate asthma } & 12\end{array}$

1.8. Methods for characterization of MDI-protein adducts 13

2. INSTRUMENTATION, MATERIALS AND METHODS 17

2.1. Instrumentation 17

2.1.1. Mass Spectrometry 17

2.1.2. Electrospray Ionization 17

2.1.3. High Performance Liquid Chromatography (HPLC) 18

2.1.4. Spectrophotometry 18

$\begin{array}{lr}\text { 2.2. Materials } & 19\end{array}$

$\begin{array}{ll}\text { 2.2.1. Chemicals } & 19\end{array}$

2.3. Methods 19

2.3.1. Preparation of dNCO-protein adducts 19

2.3.2. THP-1 MDI Conjugations $\quad 21$

2.3.3. THP-1 exposure controls 22

2.3.4. Protein estimation $\quad 23$

2.3.5. The TNBS assay $\quad 23$

2.3.6. Hydrolysis and extraction 24

2.3.7. Derivatization and HPLC analysis 24

2.3.8. Delineation of MDI and TDI specific binding sites on $\mathrm{Hb} \quad 25$ 
2.3.9. Identification of MDI bound proteins 27

2.3.10. Sodium dodecyl sulfate (SDS) gel electrophoresis 27

2.3.11. Enzyme-linked immunosorbent (ELISA) assays 28

3. DEVELOPMENT OF AN HPLC METHOD FOR QUANTIFICATION

OF DIISOCYANATES CONJUGATION TO HSA AND Hb 30

3.1 Introduction 30

3.2. The HPLC method 32

3.2.1. Hydrolysis 32

3.2.2. Extraction 33

3.2.3. Derivatization 34

3.3. Results and discussion $\quad 35$

3.3.1. Optimization of the derivatization reaction 35

3.3.2. Determination of the optimum solvent system for derivatization 35

3.3.3. HPLC analysis of the derivatized MDA 37

3.3.4. Extending the derivatization to TDA and HDA 39

3.3.5. Direct derivatization calibration curves 39

3.3.6. Optimization of the extraction 41

3.3.7. Back extraction 42

3.3.8. Extracted calibration curve 42

3.4. Discussion and conclusion 43

4. CHARACTERIZATION OF METHYLENE DIPHENYL DIISOCYANATE CONJUGATED HUMAN SERUM ALBUMIN AND HEMOGLOBIN 45

4.1. Introduction 45

4.2. Results and discussion 48

4.2.1. Mapping the binding sites of MDI on $\mathrm{Hb}$

4.2.2. Quantification of MDI binding in $\mathrm{Hb}$ and HSA 51

4.2.3. Cross-linking in MDI-HSA- TNBS assay 52

4.2.4. Gel electrophoresis: qualitative assessment of crosslinking In MDI-HSA and MDI-Hb 55

4.2.5. ELISA assessment of percentage of albumin conjugated 58

4.3. CONCLUSION 59 
5. COMPARATIVE ANALYSIS OF TOLUENE DIISOCYANATE AND HEXAMETHYLENE DIISOCYANATE CONJUGATION TO HUMAN SERUM ALBUMIN AND HEMOGLOBIN

5.1. Introduction $\quad 62$

5.2. Results and discussion 63

5.2.1. Mapping TDI binding sites on $\mathrm{Hb} \quad 63$

5.2.2. Quantification of TDI and HDI binding on $\mathrm{Hb}$ and HSA 66

5.2.3. Cross-linking in TDI-HSA: TNBS assay 67

5.2.4. Gel electrophoresis: qualitative assessment of conjugation and crosslinking In TDI/HDI-HSA and TDI/HDI-Hb 68

5.2.5. ELISA assessment of TDI-HSA / Hb 71

5.3. CONCLUSION 72

6. EVALUATING THE POTENTIAL FOR AN IgE INDEPENDENT MECHANISM THROUGH WHICH DIISOCYANATE ASTHMA $\begin{array}{ll}\text { DEVELOPS } & 74\end{array}$

6.1. Introduction $\quad 74$

6.2. Results and discussion 76

6.2.1. Quantification of MDI in the cytoplasm 76

6.2.2. Quantification of MDI in the cell membrane fraction 78

6.2.3. Evaluating the effect of exposure time on the extent $\begin{array}{ll}\text { of MDI binding } & 79\end{array}$

6.2.4. Control experiments $\quad 80$

6.2.5. Detection of MDI in specific SDS gel bands from MDI exposed THP-1 Cells 83

6.2.6. Identification proteins from bands with detectable MDI 85

6.3. CONCLUSION 88

$\begin{array}{lr}\text { REFERENCE LIST } & 90\end{array}$ 


\section{LIST OF TABLES}

Table 3.1: Fluorescence results obtained with $0.16 \mathrm{M}$ boric acid (sodium) buffer solution at $\mathrm{pH} 9.6 \quad 36$

Table 3.2: Fluorescence results obtained with saturated borate buffer 36

Table 3.3: Gradient elution used for HPLC analysis 37

Table 3.5: Extraction efficiencies obtained for dichloromethane and ethyl acetate 41

Table 3.6: Extraction solvents chosen for each diamine $\quad 42$

Table 4.1: MDI Hemoglobin conjugation sites $\quad 50$

Table 4.2: Comparison of MDI binding sites in $\mathrm{Hb}$ and HSA 51

Table 4.3: The molar quantities of MDI bound to HSA and $\mathrm{Hb}$ per mole of protein obtained $\quad 52$

Table 4.4: Cross-linking in HSA-MDI evaluated using the TNBS assay 53

Table 5.1 TDI binding sites on $\mathrm{Hb}$ at different concentrations of TDI 64

Table 5.2 Comparative analysis of MDI and TDI binding sites on $\mathrm{Hb}$

Table 5.3: Amount in moles of TDI and HDI conjugated to HSA and Hb 66

Table 5.4 Cross-linking in TDI/HDI-HSA using the TNBS assay. 67

Table 6.1 Moles of MDI from the cytoplasm of MDI-exposed THP-1 cells 77

Table 6.2. Moles of MDI from the membrane of MDI-exposed THP-1 cells $\quad 79$

Table 6.3 Effect of exposure time on MDI binding in the cytoplasm fraction $\quad 80$

Table 6.4. Effect of exposure time on MDI binding in the membrane fraction $\quad 80$

Table 6.5 Amount of MDI detected in the cytoplasm of control exposures $\quad 82$

Table 6.6 Amount of MDI detected in the membrane of control exposures 82

Table 6.7. MDI quantified from gel bands from the cytoplasm fraction 85

Table 6.8. The list of proteins identified from the 13 bands excised from the cytoplasm fraction $\quad 86$ 


\section{LIST OF FIGURES}

Figure 1.1: The general chemical reactions of isocyanates 3

Figure 1.2 Reaction pathways of MDI in biological systems. 5

Figure 1.3: Reaction products of human serum albumin with MDI. 8

Figure 1.4: Possible mechanism(s) leading to the development of hypersensitivity

$\begin{array}{ll}\text { Reactions and OA upon MDI exposure. } & 11\end{array}$

Figure 2.1: Chemical structures for the different diisocyanates used in this study 19

Figure 3.1: Structures of the amino acids that react with isocyanates. 331

Figure 3.2: Hydrolysis of MDI-protein conjugates in acid and high temperature 33

Figure 3.3: The reaction of a primary amine with fluorescamine 34

Figure 3.4: MDA chromatograms from HPLC analysis. 38

Figure 3.5: MDA chromatograms from HPLC analysis from 17-20 minutes. 39

Figure 3.6: Calibration curve obtained from the direct derivatization of MDA 40

Figure 3.7: Calibration curve obtained when MDA extracted from $0.5 \mathrm{mg} / \mathrm{ml} \mathrm{Hb} 43$

Figure 4.1: Tandem mass spectrum of the hemoglobin subunit $\beta$ fragment 1-17

Conjugated to MDI on the N-terminal valine residue. 49

Figure 4.2: Total MDI bound per mole of HSA and the approximate number of MDI That are cross-linked $\quad 54$

Figure 4.3: An 8\% denaturing gel of MDI: HSA 56

Figure 4.4: An 8\% native gel of MDI: HSA 57

Figure 4.5: denaturing $4 \%$ to $20 \%$ gradient gel of MDI-Hb 58

Figure 4.6: Immunoassay of MDI haptenated HSA 59

Figure 5.1: denaturing 8\% gel of TDI-HSA. 69

Figure 5.2: denaturing 12\% gel of TDI-Hb 70

Figure 5.3: Immunoassay of TDI haptenated HSA and Hb 72

Figure 6.1. A $12 \%$ denaturing gel of MDI exposed THP-1 cells' cytoplasm fraction $\quad 84$ 
LIST OF ABBREVIATIONS

\begin{tabular}{ll} 
ACD & allergic contact dermatitis \\
AP & alkaline phosphatase \\
APC & antigen presenting cell \\
ATCC & American Type Culture Collection \\
CID & collision-induced dissociation \\
CSN & culture supernatant \\
DDI & distilled deionized \\
DIY & Do It Yourself \\
dNCO & diisocyanates \\
ELISA & enzyme linked lmmunosorbent assay \\
ESI & electrospray ionization \\
Hb & Hemoglobin \\
HDI & 1, 6-hexamethylene diisocyanate \\
HMW & High Molecular Weight \\
HPLC & High Performance Liquid Chromatography \\
HPLC-Q-TOF & high performance liquid chromatographic- \\
IgG & immuadrupole-time of flight mass spectrometry \\
HSA & human serum albumin \\
\hline
\end{tabular}


IPDI

$\mathrm{KLH}$

LOD

LMW

$\mathrm{m} / \mathrm{z}$

$\mathrm{mAb}$

MDA

MDI

MHC1

MHC11

Mwt

$\mathrm{NCO}$

NIOSH

NSBHR

$\mathrm{OA}$

$\mathrm{OCF}$

PEFP

PBS

PBSTM

PEG

RT isophorone diisocyanate

keyhole limpet hemocyanin

Limit of Detection

low molecular weight

mass to charge ratio

monoclonal antibody

4, 4'-Methylene Dianiline

4,4' methylene diphenyl diisocyanate

major histocompatibility complex 1

major histocompatibility complex 11

molecular weight

isocyanate

National Institute for Occupational Safety and

Health

Nonspecific bronchial hyper responsiveness

occupational asthma

One-component foam

Peak Expiration Flow Rates

phosphate buffered saline

phosphate buffered saline tween milk

polyethylene glycol

room temperature 
SBPT

SDS-PAGE

SPF

2, 4-TDA

2, 4-TDI

TNBS

TOF

$\mathrm{UV} / \mathrm{Vis}$
Specific bronco-provocation testing

sodium dodecyl sulphate-poly acrylamide gel

electrophoresis

Spray Polyurethane Foam

2, 4-toluene diamine

2, 4-toluene diisocyanate

2, 4, 6-trinitrobenzenesulphonic acid

time of flight

ultra violet/visible 


\section{CHAPTER 1 INTRODUCTION}

\section{I.1 Industrial and commercial uses of isocyanates}

Diisocyanates $(\mathrm{dNCO})$, characterized by the very highly reactive $\mathrm{N}=\mathrm{C}=\mathrm{O}$ group, are used primarily as cross-linkers in the production of polyurethane products such as paints, elastomers, coatings, and adhesives ${ }^{1}$. The most commonly used monomeric diisocyanates include methylene diphenyl diisocyanate (MDI), 2, 4 and 2,6-toluene diisocyanate (TDI), and hexamethylene diisocyanate (HDI $)^{2}$. Other less commonly used diisocyanates include naphthalene diisocyanate (NDI), methylene biscyclohexylisocyanate (HMDI) (hydrogenated MDI), and isophorone diisocyanate (IPDI). Examples of widely used polyisocyanates include MDI and TDI based polyisocyanates, HDI biuret, and HDI isocyanurate. MDI is increasingly replacing TDI in the production of flexible and rigid foams, particle board and wood binders, paints and coatings, adhesives, sealants, elastomers and spandex fibers ${ }^{3}$. It is also used for consolidating loose rock zones in coal mining or tunneling.

During production of polyurethane products, the NCO group reacts with hydroxyl groups to form the polyurethane polymers until essentially all available NCO groups have reacted. This process is called 'curing'. Some products contain free NCO groups and are meant to undergo the curing process during use. Adhesives are a good example of dNCOs that will undergo curing during use. These are applied in an uncured form and bind to wood as they cure. There are also certain products such as 
mattresses, pillows, and bowling balls, which contain already cured NCO groups before they are sold. Cured dNCOs are usually considered less toxic because they do not contain free NCO groups ${ }^{4}$. The curing reaction in most cases leaves sequestered pockets of unreacted NCO groups, which potentially pose a risk of dNCO exposure. Diisocyanates are used in settings, such as construction (adhesives, home insulation), and the automotive industry (paints and truck bed liners), where an end-use curing process is part of the functional performance of the product. These pose greater risk of exposure to $\mathrm{dNCO}$. There is an increasing availability of uncured $\mathrm{dNCO}$ to both the professional applicator, as well as the do it yourself (DIY) consumer. The use of polyurethane foam for insulation is increasing as federal and state government programs create incentives for their use in increasing energy efficiency. Pour-in-place (PIP), spray polyurethane foam (SPF) and one-component foam (OCF) cans are used in the arts industry for sculpture and mold making. Auto refinishing and repair, marine leisure craft maintenance and repair, and floor and deck maintenance and repair, all use uncured polyurethane products. Polyurethane coatings are used to seal concrete and refinish floors. Polyurethane sealants are used for glass installation of windshields and side windows. Adhesives are used domestically for woodworking and bookbinding. All these are dNCO-containing products that pose risk of exposure to workers and end users. US federal agencies such as OSHA and NIOSH acknowledge the health risks resulting from occupational exposure to dNCOs and have established occupational exposure limits that are supposed to be protective to workers over an $8 \mathrm{hr}$ time weighted average working shift. The OSHA mandated permissible exposure 
limits (PEL) for TDI and MDI are $0.02 \mathrm{ppm}$ as ceiling levels. The NIOSH recommended exposure limits (REL) for these two dNCOs are currently set as $5 \mathrm{ppb}$.

\subsection{Chemistry of diisocyanates}

Diisocyanates are highly reactive electrophilic compounds that undergo nucleophilic addition reactions with a variety of nucleophiles such as amines, alcohols, and thiols. Under physiological conditions, isocyanates would have the following order of reactivity with the various nucleophiles: sulfhydryl's >> primary amines > secondary amines $>$ hydroxyls ${ }^{5}$.Figure 1.1 illustrates the various reactions an isocyanate would undergo with nucleophilic compounds.

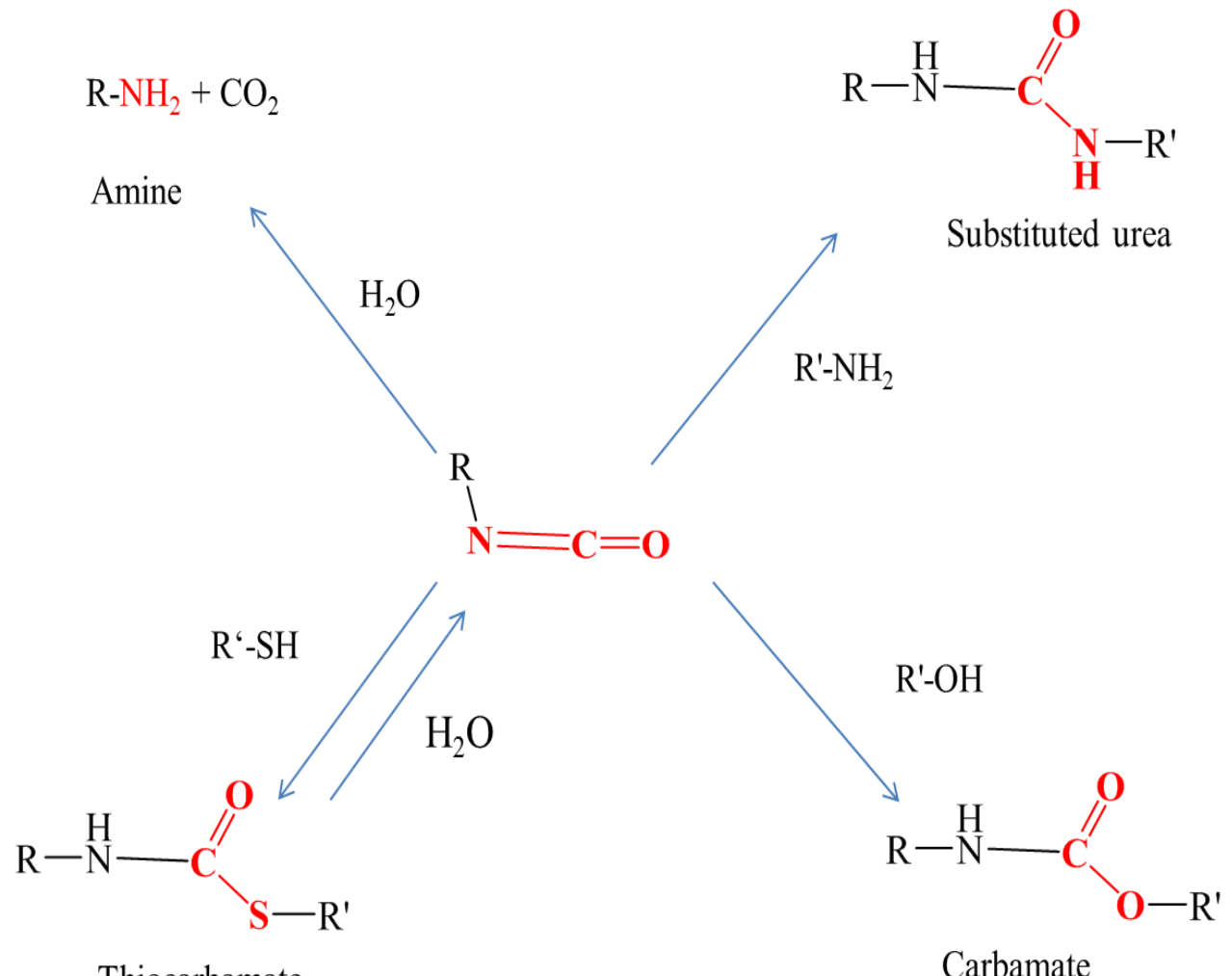

Thiocarbamate

Carbamate

Figure 1.1: The general chemical reactions of isocyanates 


\subsection{Reaction pathways in the biological system}

In the biological environment, MDI can undergo several reactions ${ }^{6}$. Its reaction with biomolecules to form adducts is of particular interest. Several biomolecules in the biological environment are found that possess hydroxyl, amino, and sulfhydryl groups. MDI can react with these biomolecules after entry into the body. As Figure 1.2 shows, apart from its conjugation to biomolecules, two MDI molecules can also react to form MDI urea. Further addition of more MDI molecules to the MDI urea results in MDI polyurea. Another significant competing reaction is MDI's autohydrolysis in aqueous environments to form methylene dianiline (MDA), which is the corresponding diamine from MDI. Because of the abundance of nucleophiles in the physiological environment and high chemical reactivity of diisocyanates, it can be assumed that no unreacted diisocyanates circulate in the body after absorption. 


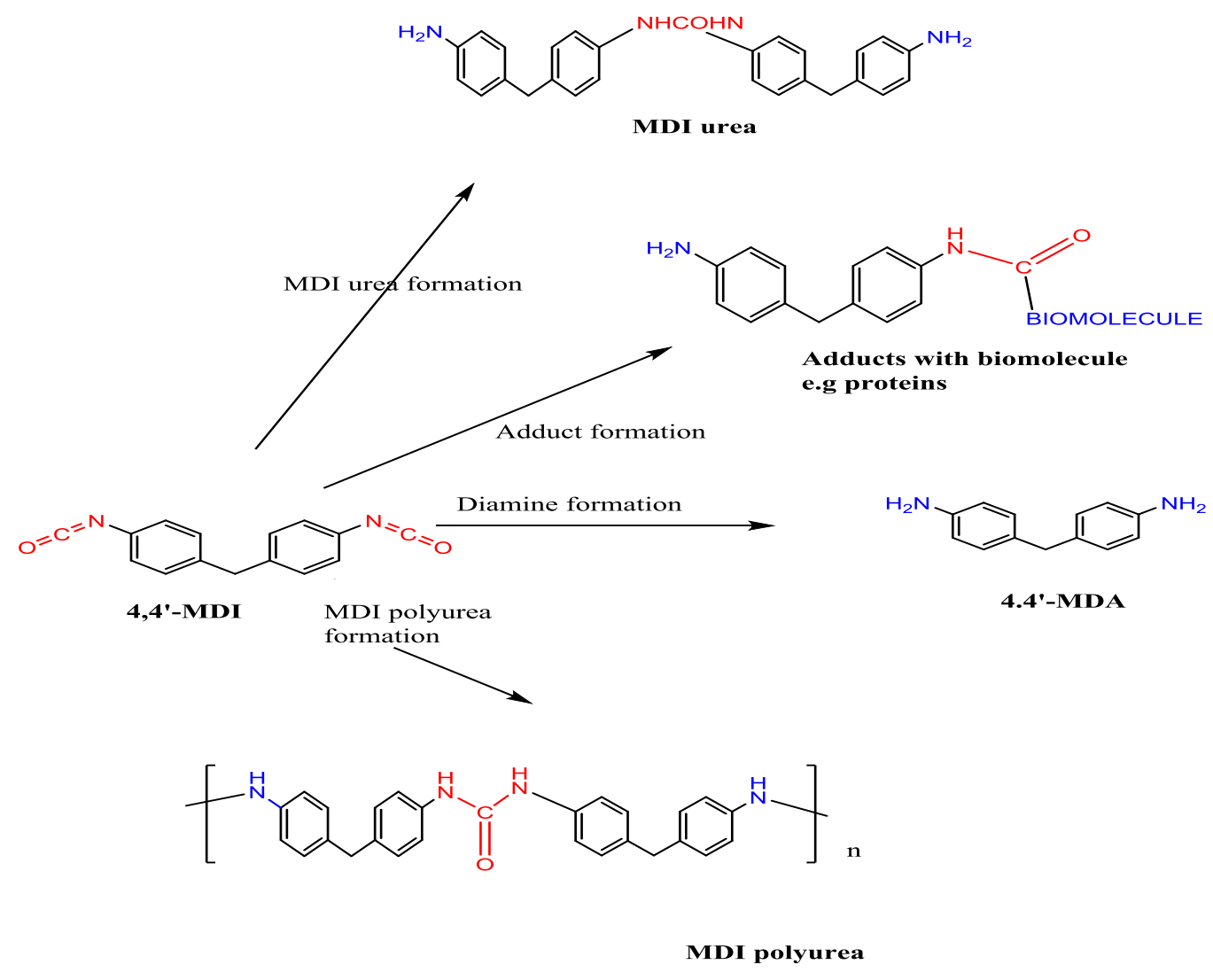

Figure 1.2: Reaction pathways of MDI in biological systems.

\subsection{Health Effects of MDI Exposure}

Both the respiratory tract and skin are potential routes of dNCO exposure. Although MDI has a low vapor pressure, it becomes airborne during spraying operations and typically exists as particles or aerosols. Studies have also shown that dermal contact to dNCO can induce respiratory tract sensitization in animals ${ }^{7}$. A follow up survey of new workers exposed to liquid MDI demonstrated an increased risk for developing new onset asthma-like symptoms ${ }^{8}$. Isocyanate-containing product breakdown or leaching have been raised as potential sources of diisocyanate exposure to the public 9 . 


\subsubsection{Inhalation Exposure}

4, 4'-MDI is a solid at room temperature and has a very low vapor pressure $(\leq 0.01$ Pa). MDI containing polyurethane products that require mixing of the MDI with polyols and then spraying at the site of application pose the greatest risk of inhalation exposure $^{10,11}$.

\subsubsection{Dermal exposure}

Dermal exposure to MDI in workers has been well-documented ${ }^{8,12,13}$. Dermal sensitization to MDI has been reported in animal studies ${ }^{14,15}$. In domestic settings, dermal exposure to MDI from use of do it yourself (DIY) products is possible. Due to the presence of MDI in polyurethane based paints, adhesives and coatings, dermal exposure can occur during both spraying and other application type operations and at times in domestic settings by coming in contact with a product before it completely cures.

\subsubsection{Hypersensitivity}

Diisocyanates are the most frequently reported cause of chemically-induced occupational asthma $(\mathrm{OA})$ and are capable of producing both immune- and irritantmediated asthmas ${ }^{16,17}$. The prevalence of diisocyanate asthma among exposed workers ranges from $5 \%-15 \%{ }^{17}$. Over 200,000 workers are directly employed in the production and use of isocyanates worldwide in various industries ${ }^{18}$ and millions more are potentially exposed through use of dNCO containing products. MDI is one of the dNCOs known to cause occupational asthma. Common direct toxicities of dNCO exposure include respiratory ${ }^{19}$, dermal and mucous membrane irritation. Immune- 
mediated hypersensitivity reactions to dNCOs include allergic rhinitis ${ }^{20}$, asthma, hypersensitivity pneumonitis ${ }^{21,22}$ and allergic contact dermatitis ${ }^{23}$. Despite MDI accounting for approximately $60 \%$ of the $\mathrm{dNCO}$ global market, most of the published biomedical dNCO research studies have used toluene diisocyanate (TDI). This is possibly because of two reasons (i) from about 15 years ago and back, TDI was the most used diisocyanate and so researchers were more interested in evaluating effects of exposure to TDI. There was a shift in the market from TDI to MDI use because MDI, being less volatile than TDI, was conceived to pose a lesser risk of exposure than TDI, and (ii) MDI's lower vapor pressure, not only made respiratory exposure less likely, but is technically more challenging to conduct animal inhalation exposure studies $^{24,25}$. MDI is a known respiratory sensitizer based on reported animal and human studies. In humans, health effects due to respiratory hypersensitivity to MDI can range from asymptomatic, mild respiratory symptoms, to severe responses such as hypersensitivity pneumonitis or severe asthma. Death from severe asthma in sensitized subjects has been reported ${ }^{19}$.

\subsection{Reaction mechanisms of protein binding.}

Immunologic MDI sensitization and OA is commonly believed to require initial conjugation of MDI to endogenous proteins to generate neoantigens ${ }^{26}$.These complexes are recognized by antigen presenting cells; leading to the production of dNCO-specific T-lymphocytes and some dNCO-specific B-lymphocytes that mature to dNCO-specific IgE secreting plasma cells. However, the functional form of the 
antigens responsible for sensitization reactions are still unknown. Methylenediphenyl diisocyanate- haptenated human serum albumin (MDI-HSA) is used to measure specific anti-MDI antibody in workers, but these haptenated proteins are usually poorly characterized. Diisocyanates are reactive, bi-functional electrophilic compounds. When reacted with proteins under aqueous conditions they can covalently bind to protein amines and reversibly to thiols ${ }^{27}$. Multiple species are formed when dNCOs react with proteins as demonstrated by the MDI-albumin reaction products depicted in Figure 1.3. It must also be noted that a single protein molecule such as human serum albumin may be haptenated at multiple nucleophilic sites to produce one or more of the species noted in Figure $1.3^{28}$.

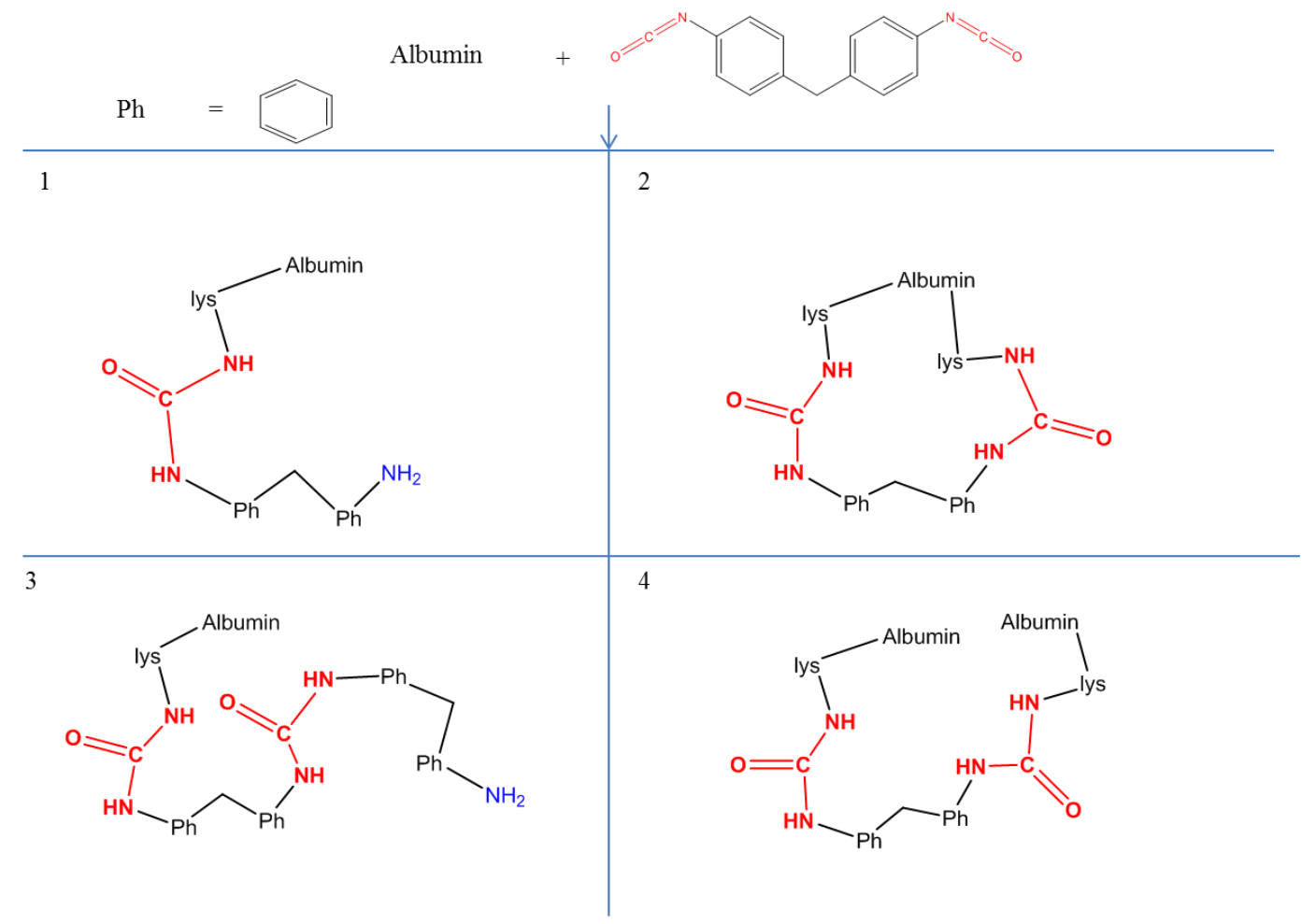

Figure 1.3: Reaction products of human serum albumin with MDI. [1] Monomeric dNCO binding, [2] Intra-molecular crosslinking, [3] polymeric binding onto a protein site, and [4] Inter molecular crosslinking. 


\subsection{Development of occupational asthma}

Occupational asthma (OA) is a complex disease with genetic, behavioral and environmental factors ${ }^{29}$. OA is a type of asthma that is caused by conditions attributable to a particular work environment. There are essentially two types of OA: immunologic OA which is characterized by an asymptomatic latency period of exposure necessary for acquiring immunologic sensitization, and non-immunologic OA, which has no latency period and occurs upon exposure to high concentrations of irritants ${ }^{30}$. Occupational sensitizers are either high molecular weight (HMW, e.g. proteins) or low molecular weight (LMW) compounds which induce asthma by producing specific IgE antibodies or possibly trigger other immune cell mediated mechanisms. HMW agents act as complete antigens, whereas LMW chemicals, such as MDI, must first react with autologous proteins to produce a functional allergen ${ }^{21,31}$. Agents that are of insufficient volume to be allergenic and must bind covalently to a protein to become allergens are referred to as haptens. The fate of diisocyanate in the body and the ultimate antigenic form(s) are unknown ${ }^{32}$. Haptenation to proteins is believed to be the initial step for these sensitization reactions.

Diisocyanates do not consistently induce specific IgE antibodies ${ }^{33,34}$. Therefore testing for dNCO-specific IgE for diagnosis of $\mathrm{dNCO}$ asthma is specific (96-98\%), but insensitive (18-27\%). One possible explanation is that sensitization of the respiratory tract by dNCO can be achieved by more than one immunologic mechanism, including some that are $\mathrm{IgE}$ independent. Another possibility is that assay methods currently 
being used are not sensitive enough to detect certain low levels of anti-dNCO-IgE. There are several issues with immunoassays being used, (i) most of them do not report characterization of the HSA-MDI conjugates used to detect MDI specific IgE, (ii) most still do not report how the conjugates were prepared, and (iii) some misinterpret results from the characterization of the HSA-MDI conjugates. It is worth noting also that the circulating life of specific $\operatorname{IgE}$ is 2.5 days but after cessation of exposure, $\operatorname{IgE}$ antibody is detected between 4 months and 2 years ${ }^{2,35}$. The observation that dNCO asthma has similar clinical and pathologic features of atopic disease, but that it is not consistently associated with production of specific $\operatorname{IgE}$ or up-regulation of $\operatorname{IgE}$ receptors ${ }^{36}$ suggests the involvement of IgE-independent immune mechanisms including cell-mediated and mixed reactions. The figure below shows the possible ways by which OA and hypersensitivity reactions can develop upon MDI exposure. 


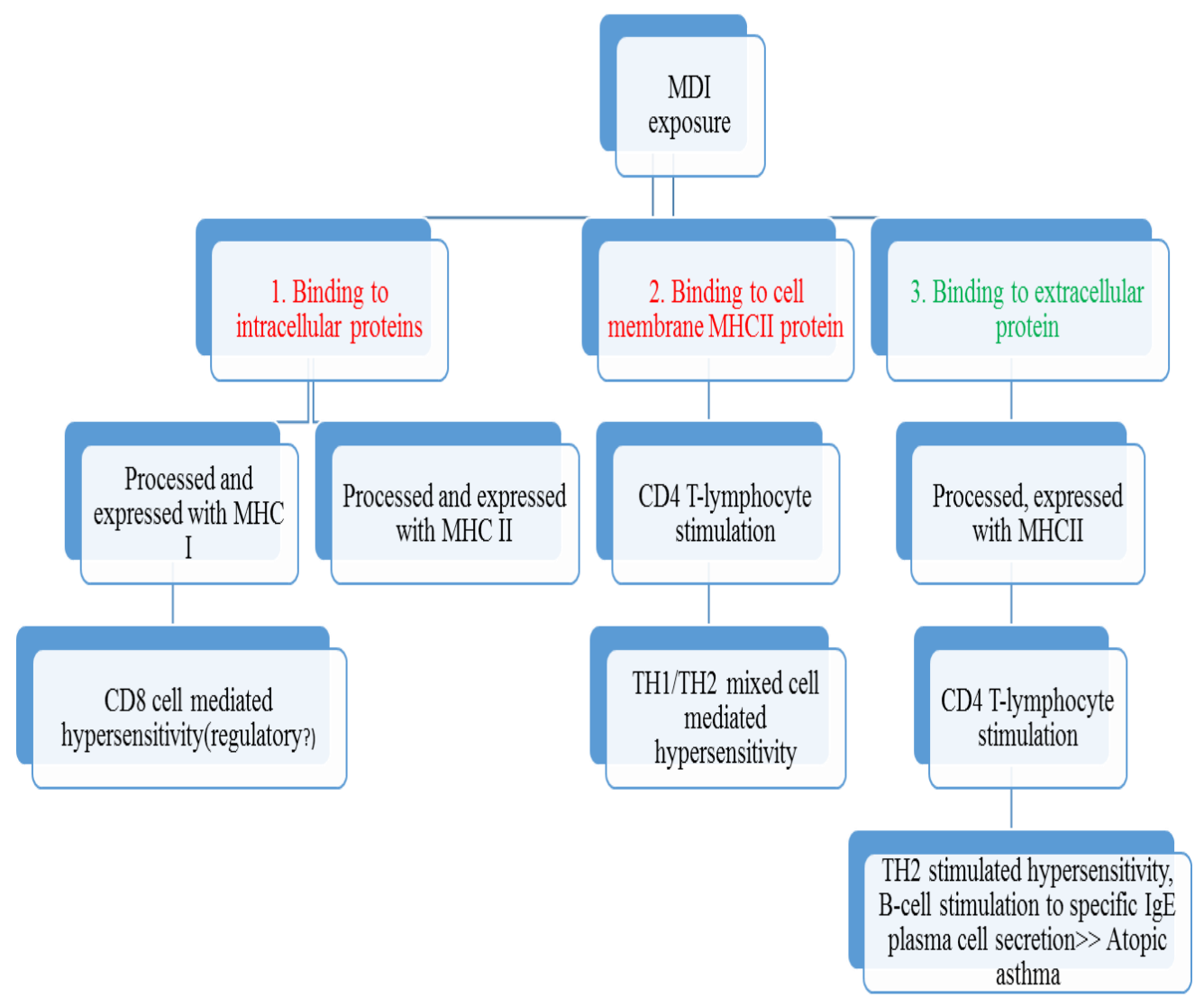

Figure 1.4: Possible mechanism(s) leading to the development of hypersensitivity reactions and $O A$ upon MDI exposure.

OA can also develop through a non-immunologic mechanism (irritant-induced asthma). This occurs when an individual is exposed to high concentrations of respiratory irritants resulting in injury to the epithelial system. The main target of injury, though not yet identified, could be bronchial epithelium which, when denuded, exposes nerve endings resulting in neurogenic inflammation, loss of relaxing epithelial factors, release of inflammatory mediators and pro-inflammatory cytokines, secretion 
of growth factors for epithelial cells, smooth muscle cells, fibroblasts and matrix degradation ${ }^{37-39}$.

\subsection{Diagnosis of diisocyanate asthma}

There is currently no simple way to diagnose diisocyanate asthma due to the variability of symptoms, the uncertainty regarding the underlying mechanisms, and the multiple other potential occupational and environmental causes of a worker's asthma. Diisocyanate asthma, in general, displays the same pathological hallmarks of high molecular weight (protein) allergic asthmas, including eosinophilic inflammation and increased airway reactivity. This prompted researchers to suggest the use of dNCOspecific IgE for dNCO asthma diagnosis. The role of $\mathrm{IgE}$ in the underlying pathophysiology of dNCO asthma is however a matter of debate ${ }^{28}$. Ott et al ${ }^{40}$ discussed the issues surrounding immunoassay standardization and variability of antigenicity of dNCO haptenated protein preparations which are central to both asthma diagnosis and questions of pathophysiological mechanism(s). Diisocyanate haptenation and characterization of resultant antigens remains problematic. This is due to the high reactivity and divalent nature of dNCOs, resulting in self-polymerization, intramolecular and intermolecular protein crosslinking.

The main challenge in the diagnosis of dNCO sensitization is that current methods are not sufficiently sensitive (25\% for $\operatorname{IgE}$ and $43 \%$ for $\operatorname{IgG}-$ Specific $\operatorname{IgG}$ is considered a marker of exposure rather than disease) ${ }^{40}$, and the actual prevalence of dNCOspecific IgE reported in studies varies greatly ${ }^{41}$. There are also multiple other 
potential occupational and environmental causes of asthma. It can be difficult to distinguish diisocyanate asthma from irritant aggravation of underlying asthma. The major tools are clinical history including exposure questionnaire; spirometry and nonspecific inhalation challenge. Methacholine challenge is used to identify hyperactive reactive airways, a hallmark of asthma. Lack of hyperreactive airways is used to rule out asthma. False negatives are common if subjects are on corticosteroids. Although documenting the relationship between symptoms and work can be helpful, it is more reliable at excluding rather than confirming a diagnosis ${ }^{29}$. Specific broncho provocation testing (SBPT) with a diisocyanate in a specialized inhalation challenge laboratory is regarded as the gold standard for $\mathrm{dNCO}$ asthma diagnosis. This is, however, an expensive and technically difficult technique that is mainly used for research purposes in the United States and even so, the method is neither $100 \%$ sensitive nor specific ${ }^{33,42,43}$. Measurements of peak expiratory flow rates (PEFR) at and away from exposure environment has been used for diagnosis of dNCO asthma 30,31. However, sensitivity ranges from $70 \%-100 \%$ and specificity from 50\%-100\% against $\mathrm{SBPT}^{32,34}$.

\subsection{Methods for characterization of MDI-protein adducts}

There are several methods that have been used to characterize dNCO-protein conjugates ${ }^{35,36}$ for standardization of dNCO-specific antibody detection immunoassays and also for biomonitoring assays of dNCO exposure. Some high performance liquid chromatographic (HPLC) and gas chromatographic (GC) methods have been developed and used which involve use of electrochemical and mass 
detection ${ }^{37,44}$ for biomonitoring of dNCOs exposure by measuring their respective hydrolysis amine products following strong acid or base treatment. These are expensive methods that have limited application, as they do not provide qualitative information. The trinitrobenzene sulfonic acid (TNBS) assay has also been used for characterization of dNCO-protein conjugates and results have often been misinterpreted. The TNBS assay is based on loss of a protein's primary amine reactivity with TNBS after haptenation. Since amines are the most observed sites of dNCO conjugation on proteins, some investigators have taken the absolute loss of amine reactivity to TNBS as a quantitative marker of moles of dNCO bound per mole of protein. Although this may be a good approximation with mono-isocyanates, with dNCOs, there is a high likelihood of conjugation of one isocyanate moiety with subsequent hydrolysis of the other isocyanate to regenerate a primary amine (Fig 1.3). In this case, there would be no net loss of amine causing an underestimation of moles dNCO bound by the TNBS assay. Alternatively, if $\mathrm{dNCO}$ polymerizes onto itself the TNBS will underestimate the total amount of dNCO bound. The TNBS assay, when used in conjunction with other analytical methods is a better indicator of cross-linking (intra- and intermolecular) than of total dNCO bound. Polyacrylamide gel electrophoresis and Western blot analyses provide more qualitative assessment of the dNCO conjugates, but are generally of poor resolution and at best semi-quantitative.

OA induced by MDI has been described in workers in which MDI-specific IgE can be measured and more often in which immunoassay for MDI-specific IgE is negative ${ }^{8}$. 
Considerable findings from both human and animal studies suggest that an alternative immune-mediated (possibly Th-1 or CD8+) mechanism(s) of dNCO asthma may be involved, suggesting that the target haptenated proteins may be intracellular or membrane bound. ${ }^{45-48}$. Recent studies suggest involvement of T-lymphocytes in diisocyanate asthma rather than through induction and suppression of $\operatorname{IgE}$ synthesis as T-lymphocytes release potent cytokines causing direct inflammation ${ }^{49,50}$. CD8+ T cell numbers increase in the peripheral circulation of diisocyanate asthmatics following workplace exposure ${ }^{51}$. CD8+ T cell clones from two diisocyanate asthmatics exhibited a mixed Th1/Th2-like phenotype and secreted high levels of both IFN- $\gamma$ and IL- 5 but not IL-4, contrary to the profile of T cell clones that are preferentially expanded from atopic individuals, which are primarily CD4+ and produce IL-4 and IL-5 but not IFN- $\gamma^{46,52}$.

As noted above, there are knowledge gaps with respect to the ultimate allergenic haptenated proteins, and mechanisms of asthmatic sensitization. Better methods of characterizing MDI-haptenated proteins used for antibody detection and evaluation of the ability of MDI to bind both cell membrane and intracellular proteins would provide data that would help address these knowledge gaps.

The specific objectives addressed in this thesis are (i) Development of sensitive and specific method(s) for quantitative evaluation and characterization of MDI-protein conjugates, (ii) Evaluation of historical methods for characterization of dNCO-protein 
conjugates, (iii) Mapping out specific MDI and TDI binding sites on $\mathrm{Hb}$ using proteomic analysis of tryptic peptides from MDI-protein conjugates, (iv) Demonstration of MDI binding to proteins in cellular fractions of exposed THP-1 cells, (v) Identification of proteins from THP-1 cells. 


\section{CHAPTER 2}

\section{INSTRUMENTATION, MATERIALS AND METHODS}

\subsection{INSTRUMENTATION}

\subsubsection{Mass Spectrometry}

Electrospray ionization mass spectrometry (ESI- MS) detects small mass shifts in large biomolecules making it a very useful tool for studying protein haptenation. Tandem mass spectrometry enables the acquisition and structural elucidation of both native and modified proteins and peptides. The technique is also very useful for identification of unknown proteins from complex protein mixtures. ESI-MS was employed in this project for both identification and characterization of modified proteins due to dNCO conjugation as well as identifying unknown proteins from dNCO exposed THP-1 cells.

\subsubsection{Electrospray Ionization}

The mass spectrometer used in these studies was a Micromass QTOF-II (Waters Corporation, Milford, MA) quadrupole time-of-flight mass spectrometer (qTOF-MS). Analyte ions were generated by positive-mode electrospray ionization (ESI). The ESI involves droplet formation, droplet shrinkage and gaseous ion formation ${ }^{53,54}$. Tryptic peptides were separated on a Waters nanoACQUITY UPLC system (Waters Corporation, Milford, MA, USA). Positive ion nanoelectrospray was performed using $10-\mu \mathrm{m}$ Pico-Tip (Waters) emitters held at a potential of $+3.5 \mathrm{kV}$. The cone voltage was held constant at $+40 \mathrm{~V}$ for all experiments. Dry nitrogen desolvation gas was supplied to the instrument via a nitrogen generator (NitroFlowLab, Parker Hannifin, Haverhill, MA, USA). [Glu]1-Fibrinopeptide B (100 fmol/ $\mu$ l in 75:25 A/B) was supplied to an 
orthogonal reference probe ${ }^{55}$. Ultra-high purity (UHP) argon was used as collision gas. The collision energy was set to $6 \mathrm{eV}$ (1-s low energy scan) and a $15-$ to $30-\mathrm{eV}$ ramp (1-s high energy scan).

\subsubsection{High Performance Liquid Chromatography (HPLC)}

For quantification of MDI binding in pure proteins and THP-1 cell fractions, Reverse Phase High Performance Liquid Chromatography (RP-HPLC) was employed.

Following hydrolysis, extraction and derivatization of the amine hydrolysis product, the resulting fluorescent complex was injected onto a SUPELCO discovery C18 column at $1 \mathrm{ml} / \mathrm{min}$ and analyzed on a Shimadzu Prominence HPLC system consisting of an online vacuum degasser (model DGU-20A5), a quaternary pump (model LC-20AT), an auto sampler (model SIL-10AD-VP) and a fluorescence detector (model RF-10AXL). The HPLC system is controlled by EZStart software version 7.3. The resulting MDAfluorescamine complex was excited at $410 \mathrm{~nm}$ and emission measured at $510 \mathrm{~nm}$.

\subsubsection{Spectrophotometry}

The extent of cross linking using the TNBS assay was evaluated using ultraviolet/visible light (UV/Vis) on a Beckman Coulter spectrophotometer (model DU 800, Beckman Coulter, Somerset, NJ, USA). The spectrophotometer was interfaced to an IBM PC computer and used the DU Series 800 Software (Fullerton, CA). Path length of the cuvette was $1 \mathrm{~cm}$. 


\subsection{MATERIALS}

\subsubsection{Chemicals}

Unless otherwise specified, all reagents were acquired from Sigma-Aldrich (St. Louis, MO, USA) and used without further purification. Ethyl acetate (reagent grade) was purchased from J.T. Baker/ Avantor Performance Materials (Center Valley, PA, USA). Sodium tetraborate, sodium hydroxide, hydrochloric acid, dialysis membranes, molecular weight cut-off (MWCO) of 12,000-14,000, 98\% sulfuric acid, and $\mathrm{N}$ acetyl glycine were purchased from Fischer Scientific (Fair Lawn, NJ, USA).

\begin{tabular}{|c|c|c|c|}
\hline $\begin{array}{l}\text { Abbreviati } \\
\text { on }\end{array}$ & $\underline{\text { Name }}$ & $\underline{\text { CAS \# }}$ & $\underline{\text { Structure }}$ \\
\hline$\overline{4,4}$ '-MDI & $\begin{array}{l}\text { 4,4 Methylene } \\
\text { Diphenyl } \\
\text { Diisocyanate }\end{array}$ & $101-68-8$ & \\
\hline 2,4-TDI & $\begin{array}{l}\text { 2,4 Toluene } \\
\text { Diisocyanate }\end{array}$ & 584-84-9 & \\
\hline 1,6-HDI & $\begin{array}{l}1,6 \\
\text { Hexamethylen } \\
\text { e Diisocyanate }\end{array}$ & $822-06-0$ & \\
\hline
\end{tabular}

Figure 2.1: Chemical structures for the isocyanates conjugated to carrier proteins.

\subsection{METHODS}

\subsubsection{Preparation of dNCO-protein adducts}

MDI-HSA/Hb conjugations 
MDI-protein adducts were prepared as described previously ${ }^{55}$. Briefly, protein solutions were prepared in $0.1 \mathrm{M} \mathrm{PBS}(\mathrm{pH} 7.4)$ at $0.5 \mathrm{mg} / \mathrm{ml}$. MDI was dissolved in dry acetone at $1.8,9,18$, and $72 \mu \mathrm{g} / \mathrm{ml}$ for HSA conjugation and at $1.84,9.2,18.4$, and $73.6 \mu \mathrm{g} / \mathrm{ml}$ for $\mathrm{Hb}$ conjugation immediately before use. Each MDI solution was added at $34.5 \mu \mathrm{l}$ to $5 \mathrm{ml}$ of $0.5 \mathrm{mg} / \mathrm{ml}$ protein with mixing, resulting in MDI-protein molar ratios of 1:1, 5:1, 10:1, and 40:1. Samples were then incubated at room temperature (RT) for $1 \mathrm{~h}$ with vortexing. Following incubation, samples were dialyzed for $18 \mathrm{~h}$ against $4 \mathrm{~L}$ of distilled deionized water using 12,000 to 14,000 MWCO dialysis tubing (Sigma-Aldrich). The samples were stored at $20^{\circ} \mathrm{C}$ until analysis.

TDI-HSA/Hb conjugations

For preparation of TDI-protein adducts, protein solutions were prepared in 0.1 M PBS $(\mathrm{pH} 7.4$ ) at $0.5 \mathrm{mg} / \mathrm{ml} .42 .3 \mu \mathrm{l}$ of TDI were dissolved in $1 \mathrm{ml}$ dry acetone and diluted ten-fold to make stock solution for the 40:1 TDI: protein. Serial dilutions of TDI in acetone were prepared to make solutions for 10: 1, 5: 1 and 1: 1 TDI: protein. Each TDI solution $(50 \mu \mathrm{l})$ was added to $5 \mathrm{ml}$ of $0.5 \mathrm{mg} / \mathrm{ml}$ protein with mixing, resulting in TDI: protein molar ratios of $1: 1,5: 1,10: 1$, and 40:1. Samples were incubated and dialyzed as described in section 2.3.1 above.

\section{HDI-HSA/Hb conjugations}

For preparation of HDI-protein adducts, protein solutions were prepared in 0.1 M PBS (pH 7.4) at $0.5 \mathrm{mg} / \mathrm{ml}$. A $47.3 \mu \mathrm{l}$ aliquot of HDI was dissolved in $1 \mathrm{ml}$ dry acetone and diluted ten times to make stock solution for the 40:1 HDI: protein. Serial dilutions of HDI in acetone were prepared to make solutions for 10: 1, 5: 1 and 1: $1 \mathrm{HDI}$ : protein. 
$50 \mu \mathrm{L}$ of the HDI solution was added to $5 \mathrm{ml}$ of $0.5 \mathrm{mg} / \mathrm{ml}$ protein with mixing, resulting in $\mathrm{HDI} /$ protein molar ratios of 1:1, 5:1, 10:1, and 40:1. Samples were incubated and dialyzed as described previously.

\subsubsection{THP-1 MDI Conjugations}

THP-1 cell culture and MDI exposure

THP-1 monocytic cells (ATCC, Rockville, MD) were cultured in RPMI 1640 (Life

Technologies) containing 4mM L-glutamine, 25mM HEPES, 50 $\mu \mathrm{M}$ ß-mercaptoethanol, $10 \%$ FBS, and $1 \%$ antibiotic/antimycotic solution. After sufficient cell replication, the cells were harvested by centrifuging at $300 \mathrm{~g}$ for $10 \mathrm{~min}$. The RPMI culture media was discarded and the cell pellet washed two times with Hanks buffer (+Glucose, + calcium, + magnesium) and the cells were resuspended in the same buffer. Viability and cell count were determined before and after exposure to MDI and maintained above $75 \%$. Viability was measured using trypan blue. Fifteen million cells suspended in $2 \mathrm{ml}$ of Hanks buffer were exposed to MDI $5 \mu \mathrm{M}, 10 \mu \mathrm{M}, 25 \mu \mathrm{M}, 50 \mu \mathrm{M}$ and $100 \mu \mathrm{M}$ MDI prepared in $20 \mu \mathrm{L}$ of ethylene glycol dimethyl ether (EGDE). The MDI was added drop wise with vortexing and samples were incubated at $37^{\circ} \mathrm{C}$ and $5 \% \mathrm{CO}_{2}(\operatorname{model} 370$ Steri-Cycle $\mathrm{CO}_{2}$ incubator, Forma Scientific Inc., Marietta, $\mathrm{OH}$ ) for $4 \mathrm{hrs.} \mathrm{Cells} \mathrm{were}$ spun down to remove the incubation media (Hanks buffer) and washed two times with Hanks buffer. Cells were stored as a pellet at $-20^{\circ} \mathrm{C}$ until further analysis. 
Effect of exposure times on THP-1-MDI conjugations

The effect of exposure time on the extent of conjugation of THP-1 cells was studied by exposing 15 million cells in a total volume of 2 ml Hanks buffer to $100 \mu \mathrm{M}$ MDI

prepared in EGDE for different time durations (30 min, $1 \mathrm{hr}, 2 \mathrm{hr}$, and $4 \mathrm{hr}$ ). MDI was added drop wise with vortexing and samples were incubated at $37^{\circ} \mathrm{C}$ and $5 \% \mathrm{CO}_{2}$. Samples were processed post exposure as described previously.

\subsubsection{THP-1 exposure controls}

Different control experiments were performed to confirm whether MDI crosses cell membranes and react with both membrane and intracellular proteins.

\section{THP-1, Cytochalasin D and MDI controls}

Cytochalasin D is a chemical that binds actin filaments and inhibits active uptake of substances into cells. THP-1 cells were incubated with $10 \mu \mathrm{M}$ cytochalasin D for $1 \mathrm{hr}$ and exposed to $50 \mu \mathrm{M}$ MDI for 4 hours. Cells were processed as previously described.

\section{THP-1 and MDA}

THP-1 cells were exposed to $100 \mu \mathrm{M}$ MDA prepared in EGDE. This was performed to assess the effectiveness of the washing process to get rid of any MDA that is not conjugated to proteins. After incubation, samples were processed as previously described. 
THP-1 and EGDE

The effect of the organic solvent used for conjugation on cell viability was determined by co-incubation of THP- 1 cells with $1 \%$ EGDE for $4 \mathrm{hr}$ at $37{ }^{\circ} \mathrm{C}$ and $5 \% \mathrm{CO}_{2}$. After incubation, cell count and viability were measured. Cells were processed as described previously.

\subsubsection{Protein estimation}

Two approaches were used to extract proteins from MDI-exposed THP-1 cells, differential centrifugation and use of protein extraction kits. Differential centrifugation at $300 \mathrm{~g}$ separates the membrane fraction (debri) from the cytoplasm fraction (supernatant). Membrane and cytoplasm protein extraction kits (Fischer scientific) were also used to selectively extract proteins from the membrane and cytoplasm fractions. Protein determinations were performed on the conjugates by measuring absorbance at $280 \mathrm{~nm}$ on a nano-drop spectrophotometer.

\subsubsection{The TNBS assay}

The TNBS reagent assesses, primarily, chemical adduction with primary amines of amino acids ${ }^{56,57}$ on the surface of proteins. TNBS produces an absorbance shift at 420 $\mathrm{nm}$ upon binding to a primary amine. The trinitrobenzene sulfonic acid (TNBS) assay was performed on HSA and MDI-HSA conjugates. HSA and HSA conjugates were diluted in $0.1 \mathrm{M}$ sodium tetraborate $(\mathrm{pH} 9.3)$. TNBS $(5 \%, \mathrm{w} / \mathrm{v})$ was diluted 1:5.48 with $0.1 \mathrm{M}$ borate buffer. To $500 \mu \mathrm{l}$ of samples, $12.5 \mu \mathrm{l}$ of TNBS was added, mixed well, 
and left to react for $30 \mathrm{~min}$. Absorbance at $420 \mathrm{~nm}$ was measured on a Beckman Coulter spectrophotometer (model DU 800, Beckman Coulter, Somerset, NJ, USA). Hb has a strong absorbance at $420 \mathrm{~nm}$ that prevents measurement of primary amine content by TNBS.

\subsubsection{Hydrolysis and extraction}

dNCO-protein conjugates

Diisocyanate conjugated proteins were hydrolyzed by incubating in $3 \mathrm{M} \mathrm{H}_{2} \mathrm{SO}_{4}$ at 100 ${ }^{\circ} \mathrm{C}$ for $16 \mathrm{hr}$. MDA, TDA or HDA spiked proteins were run in parallel as external calibration standards to the respective dNCO adducted proteins. Following hydrolysis, samples and standards were cooled to room temperature and $5 \mathrm{~mL}$ of saturated sodium hydroxide added. The samples were vortexed and incubated in an ice bath for 10 minutes. $6 \mathrm{~mL}$ of organic solvent, ethyl acetate (for MDI) or dichloromethane (for TDI and HDI) were added to the samples, vortexed for $1 \mathrm{~min}$ and left standing at room temperature for $1 \mathrm{hr}$. A $4 \mathrm{~mL}$ portion of the organic solvent was then collected and evaporated to $1 \mathrm{~mL}$ at $40{ }^{\circ} \mathrm{C}$ under $\mathrm{N}_{2}$. To the organic solvent, $500 \mu \mathrm{L}$ of $0.5 \% \mathrm{H}_{2} \mathrm{SO}_{4}$ were added and vortexed for $1 \mathrm{~min}$. The sample was vortexed for an additional 10 minutes and left standing for 10 minutes. $400 \mu \mathrm{L}$ of the $0.5 \% \mathrm{H}_{2} \mathrm{SO}_{4}$ were collected for derivatization.

\subsubsection{Derivatization and HPLC analysis}

To derivatize the extracted diamines for HPLC analysis, $250 \mu 1$ of saturated borate buffer ( $\mathrm{pH} 8.5$ ) and $450 \mu \mathrm{l}$ of acetonitrile were added to $250 \mu \mathrm{l}$ of $0.5 \% \mathrm{H}_{2} \mathrm{SO}_{4}$ extract 
with MDA, TDA or HDA. This was vortexed for $1 \mathrm{~min}$, and $50 \mu 1$ of $14.4 \mathrm{mg} / \mathrm{mL}$ fluorescamine in acetonitrile were added. This was vortexed for $1 \mathrm{~min}$ before $100 \mu \mathrm{l}$ of the resultant fluorescent solution was injected onto a Supelco LC-SI C18 column (25 $\mathrm{cm}$ x $4.6 \mathrm{~mm}, 5 \mu \mathrm{m}$, Supelco, Bellefonte, PA, USA). Samples and standards were analyzed on a Shimadzu Prominence HPLC system (Shimadzu, Columbia, MD, USA).

\subsubsection{Delineation of MDI and TDI specific binding sites on $\mathrm{Hb}$}

Trypsin digestion of hemoglobin samples

MDI and TDI conjugation sites of $\mathrm{Hb}$ were analyzed by ultra-performance liquid chromatography quadrupole time-of-flight mass spectrometry (UPLC-qTOF MS). In preparation for mass spec analysis, $200 \mu \mathrm{l}$ aliquots of $\mathrm{MDI}-\mathrm{Hb}$ and TDI-Hb samples were treated with tributylphosphine for $30 \mathrm{~min}$ at RT to reduce the disulfide bonds. The samples were alkylated with iodoacetamide for $1 \mathrm{~h}$ at room temperature. Alkylation was quenched by further addition of tributylphosphine for $15 \mathrm{~min}$ at room temperature. Porcine trypsin in $25 \mathrm{mM} \mathrm{NH}_{4} \mathrm{HCO}_{3}$ was then added at a 40:1 (protein/trypsin) ratio. Samples were incubated overnight at $37^{\circ} \mathrm{C}$.

\section{Ultra Performance Liquid Chromatography (UPLC)}

Tryptic peptides of $\mathrm{Hb}$, TDI-Hb and MDI-Hb were separated on a Waters nanoACQUITY UPLC system (Waters, Milford, MA, USA). Aliquots ( $1 \mu \mathrm{l})$ of the digest mixture were injected and trapped/desalted on a 5- $\mu \mathrm{m}$ Symmetry C18 trapping column $(180 \mu \mathrm{m}$ x $20 \mathrm{~mm})$ with 99.5/0.5 A/B (A: $0.1 \%$ formic acid; B: $0.1 \%$ formic 
acid in acetonitrile) at a flow rate of $15 \mu \mathrm{l} / \mathrm{min}$ for $1 \mathrm{~min}$. Separation was performed on a $1.7-\mu \mathrm{m}$ BEH130 C18 analytical column $(100 \mu \mathrm{m} \times 100 \mathrm{~mm})$ using gradient elution at a flow rate of $400 \mathrm{nl} / \mathrm{min}$ and a gradient of $99: 1$ to $60: 40 \mathrm{~A} / \mathrm{B}$ over $90 \mathrm{~min}$.

\section{MS/MS of Hb peptides}

The eluent from the UPLC system was directed to the nanoelectrospray source of a Waters SYNAPT MS qTOF mass spectrometer. Positive ion nanoelectrospray was performed using $10 \mu \mathrm{m}$ Pico-Tip (Waters) emitters held at a potential of $+3.5 \mathrm{kV}$. The cone voltage was held constant at $+40 \mathrm{~V}$ for all experiments. Dry nitrogen desolvation gas was supplied to the instrument via a nitrogen generator (NitroFlowLab, Parker Hannifin, Haverhill, MA, USA). [Glu]1 Fibrinopeptide B (100 fmol/ $\mu 1$ in 75:25 A/B) was supplied to an orthogonal reference probe, and the $[\mathrm{M}+2 \mathrm{H}]^{2+}$ ion $(\mathrm{m} / \mathrm{z} 785.84265 \mathrm{u})$ was measured as an external calibrant at 30-s intervals. Ultra-high purity (UHP) argon

was used as collision gas. Spectra were acquired in an "MSe' fashion ${ }^{58}$. Alternating 1 sec mass spectra were acquired. The collision energy was set to $6 \mathrm{eV}$ (1 sec low energy scan) and a 15- to 30-eV ramp (1 sec high energy scan).

\section{Data analysis for MDI binding sites on $\mathrm{Hb}$}

Data were analyzed with BioPharmaLynx version 1.2 (Waters), a software program for analysis of peptide mass maps and identification of sites of modification on known protein sequences. Default peptide mass map analysis criteria of $30 \mathrm{ppm}$ mass error in both low- and high-collision energy mode were specified. Trypsin was specified as the 
digestion enzyme, and two missed cleavages were allowed. Identification of an isocyanate binding site proceeded via a rigorous procedure that involved the following steps: (i) observing a potential peptide-dNCO conjugation product with less than 30 ppm $\mathrm{m} / \mathrm{Dm}$ mass error in the analyte peptide mass map, (ii) comparing analyte and control peptide mass map from unmodified $\mathrm{Hb}$ showing that observed $\mathrm{m} / \mathrm{z}$ and chromatographic retention time are unique to analyte, and (iii) observing MS/MS data containing bn- and yn-type ions consistent with the assigned sequence and modifier.

\subsubsection{Identification of MDI bound proteins}

SDS gel electrophoresis of the cytoplasm and membrane fractions were run and protein bands with detectable MDA were excised. Trypsin digestion was performed on the resultant proteins and the peptides analyzed by mass spectrometry to identify the proteins in the gel bands as described previously.

\subsubsection{Sodium dodecyl sulfate (SDS) polyacrylamide gel electrophoresis (PAGE) dNCO-protein gels}

For denaturing gels, proteins and dNCO-protein conjugates were mixed with $950 \mu \mathrm{l}$ of Laemmli sample buffer and $50 \mu 1$ of 2- mercaptoethanol. Sodium dodecyl sulfate (SDS) acrylamide gels (8\% and $12 \%)$ were cast. Precast gradient gels (4-20\%) were obtained from Bio-Rad (Hercules, CA, USA). Samples were run on $8 \%, 12 \%$, and $4 \%-20 \%$ gradient polyacrylamide gels. Following electrophoretic separation of proteins, the gels were stained with imperial protein stain (Pierce, Rockford, IL, USA) and destained with 
water. Unmodified protein and Bio-Rad prestained molecular weight markers were used for relative molecular weight determination. For native gels, unmodified protein and dNCO-protein samples were mixed with native sample buffer from Bio-Rad and run on $8 \%$ native gels in parallel with unstained protein markers from Life Technologies (Carlsbad, CA, USA). Gels were stained and destained as described previously ${ }^{59}$.

\subsubsection{Enzyme-linked immunosorbent (ELISA) assays}

Immunoassay for percentage of number of HSA conjugated.

Binding of a murine IgM 15D4 mAb to MDI-conjugated HSA was analyzed using a sandwich ELISA ${ }^{60,61}$. Here, 96-well plates (Corning, Corning, NY, USA) were coated with $4 \mu \mathrm{g} / \mathrm{ml}$ Affini-Pure goat anti-mouse IgM and $\mu$ chain-specific IgG (Jackson ImmunoResearch Laboratories, West Grove, PA, USA) overnight at $4^{\circ} \mathrm{C}$. After washing three times with PBST (PBS and Tween 20), wells were incubated on a shaker for $1 \mathrm{~h}$ with $2 \mu \mathrm{g} / \mathrm{ml} 15 \mathrm{D} 4 \mathrm{mAb}$ at room temperature. The plates were then blocked with 3\% skim milk/PBS-Tween 20 (SMPBST) for $1 \mathrm{~h}$ at $37^{\circ} \mathrm{C}$. Duplicate MDI-HSA conjugates were then added to the blocked plates at a concentration of $25 \mu \mathrm{g} / \mathrm{ml}$ and incubated for $1 \mathrm{~h}$ at $37^{\circ} \mathrm{C}$. Plates were then washed three times with PBST and incubated for $1 \mathrm{~h}$ at $37^{\circ} \mathrm{C}$ with biotin-conjugated affinity-purified rabbit anti-HSA (Rockland, Gilbertsville, PA, USA) diluted 1:5000 (v/v) in SMPBST. The plates were then washed three times with PBST and incubated for $1 \mathrm{~h}$ at $37^{\circ} \mathrm{C}$ with alkaline phosphatase-conjugated streptavidin (Jackson Immuno- Research Laboratories) diluted 1:5000 (v/v) in SMPBST. Following incubation, the plates were washed with PBST and 
binding of the 15D4 mAb to the conjugates was visualized using $0.5 \mathrm{mg} / \mathrm{mL}$ nitrophenyl phosphate (Sigma-Aldrich) in alkaline phosphatase substrate. The optical density was determined at $405 \mathrm{~nm}$ after $30 \mathrm{~min}$.

\section{ELISA for TDI-HSA and TDI-Hb}

Binding of an IgG, 60G2 monoclonal antibody (mAb) to TDI-conjugated $\mathrm{HSA}$ and $\mathrm{Hb}$ was analyzed using an indirect enzyme-linked immunosorbent assay (ELISA) ${ }^{61-63} \cdot 96-$ well plates (Corning, Corning, NY, USA) were coated with TDI-protein conjugates overnight at $4^{\circ}$ C. After washing three times with PBST (PBS and Tween 20), wells were incubated on a shaker for $1 \mathrm{~h}$ with two $\mu \mathrm{g} / \mathrm{ml} 60 \mathrm{G} 2 \mathrm{mAb}$ at RT. The plates were then blocked with 3\% skim milk/PBS-Tween 20 (SMPBST) for $1 \mathrm{~h}$ at $37^{\circ} \mathrm{C}$. Plates were then washed three times with PBST and incubated for $1 \mathrm{~h}$ at $37^{\circ} \mathrm{C}$ with alkaline

phosphatase conjugated affini-Pure goat, anti-mouse IgG(H+L) (Promega, Cat \# S3721 USA) diluted 1:5000 (v/v) in SMPBST. Following incubation, the plates were washed 3 times with PBST and binding of the $60 \mathrm{G} 2 \mathrm{mAb}$ to the conjugates was visualized using $0.5 \mathrm{mg} / \mathrm{ml}$ p-nitrophenyl phosphate (Sigma-Aldrich) in alkaline phosphatase substrate. The optical density was determined at $405 \mathrm{~nm}$ after $30 \mathrm{~min}$. 


\section{CHAPTER 3}

\section{DEVELOPMENT OF AN HPLC METHOD FOR QUANTIFICATION OF DIISOCYANATES CONJUGATION TO HSA AND Hb.}

\subsection{INTRODUCTION}

Protein haptenation by dNCOs such as MDI, TDI and HDI is thought to be an important step in the development of diisocyanate-specific allergic sensitization. The fate of the $\mathrm{dNCO}$ in the body and the ultimate protein adduct responsible for immunological sensitization currently remain unknown ${ }^{32}$. Apart from directly reacting with proteins at the site of exposure, diisocyanates can react with glutathione or protein thiols, forming labile thiocarbamate adducts that may possibly be transported to sites distal to the site of exposure. It is not known whether the antigenicity of proteins adducted by isocyanates regenerated from thiocarbamates is different from that via direct haptenation. Diisocyanate-conjugated proteins are used to screen for dNCO-specific antibodies in workers' sera and the assay is commonly used as a tool in $\mathrm{dNCO}$ asthma diagnosis, however, the assay has been reported to have poor sensitivity in confirmed diisocyanate-asthma cases ${ }^{64}$. Diisocyanate-haptenated albumins used for the screening of dNCO-specific antibodies in workers' sera are often poorly characterized. Recently, the need to develop standardized immunoassays using a consistent, well-characterized dNCO-haptenated protein to screen for the presence of diisocyanate-specific IgE and IgG from workers' sera has been recognized and emphasized ${ }^{65,66}$. Synthetic methods have been reported for amino acid conjugation 
using thiocarbamates ${ }^{67}$, which may possibly find utility in haptenation of whole proteins for specific antibody detection.

Isocyanates can react with the following amino acids under physiological conditions: the $\alpha$-amino group of all $\mathrm{N}$-terminal amino acids, the sulfhydryl group of cysteine, the hydroxyl groups of tyrosine and especially the $\varepsilon$-amino group of lysine and the imidazole ring of histidine ${ }^{68,69}$. Figure 3.1 shows the structures of the four amino acids (excluding those where the $\mathrm{N}$-terminal has been reported bound) that have been observed to react with diisocyanates. Isocyanate-specific adducts with the N-terminal valine of hemoglobin with MDI have been quantified in rats ${ }^{70}$. Sepai et. al. found hemoglobin adducts correlated with the administered dose of $\mathrm{MDI}^{71}$ while Sabbioni et. al. demonstrated that MDA also binds to hemoglobin (through a metabolic intermediate) ${ }^{72}$.
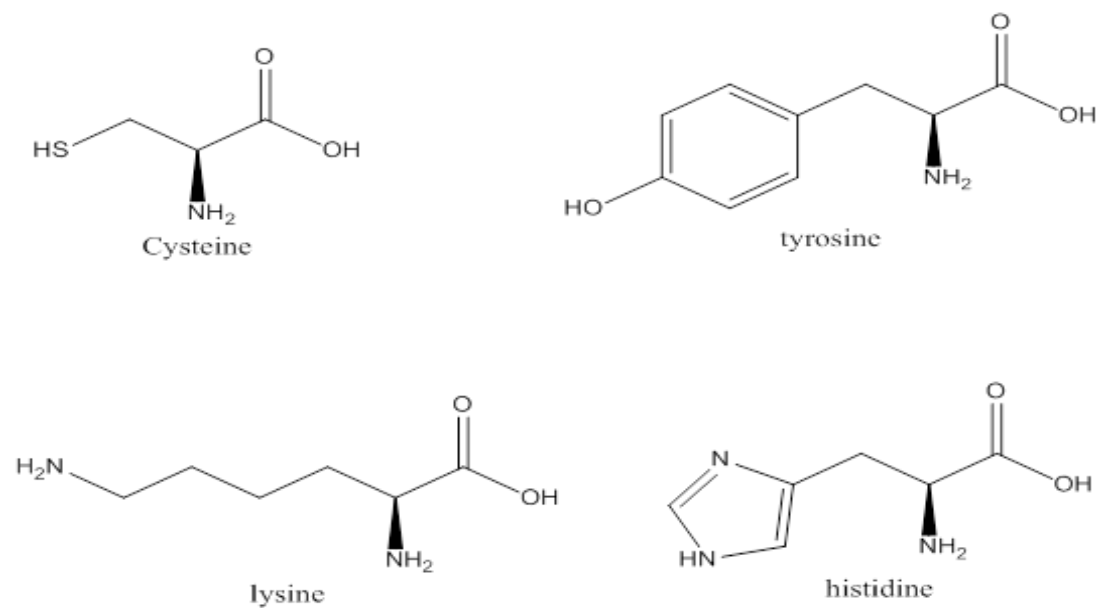

Figure 3.1: Structures of the amino acids that have been found to react with isocyanates. 
There are several HPLC and GC mass spectrometry methods that have been developed and used to characterize $\mathrm{dNCO}$-protein conjugates for biomonitoring of $\mathrm{dNCO}$ exposure $^{73,74}$. The TNBS assay has also been used for characterization of dNCOprotein conjugates and results have often been over-interpreted ${ }^{75}$. Gel electrophoresis and Western blot analyses provide more qualitative assessment of the $\mathrm{dNCO}$ conjugates, but are generally of poor resolution and at best can be semi-quantitative with respect to degree of haptenation.

In light of these limitations, it was important to develop a sensitive and simple method of determining dNCO binding to proteins. The method would be useful for characterization of dNCO conjugation to proteins.

\subsection{The HPLC method.}

The HPLC system used in this study was a reversed phase with the C-18 R-group of the siloxane coating.

\subsubsection{Hydrolysis}

The HPLC method is based on the hydrolysis of dNCO-protein conjugates under high acid concentrations at elevated temperature. This generates a complex mixture of the dNCO hydrolysis products [methylene dianiline (MDA), toluene diamine (TDA) and hexamethylene diamine (HDA)], amino acids and several hydrolysis products from protein(s). Figure 3.2 below is a simplified scheme of the hydrolysis of an MDI- 
protein conjugate with the protein conjugated on the lysine residue to generate MDA and amino acids.

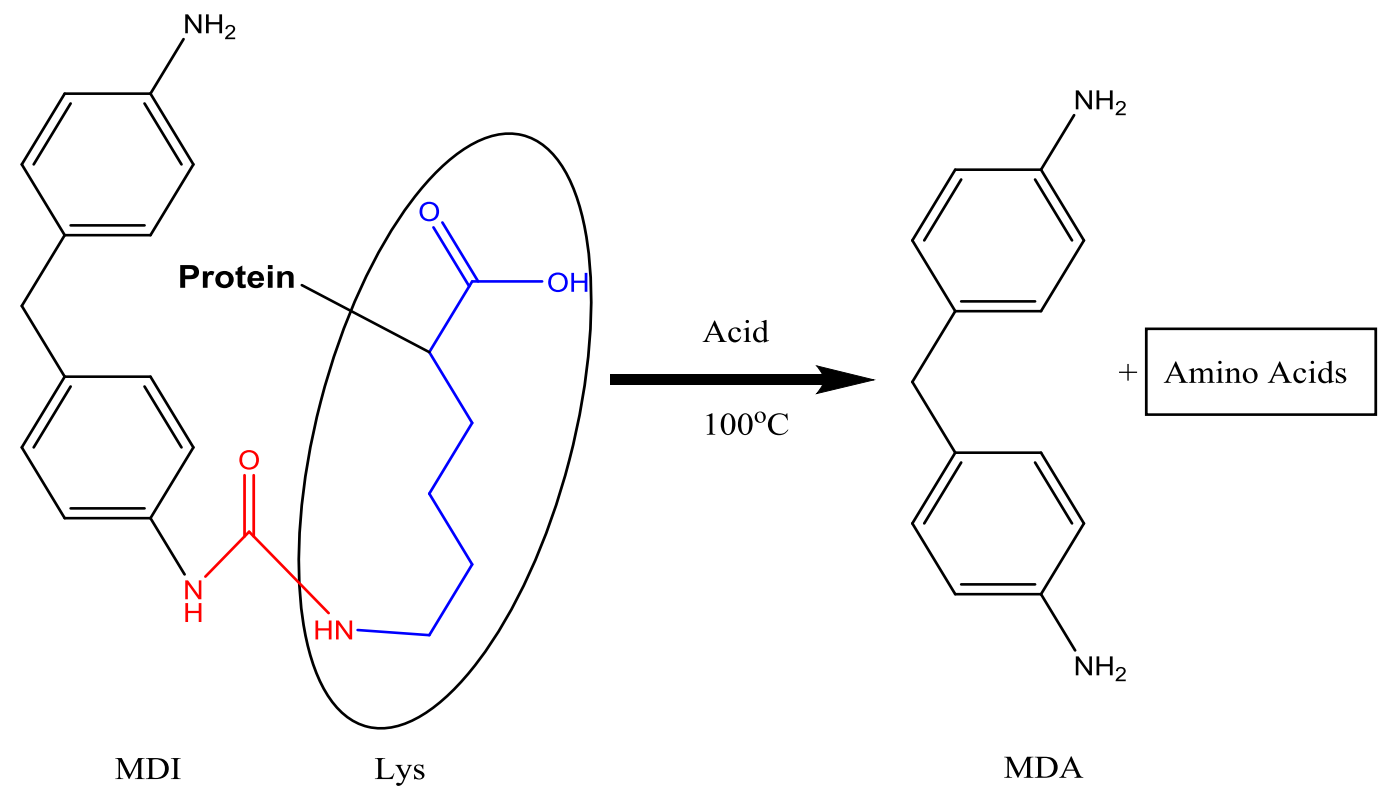

Figure 3.2: The hydrolysis of MDI-protein conjugates in acid and high temperature to give $M D A$

\subsubsection{Extraction}

The dNCO diamine hydrolysis product is selectively extracted from the complex hydrolysis mixture. After hydrolysis, the diamine hydrolysis product in acid is more soluble in aqueous media. Addition of saturated sodium hydroxide deprotonates the diamine, making it less soluble in aqueous environments. Subsequent addition of a water immiscible organic solvent such as dichloromethane or ethyl acetate results in preferential partitioning of the diamine into the organic solvent thus separating the diamine from potential interfering substances. 


\subsubsection{Derivatization}

The diamines from the acid hydrolysis of diisocyanate-protein conjugates are not conventional fluorophores but can be derivatized to highly fluorescent complexes. Fluorescamine was used in this particular work to derivatize the diamine hydrolysis products. Fluorescamine is a reagent for the detection of primary amines in the picomole range ${ }^{76}$. Its reaction with amines is almost instantaneous at room temperature in aqueous media. The products are highly fluorescent, whereas the reagent and its degradation products are non-fluorescent ${ }^{77}$. The reaction of a primary amine with fluorescamine is shown in Figure 3.3 below.

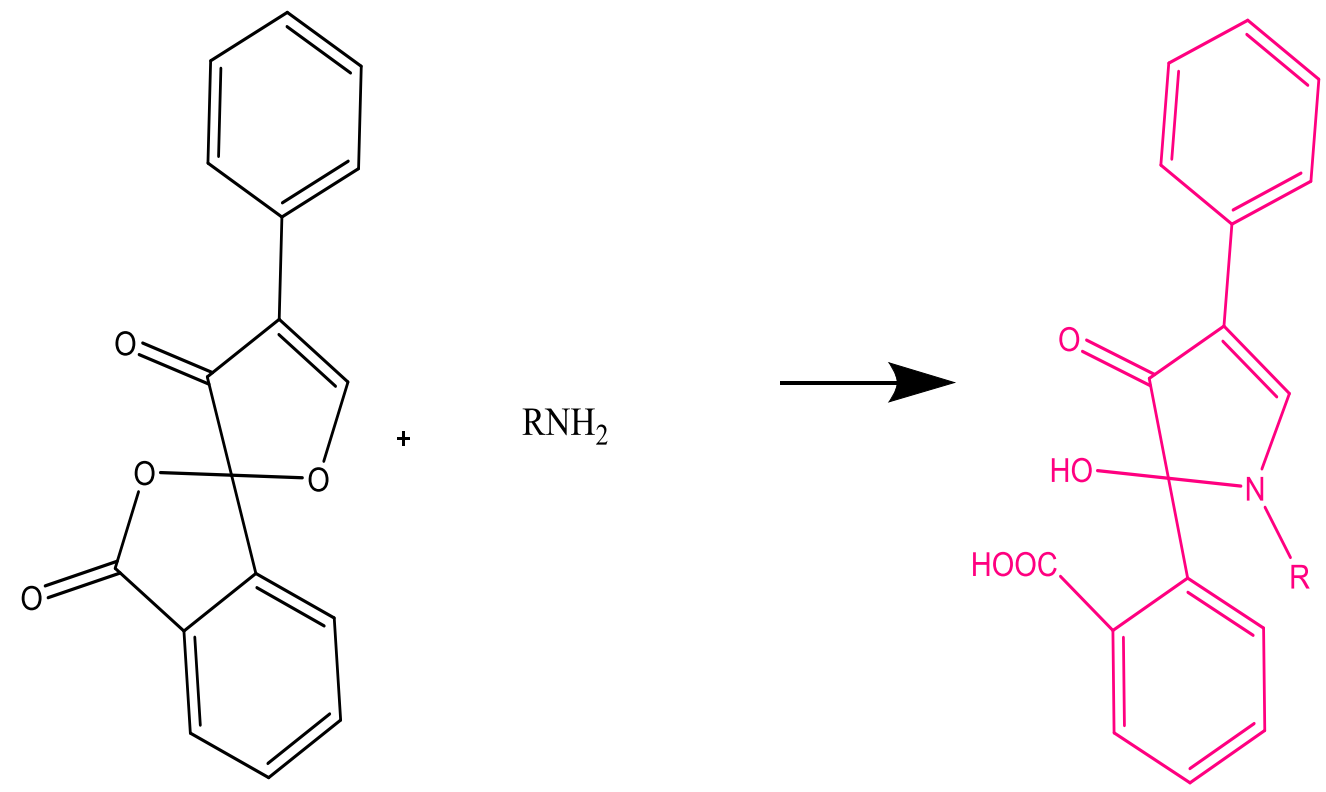

Figure 3.3: The reaction of a primary amine with fluorescamine to form the fluorescent complex 


\subsection{RESULTS AND DISCUSSION.}

\subsubsection{Optimization of the derivatization reaction}

The diamine-fluorescamine derivatization reaction was studied under different $\mathrm{pH}$ conditions, in different buffer systems, and in different proportions of acetonitrile to the buffer system. Fluorescence intensity was measured using a conventional flourometer. Toker SE et $\mathrm{al}^{78}$ reported an HPLC method with fluorescence detection in which they performed the fluorescamine derivatization of memantine extracted from human plasma. The memantine residue was derivatized by reacting with 320 molar excess fluorescamine in $500 \mathrm{~mL}$ of borate buffer (pH 8.5), $250 \mathrm{~mL}$ of fluorescamine reagent solution and $250 \mathrm{~mL}$ of acetonitrile. Although memantine has a single primary amine group, the conditions they employed were the basis for this optimization process.

\subsubsection{Determination of the optimum solvent system for derivatization}

The solvent system that produced the best fluorescence was evaluated by derivatizing MDA in different buffers with different proportions of buffer: acetonitrile and at different pHs. Table 3.1 below shows the fluorescence intensities obtained when 1000 $\mathrm{ng} / \mathrm{ml}$ MDA was derivatized in $0.16 \mathrm{M}$ boric acid at $\mathrm{pH} 9.6$ at different ratios of acetonitrile to buffer. The highest fluorescence intensity was obtained when derivatization was performed in a 50\% acetonitrile-buffer mixture. Table 3.2 shows fluorescence intensities obtained when the same experiment was performed in saturated borate buffer at $\mathrm{pH} 8.45$ at different ratios of acetonitrile: buffer. In saturated 
borate buffer, the most intense fluorescence was observed at $66.7 \%$ acetonitrile:

buffer.

Table 3.1: Fluorescence results obtained with $0.16 \mathrm{M}$ boric acid (sodium) buffer solution at $\mathrm{pH} 9.6$

\begin{tabular}{|c|c|c|}
\hline $\begin{array}{c}\text { Derivatizing solution( \% } \\
\text { ACN in Boric acid buffer) }\end{array}$ & $\begin{array}{c}\text { Fluorescence Intensity with } \\
\mathbf{1 0 0 0} \text { ng/ml MDA* }\end{array}$ & No MDA*(Blank) \\
\hline $50 \%$ & 435.946 & 158.195 \\
\hline $66.7 \%$ & 272.747 & 158.195 \\
\hline $80 \%$ & 280.544 & 158.195 \\
\hline $87 \%$ & 287.509 & 158.195 \\
\hline $100 \%$ & 276.352 & 158.195 \\
\hline
\end{tabular}

*- measurements performed on a flourometer without HPLC separation

Table 3.2: Fluorescence results obtained with saturated borate buffer $\mathrm{pH} 8.45$

\begin{tabular}{|c|c|c|}
\hline $\begin{array}{c}\text { Derivatizing solution ( \% } \\
\text { ACN in Borate Buffer Added) }\end{array}$ & $\begin{array}{c}\text { Fluorescence Intensity } \\
\text { with } \mathbf{1 0 0 0} \text { ng/ml MDA* }\end{array}$ & $\begin{array}{c}\text { No } \\
\text { MDA*(Blank) }\end{array}$ \\
\hline $50 \%$ & 491.236 & 156.618 \\
\hline $66.7 \%$ & 520.225 & 156.618 \\
\hline $80 \%$ & 277.355 & 156.618 \\
\hline $87 \%$ & 280.663 & 156.618 \\
\hline $100 \%$ & 264.213 & 156.618 \\
\hline
\end{tabular}

*-measurements performed on a flourometer without HPLC separation.

Comparison of the optimum fluorescence intensities for the two buffers. Saturated borate buffer had better fluorescence intensities at both $50 \%$ and $66.7 \%$ acetonitrile: buffer compared to $0.16 \mathrm{M}$ boric acid. For saturated borate buffer alone, the best fluorescence intensity was obtained at $66.7 \%$ acetonitrile: buffer. It was therefore determined that the optimal conditions were to derivatize MDA in $66.7 \%$ acetonitrile: saturated borate buffer at $\mathrm{pH} 8.45$ with 320 -fold molar excess fluorescamine. 


\subsubsection{HPLC analysis of the derivatized MDA}

After optimizing the derivatization reaction, MDA was dissolved in $0.5 \% \mathrm{H}_{2} \mathrm{SO}_{4}$ and derivatized as described previously. The resultant fluorescent complex was run on the HPLC measured in the fluorometer at an excitation $\lambda=410 \mathrm{~nm}$ and emission $\lambda=510 \mathrm{~nm}$.

The following parameters were used on the HPLC to run the MDA standards.

\section{Parameters}

1. Table 3.3: Gradient elution

\begin{tabular}{|l|l|l|l|}
\hline Time & Module & Action & ACN Value (\%) \\
\hline 0.01 & Controller & Start & \\
\hline 0.02 & Pumps & Pump B conc & 10.0 \\
\hline 13.00 & Pumps & Pump B conc & 50.0 \\
\hline 18.00 & Pumps & Pump B conc & 50.0 \\
\hline 19.00 & Pumps & Pump B conc & 10.0 \\
\hline 20.00 & Controller & Stop & \\
\hline
\end{tabular}

NB: Pump B is acetonitrile and pump A is water.

2. Excitation wavelength: $410 \mathrm{~nm}$, Emission wavelength: $510 \mathrm{~nm}$

3. Flow rate $1 \mathrm{~mL} / \mathrm{min}$

4. Column C18, $25 \mathrm{~cm}$ x $4.4 \mathrm{~mm}, 5 \mu \mathrm{m}$ particle size with guard column.

Figure 3.4 is an overlay of derivatized MDA chromatograms from 1-100 ng/ml. A negative solvent control that had no MDA was also derivatized to evaluate the extent of background fluorescence. 


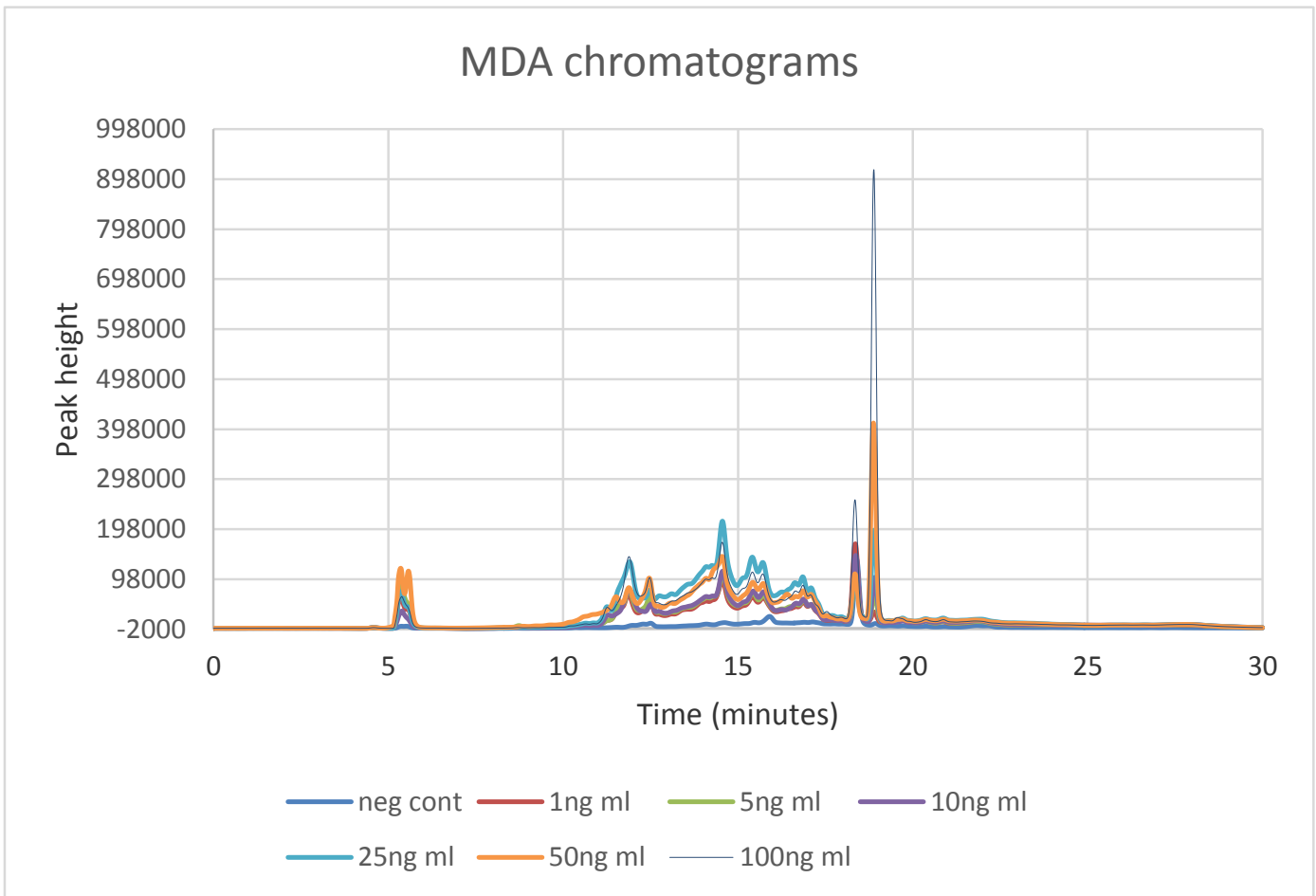

Figure 3.4: MDA chromatograms from HPLC analysis. The retention time for the MDA peak was 18.9 minutes.

The MDA peak size increased in a dose-dependent manner with increasing concentration of MDA. Figure 3.5 was obtained by blowing out the region from 17 to 20 minutes to clearly visualize the MDA peak. The peak observed at 18.36 minutes is not due to MDA as this peak was present in the negative control and not MDA dosedependent. This peak could be due to impurities in the MDA or the fluorescamine. 


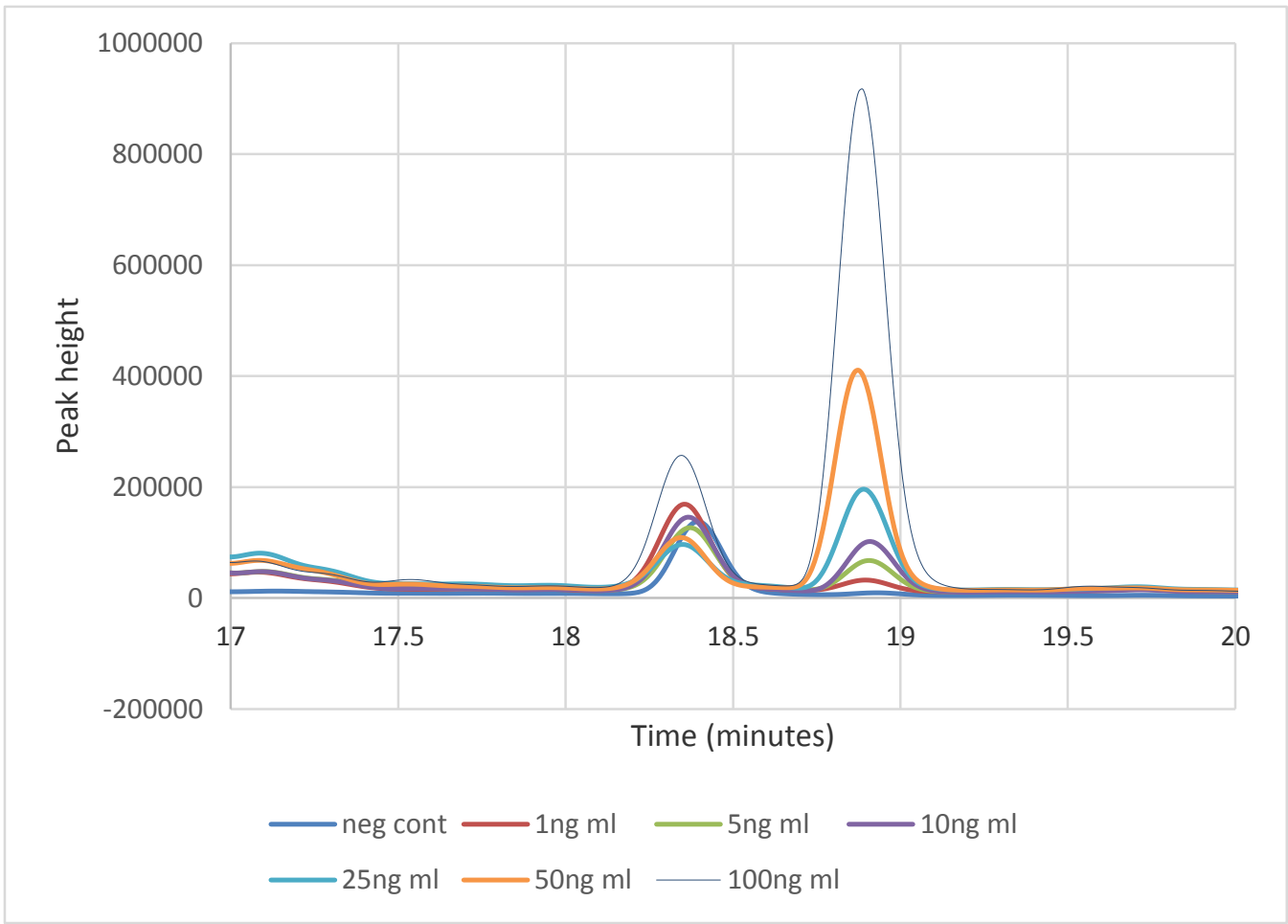

Figure 3.5: MDA chromatograms from HPLC analysis from 17-20 minutes. The retention time for the MDA peak was 18.9 minutes.

\subsubsection{Extending the derivatization to TDA and HDA}

The derivatization reaction was applied to 2, 4-TDA and HDA to evaluate the utility of the method to other di isocyanates. 2,4-TDA, HDA standards were derivatized as described previously, and the resultant fluorescent complexes analyzed by HPLC. TDA had a retention time of $16.7 \mathrm{~min}$ and HDA had a retention time of $14.2 \mathrm{~min}$.

\subsubsection{Direct derivatization calibration curves}

To evaluate the capability of the method for quantification of MDA, TDA and HDA, different concentrations of these standards were prepared in $0.5 \% \mathrm{H}_{2} \mathrm{SO}_{4}$, derivatized as previously described and analyzed by HPLC. The diamine-fluorescamine peaks 
were integrated using the EZstart software and the peak area was plotted against the diamine concentration.

Figure 3.6 below is a calibration curve obtained when different concentrations of MDA were analyzed by HPLC. There is a strong linear correlation between the peak area and the MDA standard concentration with an r-square value of 0.9986 . The limit of detection was $1 \mathrm{ng} / \mathrm{mL}$ MDA with an injection volume of $100 \mu \mathrm{L}$.

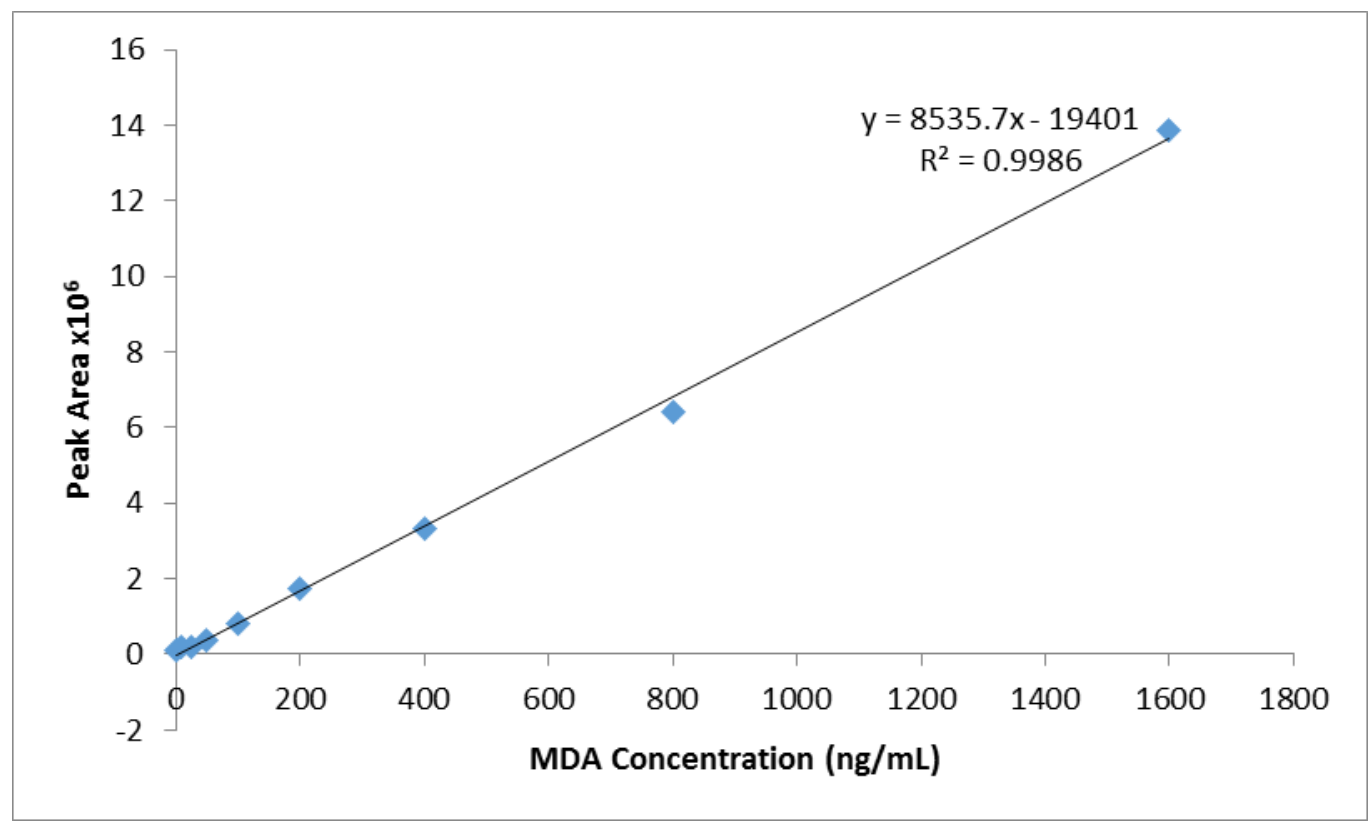

Figure 3.6: Calibration curve obtained from the direct derivatization of MDA with fluorescamine

When the same experiment was performed with 2, 4-TDA and HDA, the correlations were good with correlation coefficients of 0.9947 and 0.9992 for 2, 4-TDA and HDA respectively. It is therefore possible to quantify the amount of MDA, 2, 4-TDA or HDA in a sample using this HPLC method. 


\subsubsection{Optimization of the extraction}

After hydrolysis of the diisocyanate-protein conjugate, the diamine hydrolysis product was selectively extracted prior to derivatization. Toluene, dichloromethane, and ethyl acetate extraction solvents were compared. MDA was spiked into $0.5 \mathrm{mg} / \mathrm{ml}$ of HSA and $\mathrm{Hb}$ solutions, acid hydrolyzed, alkalinized, and extracted using the three solvents. No MDA was detected when toluene was used for extraction. Solubility checks indicated that MDA is barely soluble in toluene making toluene a poor choice for extraction of MDA. Dichloromethane (DCM) and ethyl acetate (EA) were therefore employed for extraction of MDA, 2, 4-TDA and HDA and extraction efficiencies of the two solvents were tested by using each solvent to extract a 100ng/ml MDA, 2, 4TDA and HDA. Table 3.5 shows the extraction efficiencies of the two solvents calculated by dividing the peak area of $100 \mathrm{ng} / \mathrm{ml}$ MDA, 2,4-TDA and HDA extracted using DCM and EA by the peak area of directly derivatized $100 \mathrm{ng} / \mathrm{ml} \mathrm{MDA,} \mathrm{2,} \mathrm{4-}$ TDA and HDA. Table 3.6 shows solvents that were chosen for extraction of each diamine based on superior extraction efficiencies.

Table 3.4: Extraction efficiencies obtained for DCM and EA

\begin{tabular}{|l|l|l|l|}
\hline Solvent & $\begin{array}{l}\text { Ext efficiency (\%) } \\
\text { for MDA }\end{array}$ & $\begin{array}{l}\text { Ext efficiency (\%) } \\
\text { for TDA }\end{array}$ & $\begin{array}{l}\text { Ext efficiency (\%) } \\
\text { for HDA }\end{array}$ \\
\hline DCM 1 & $36.2 \pm 17.0$ (s.d.) & $97.4 \pm 3.2$ (s.d.) & $95.7 \pm 3.9$ (s.d.) \\
\hline EA 1 & $96.2 \pm 4.3$ (s.d.) & $88.3 \pm 4.8$ (s.d.) & $89.2 \pm 4.5$ (s.d.) \\
\hline
\end{tabular}


Table 3.5: Extraction solvents chosen for each diamine

\begin{tabular}{|l|l|}
\hline Diamine & Solvent with best extraction efficiency \\
\hline MDA & Ethyl acetate \\
\hline $2,4-$ TDA & Dichloromethane \\
\hline HDA & Dichloromethane \\
\hline
\end{tabular}

\subsubsection{Back extraction.}

For most methods reported in literature, the MDA, TDA or HDA organic extraction solvent was dried completely under nitrogen and the resultant residue reconstituted into an aqueous solvent and derivatized ${ }^{79}$. Evaporation under nitrogen of ethyl acetate to dryness and subsequent reconstitution into $0.5 \% \mathrm{H}_{2} \mathrm{SO}_{4}$ produced significant and inconsistent loss of MDA. However, partial evaporation to reduce the volume of ethyl acetate and subsequent back extraction into $400 \mu \mathrm{L}$ of $0.5 \% \mathrm{H}_{2} \mathrm{SO}_{4}$ resulted in higher recoveries of MDA and precise results among replicates. The same experiment was performed with 2, 4-TDA and HDA and back extraction into $0.5 \% \mathrm{H}_{2} \mathrm{SO}_{4}$ also produced higher recoveries.

\subsubsection{Extracted calibration curve.}

Different concentrations of MDA, 2, 4-TDA and HDA were spiked into $0.5 \mathrm{mg} / \mathrm{mL}$ HSA and $\mathrm{Hb}$ and hydrolyzed for $16 \mathrm{hr}$ at $100{ }^{\circ} \mathrm{C}$. The diamines were extracted as previously described in section 2.3.6, derivatized and analyzed by HPLC. Human serum albumin and hemoglobin were used to evaluate effect of proteins on extraction efficiency. Figures 3.7 show a calibration curve obtained when MDA was spiked in $0.5 \mathrm{mg} / \mathrm{ml} \mathrm{Hb}$. The same results were obtained when the diamine were spiked into 
HSA (data not shown). Similar calibration curves were also obtained with 2,4-TDA and HDA.

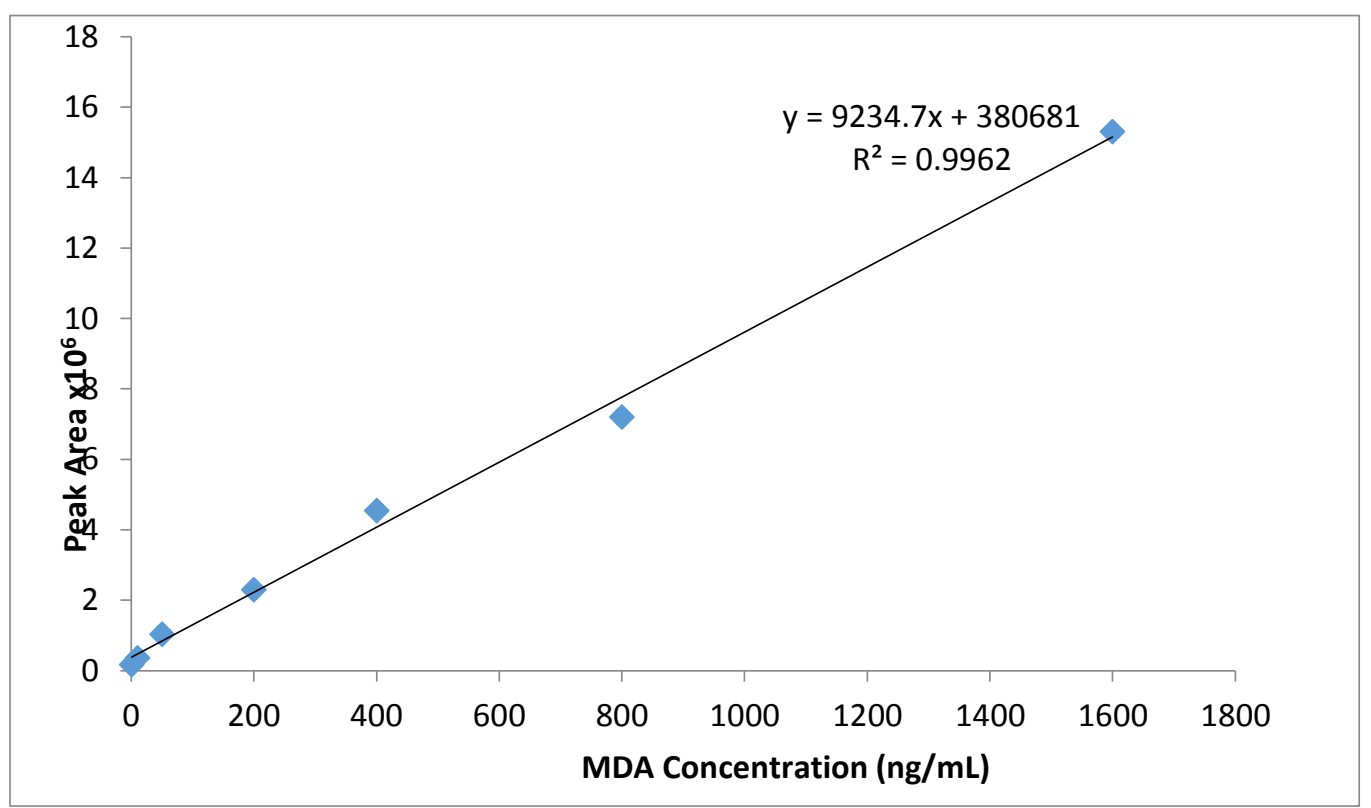

Figure 3.7: Calibration curve obtained when MDA was spiked in $0.5 \mathrm{mg} / \mathrm{ml} \mathrm{Hb}$, extracted and derivatized with fluorescamine

\subsection{DISCUSSION AND CONCLUSION}

There are several methods that have been used to characterize dNCO-protein conjugates in association with dNCO-specific antibody detection immunoassays and also for biomonitoring assays of dNCO exposure ${ }^{58,80}$. Measurement of total conjugated and free dNCO hydrolysis products from urine and plasma, such as MDA, analyzed following derivatization by gas chromatography (GC-MS) has been extensively employed as a bio monitoring tool for dNCO exposure ${ }^{81}$. These methods are based on determination of MDA after strong acid or base hydrolysis of MDIprotein adducts similar to that employed in the current study. Although measurement 
of the diamine hydrolysis product has been used for biomonitoring, only one study has reportedly applied this approach to characterize in vitro prepared HSA conjugates ${ }^{82}$.

Several solvents used for the extraction of diamines derived from dNCO hydrolysis are commercially available. These include toluene, dichloromethane, and ethyl acetate 74,83. Toluene is the most commonly extraction solvent reported for both TDI derived TDA and MDI derived MDA; however, MDA has poor solubility in toluene. Based on extraction efficiencies, ethyl acetate was chosen as the extraction solvent for extraction of MDA and dichloromethane for extraction of both 2, 4-TDA and HDA. Loss of MDA was observed on complete solvent evaporation under nitrogen but partial evaporation of ethyl acetate with subsequent back extraction into $0.5 \% \mathrm{H}_{2} \mathrm{SO}_{4}$ produced high, consistent recoveries and was used to extract the diamine from ethyl acetate into an aqueous solvent prior to derivatization.

This HPLC method based on fluorescence detection is applicable for absolute quantification of diisocyanate conjugation to proteins by quantifying the diisocyanate hydrolysis product following conjugate hydrolysis. This method is inexpensive, simple, and sensitive (limit of detection [LOD] $=1 \mathrm{ng} / \mathrm{ml}$ ). Mass spectral methods incorporate an isotopic internal standard that may increase accuracy, especially where matrix effects may alter extraction efficiency. However, the external standard methodology used for quantification of laboratory haptenated proteins where there is a uniform matrix provides sufficient accuracy for quantification of mass of dNCOprotein conjugated. 


\section{CHAPTER 4}

\section{CHARACTERIZATION OF METHYLENE DIPHENYL DIISOCYANATE CONJUGATED HUMAN SERUM ALBUMIN AND HEMOGLOBIN}

\subsection{INTRODUCTION}

Diagnosis of dNCO-induced OA remains confounded by methodological limitations

${ }^{84}$. Immunoassay standardization is critical for optimization of immunoassays used to detect diisocyanate specific antibodies in workers' sera as well as comparison of results across studies ${ }^{85}$. A number of factors that may affect results from these immunoassays include the $\mathrm{dNCO}$ used, the carrier protein employed, dNCO-protein reaction conditions, and post-reaction processing of the haptenated protein. The variability of results obtained in these immunoassays may also be due in part to a lack of standardization in conjugate preparation and characterization.

HSA is the most common carrier protein used for dNCO antibody immunoassays ${ }^{80}$ due to its prevalence in plasma to form MDI adducts ${ }^{86}$. Other molecules, such as keratin 18 , tubulin ${ }^{87}$, and the peptide, glutathione ${ }^{88}$ have been reported to be modified by dNCO exposure. Hemoglobin-MDI haptenation occurs in vivo following MDI exposure. Sabbioni and coworkers ${ }^{70}$ reported MDI binding to the $\mathrm{N}$-terminal valine of $\mathrm{Hb}$ in $\mathrm{MDI}$ exposed rats and proposed $\mathrm{Hb}-\mathrm{MDI}$ as a biological marker of MDI exposure. The same authors also found the $\mathrm{N}$-terminal adduct with valine in globin of a TDI-exposed worker and in two women with polyurethane-covered breast implants ${ }^{89}$. The immunogenicity of adducted proteins that have been identified other than albumin has not been tested; however, the fact that haptenated keratin and tubulin 
were identified immunochemically suggests that multiple haptenated protein species formed following exposure may be antigens. Due to the lack of characterization of protein- $\mathrm{dNCO}$ adducts, antibody reactivity toward other endogenous haptenated proteins may be overlooked using conventional detection approaches. Other proteins assessed as carrier proteins for dNCOs, however, have not been as effective at detecting dNCO-specific antibody in the blood of exposed workers. It is not known whether this is due to varying degrees of dNCO adduction to different proteins or antibody recognition. Characterization of different $\mathrm{dNCO}-$ protein conjugates, therefore, is important to further our understanding of dNCO haptenation and adduction.

Although MDI accounts for almost $60 \%$ of the global market of dNCO worldwide, most of the published biomedical dNCO research studies have used toluene diisocyanate (TDI), possibly because of MDI's lower vapor pressure and lower reactivity. Its lower volatility makes respiratory exposure less likely and harder to generate into the air for animal studies. There was also a switch about 15 years ago from TDI use to MDI use with respect to industrial applications. This could also explain why there are not as many research studies reported on MDI.

Our previous research has been directed towards delineating the concentrationdependent increase in specific dNCOs such as toluene diisocyanate (TDI) binding sites on $\mathrm{HSA}^{90}$. In these studies, the predominant TDI binding sites on HSA were lysine residues, although binding to the $\mathrm{N}$-terminal arginine and to glutamine were also observed. In another study performed in our laboratory ${ }^{91}$, MDI was shown to be 
bound to the same sites as TDI, but overall the reactivity was reduced. In this study, MDI-HSA conjugates were characterized with the aim of developing a standardized approach for screening for IgE- and IgG-specific antibodies. MDI reactivity toward $\mathrm{Hb}$ was also examined and compared with HSA because dNCO-adducted hemoglobin has been measured from the blood of exposed workers and used as a biological marker of dNCO exposure ${ }^{92}$.

Wong and coworkers ${ }^{93}$ reported that acrylonitrile- adducted $\mathrm{Hb}$ was antigenic. In another study, Pien and coworkers ${ }^{94}$ found that rats exposed to the respiratory allergen and inducer of late respiratory systemic syndrome, trimellitic anhydride (TMA), by inhalation produced IgG that recognized both TMA-haptenated albumin and $\mathrm{Hb}$. They demonstrated, through cross-inhibition studies, that TMA-albumin and TMA-Hb share antigenic determinants. Collectively, these studies suggest that haptenated hemoglobin can be antigenic.

These experiments sought to (a) use the HPLC method developed to quantify amount of MDI conjugation to both $\mathrm{HSA}$ and $\mathrm{Hb}$, (b) evaluate other established techniques used to characterize MDI conjugates that are formed with different proteins and (c) suggest a set of methods and techniques that can be used to characterize conjugates that are used for detection of MDI specific antibodies in workers' sera. 


\subsection{RESULTS AND DISCUSSION}

\subsubsection{Mapping the binding sites of MDI on $\mathrm{Hb}$}

$\mathrm{Hb}$ was reacted in vitro (PBS, $\mathrm{pH} 7.4$ ) to MDI at MDI/Hb molar ratios of 1:1 to 40:1.

The conjugates produced were digested with trypsin, and resultant peptides were analyzed by UPLC-MS/MS to determine MDI binding sites. Examination of the tandem mass spectra of the tryptic peptides allowed assignment of conjugation sites on $\mathrm{Hb}$ as described by Hettick et $a l^{95}$. Fig. 4.1 is a tandem mass spectrum of the b-subunit of $\mathrm{Hb}$ tryptic fragment 1 to 17 conjugated to MDI on the $\mathrm{N}$-terminal valine. The conjugated peptide has a mass of 2098.07, which is in agreement with the theoretical mass of the fragment. The $\mathrm{b}_{2}$ and $\mathrm{b} *_{7}$ ions were conjugated to MDI, appearing $200 \mathrm{u}$ higher in mass than the theoretical $b_{2}$ and $b_{7}$ ions, indicating that MDI is covalently bound to the $\mathrm{N}$-terminal valine at position 1 . On the other hand, $\mathrm{y}_{\mathrm{n}}$-type ions, $\mathrm{y}_{2}$ to $\mathrm{y}_{14}$, all appear at the correct theoretical masses, again further confirming that MDI is bound to the N-terminal valine. Polymerization was observed on Lys66 at a 10:1 $\mathrm{MDI} / \mathrm{Hb}$ molar conjugation ratio and above. 


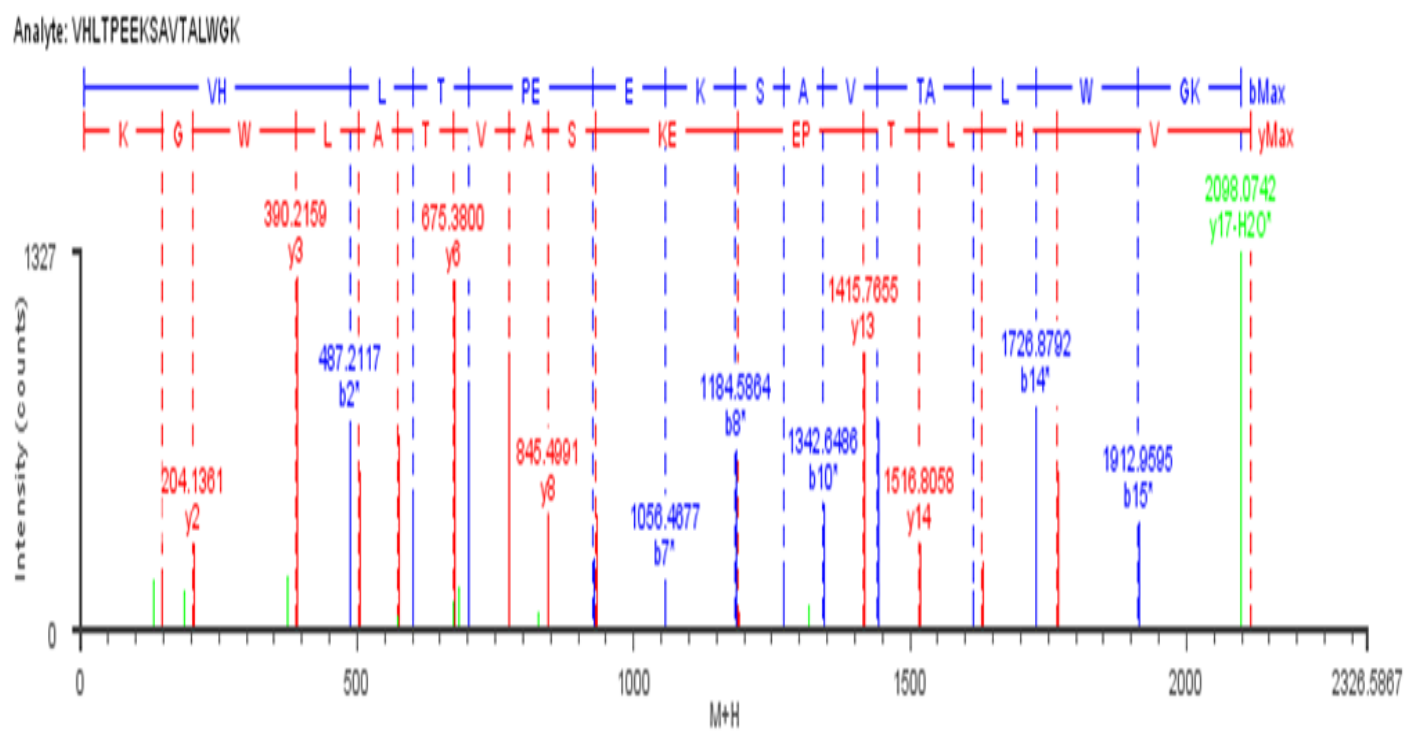

Figure 4.1: Tandem mass spectrum of hemoglobin subunit $\beta$ fragment 1-17 conjugated to MDI on the N-terminal valine residue.

Table 4.1 shows the concentration-dependent specific binding sites identified for MDI on $\mathrm{Hb}$ when MDI was added at molar ratios from 1:1 to 40:1 MDI/Hb. Eight binding sites were identified at the highest concentration of MDI used, including the $\mathrm{N}$ terminal amine of valine on both the alpha and beta chains. MDI bound to two lysines on the alpha chain and four additional lysines on the beta chain. The two N-terminal valines of the alpha and beta chains, as well as Lys66 on the beta chain, were observed to bind at the lowest conjugation ratio of 1:1 MDI/Hb. Increasing MDI concentrations increased the number of sites bound to a maximum of eight. All eight binding sites were conjugated at a 10:1 molar ratio. Increasing the concentration to 40:1 did not increase the number of different amino acids bound. 
Table 4.1: MDI Hemoglobin conjugation sites

\begin{tabular}{|c|c|c|c|c|}
\hline & \multicolumn{4}{|c|}{ MDI:Hb Conjugation Ratios } \\
\hline Binding Site & 1:1 & $5: 1$ & 10:1 & 40:1 \\
\hline \multicolumn{5}{|l|}{ Alpha subunit } \\
\hline Val 1 & $\mathrm{x}$ & $\mathrm{x}$ & $\mathrm{x}$ & $\mathrm{x}$ \\
\hline Lys 7 & & $\mathrm{x}$ & $\mathrm{x}$ & $\mathrm{x}$ \\
\hline Lys 40 & & $\mathrm{x}$ & $\mathrm{x}$ & $\mathrm{x}$ \\
\hline \multicolumn{5}{|l|}{ Beta subunit } \\
\hline Val 1 & $\mathrm{x}$ & $\mathrm{x}$ & $\mathrm{x}$ & $\mathrm{x}$ \\
\hline Lys 8 & & & $\mathrm{x}$ & $\mathrm{x}$ \\
\hline Lys 61 & & & $\mathrm{x}$ & $\mathrm{x}$ \\
\hline Lys 65 & & & $\mathrm{x}$ & $\mathrm{x}$ \\
\hline Lys 66 & $\mathrm{x}$ & $\mathrm{x}$ & $\mathrm{x}$ & $\mathrm{x}$ \\
\hline
\end{tabular}

In contrast, MDI conjugates five different HSA lysines at 1:1 MDI/HSA ${ }^{91}$.

Conjugation to the N-terminal Asp in HSA was not observed until the MDI

concentration was raised to 5:1 MDI/HSA and two glutamine sites were bound at the higher conjugation ratios ${ }^{91}$. In addition, the number of different amino acid binding sites increased through the entire MDI concentration range, with 20 different binding sites conjugated at 40:1 MDI/HSA. Table 4.2 compares the number of observed binding sites for $\mathrm{Hb}$ and HSA. HSA has more lysine binding sites accessible for MDI binding compared with $\mathrm{Hb}$ through the entire MDI concentration range. However, relative to the number of potential lysine binding sites in the two proteins, both proteins showed relatively equivalent percentage binding, where the percentage binding was calculated as the number of observed binding sites divided by the total number of potential binding sites (lysines $+\mathrm{N}$-terminal amines), expressed as a percentage. 
Table 4.2: Comparison of MDI binding sites in $\mathrm{Hb}$ and HSA

\begin{tabular}{|l|l|l|l|l|}
\hline & $\begin{array}{l}\text { Binding sites } \\
\text { on } \mathrm{Hb}\end{array}$ & $\begin{array}{l}\text { Binding sites on } \\
\text { HSA }^{91}\end{array}$ & \% Binding Hb & $\begin{array}{l}\text { \% Binding } \\
\text { HSA }\end{array}$ \\
\hline $\begin{array}{l}1: 1 \mathrm{MDI}: \\
\text { Protein }\end{array}$ & 3 & 5 & 13 & 9 \\
\hline $\begin{array}{l}5: 1 \mathrm{MDI}: \\
\text { Protein }\end{array}$ & 5 & 11 & 21 & 19 \\
\hline $\begin{array}{l}10: 1 \mathrm{MDI}: \\
\text { Protein }\end{array}$ & 8 & 13 & 33 & 22 \\
\hline $\begin{array}{l}\text { 40:1 MDI: } \\
\text { Protein }\end{array}$ & 8 & 20 & 33 & 34 \\
\hline $\begin{array}{l}\text { Total number } \\
\text { of potential } \\
\text { binding sites }\end{array}$ & 24 & 59 & & \\
\hline
\end{tabular}

\subsubsection{Quantification of MDI binding in $\mathrm{Hb}$ and $\mathrm{HSA}$}

MDI-conjugated HSA and $\mathrm{Hb}$ were hydrolyzed under strong acid conditions to obtain free MDA. The MDA was extracted and derivatized with fluorescamine and analyzed using HPLC with fluorescence detection. Quantification of the number of moles of MDI bound to $\mathrm{Hb}$ and HSA measured following acid hydrolysis is reported in Table 4.3. The number of moles of MDI conjugated to both proteins increased with increasing concentration of MDI used for conjugation. On a per mole basis, HSA bound a greater amount of MDI than $\mathrm{Hb}$ and the effect is more pronounced at very low concentrations of MDI as almost 18 times more MDI was conjugated to HSA than $\mathrm{Hb}$ at 1:1 MDI: protein compared to only 2 times more MDI conjugated to HSA than $\mathrm{Hb}$ at 40:1 MDI: protein. In addition, although the number of different amino acid sites did not increase between 10:1 and 40:1 MDI/Hb, the absolute amount of MDI 
bound increased 3-fold. This may be indicative of an increasing number of specific lysines bound as well as increased MDI polymerization onto a single protein site.

Table 4.3: The molar quantities of MDI bound to HSA and $\mathrm{Hb}$ per mole of protein obtained

\begin{tabular}{|l|l|l|l|}
\hline Sample & *Moles MDI & * Moles MDI per & Moles MDA \\
& per mole Hb & mole HSA & $\begin{array}{l}\text { (HSA)/Moles } \\
\text { MDA(Hb) }\end{array}$ \\
\hline 1:1 MDI: Protein & $0.03 \pm 0.01$ & $0.59 \pm 0.11$ & 17.96 \\
\hline 5:1 MDI: Protein & $0.85 \pm 0.04$ & $2.73 \pm 0.29$ & 3.20 \\
\hline 10:1 MDI: Protein & $1.24 \pm 0.03$ & $3.93 \pm 0.33$ & 3.17 \\
\hline 40:1 MDI: Protein & $3.87 \pm 0.12$ & $8.15 \pm 0.95$ & 2.10 \\
\hline
\end{tabular}

\subsubsection{Cross-linking in MDI-HSA- TNBS assay}

The 2, 4, 6-Trinitrobenzenesulfonic acid (TNBS) assay has been widely used as a reagent for determining the concentrations of primary amines and degree of substitution. Since dNCOs are bi-functional, when one of the isocyanate moiety binds to the protein, the other can hydrolyze into a primary amine and be available to react with TNBS. In this case, there will be no net loss of protein amine reactivity. Only when both isocyanate moieties react with amine groups on proteins would there be a 
net loss of amine groups in the protein. Thus, loss of amine reactivity toward TNBS is indicative of the extent of cross linking not of the absolute degree of substitution. This assay will however not distinguish between intra- and intermolecular cross-linking by dNCO or polymerized MDI.

The TNBS assay was therefore used in this study to evaluate the extent of cross linking that occurs when MDI conjugates to HSA. Table 4.4 shows a concentrationdependent loss of available primary amines with increasing MDI concentrations and, thus an increase in the amount of dNCO cross-linking of protein residues. Approximately $60 \%$ of primary amines in HSA are cross-linked at the highest MDI concentration. MDI-Hb cross-linking could not be evaluated by TNBS due to spectral interference. Use of fluorescamine to assess free amines on MDI-Hb was not successful either due to fluorescent quenching by $\mathrm{Hb}$ at $510 \mathrm{~nm}$ (data not shown).

Table 4.4: Cross-linking in HSA-MDI evaluated using the TNBS assay

\begin{tabular}{|l|l|l|}
\hline Sample & $\begin{array}{l}\text { TNBS Abs(as a \% of HSA } \\
\text { control) }\end{array}$ & $\begin{array}{l}\text { * \% cross linking } \\
\text { in MDI: HSA }\end{array}$ \\
\hline No MDI & 100.00 & $0.00 \pm 0.00$ \\
\hline 1:1 MDI: Protein & 83.42 & $16.58 \pm 5.21$ \\
\hline 5:1 MDI: Protein & 75.04 & $24.96 \pm 2.14$ \\
\hline 10:1 MDI: Protein & 60.29 & $39.71 \pm 4.51$ \\
\hline 40:1 MDI: Protein & 42.12 & $57.88 \pm 7.07$ \\
\hline
\end{tabular}


Figure 4.2 is a plot of the dose-dependent total MDI bound per mole of HSA and the approximate number of MDI that are cross-linked obtained by multiplying the percent cross-linking from the TNBS assay times the average of 10 TNBS bound per mole HSA divided by 2 ( 1 cross-linked MDI binds 2 amines). Thus, loss of $57.88 \%$ of primary amines at 40:1 MDI: HSA X 10 moles TNBS/HSA $=5.8$ amines blocked. One MDI blocks 2 amines equaling 2.9 MDI cross-linked per mole HSA. The estimate of the number of MDI involved in cross-linking assumes an insignificant number of protein residues cross-liked by MDI polymer.

Number of MDI cross-linked $=\%$ cross linking X 10 (TNBS bound/mole HSA)

2 (Number of amines cross-linked by $1 \mathrm{MDI}$ )

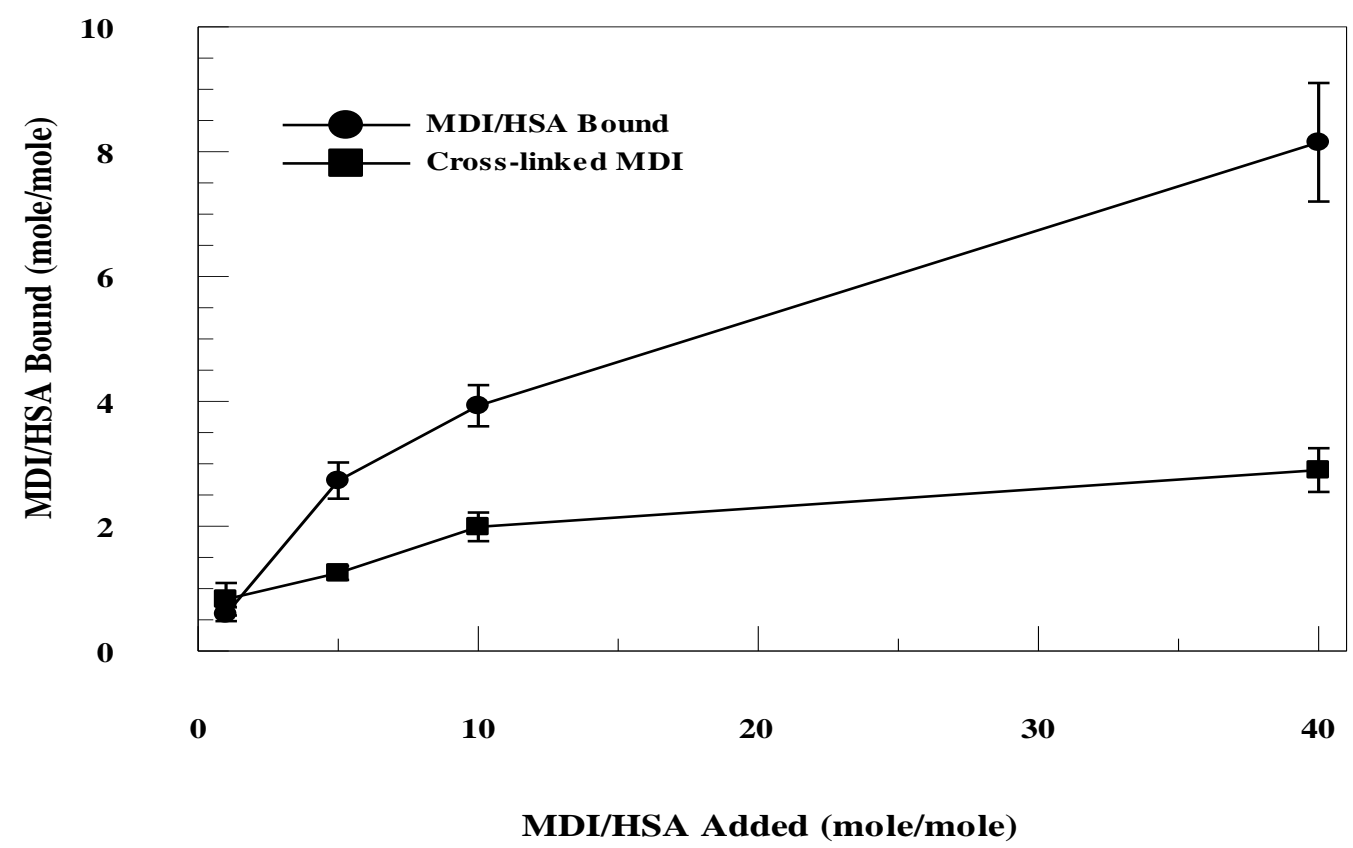

Figure 4.2: Dose-dependent total MDI bound per mole of HSA and the approximate number of MDI that are cross-linked. 


\subsubsection{Gel electrophoresis: qualitative assessment of crosslinking in MDI-HSA and MDI-Hb}

Sodium dodecyl sulfate polyacrylamide gel electrophoresis (SDS-PAGE) was

employed to qualitatively examine the extent of binding and cross-linking. Under

denaturing conditions, intra-molecular cross-linked proteins migrated at a slower rate

compared with native protein and also prevented complete protein denaturation, causing an apparent migration like that of a smaller protein. Figure 4.3 shows an $8 \%$

SDS-PAGE gel of $0.5 \mathrm{mg} / \mathrm{ml} \mathrm{HSA}$ reacted to MDI at different molar ratios of MDI/HSA. MDI conjugation of HSA at a 1:1 MDI/HSA conjugation ratio (lane 3) resulted in 68- and 71-kDa equivalent bands. At 5:1 MDI/HSA (lane 4), the 68-kDa HSA band and the 71-kDa band are still observable with reduced resolution. At the higher (10:1 and 40:1) MDI/HSA conjugation ratios (lanes 5 and 6, respectively), broad bands that migrated like smaller molecules with leading edges of the bands at apparent masses of 63 and $53 \mathrm{kDa}$ were observed. In addition, a faint band between 100 and $150 \mathrm{kDa}$ was also observed in lane 6, presumably due to intermolecular MDIHSA cross-linking. 


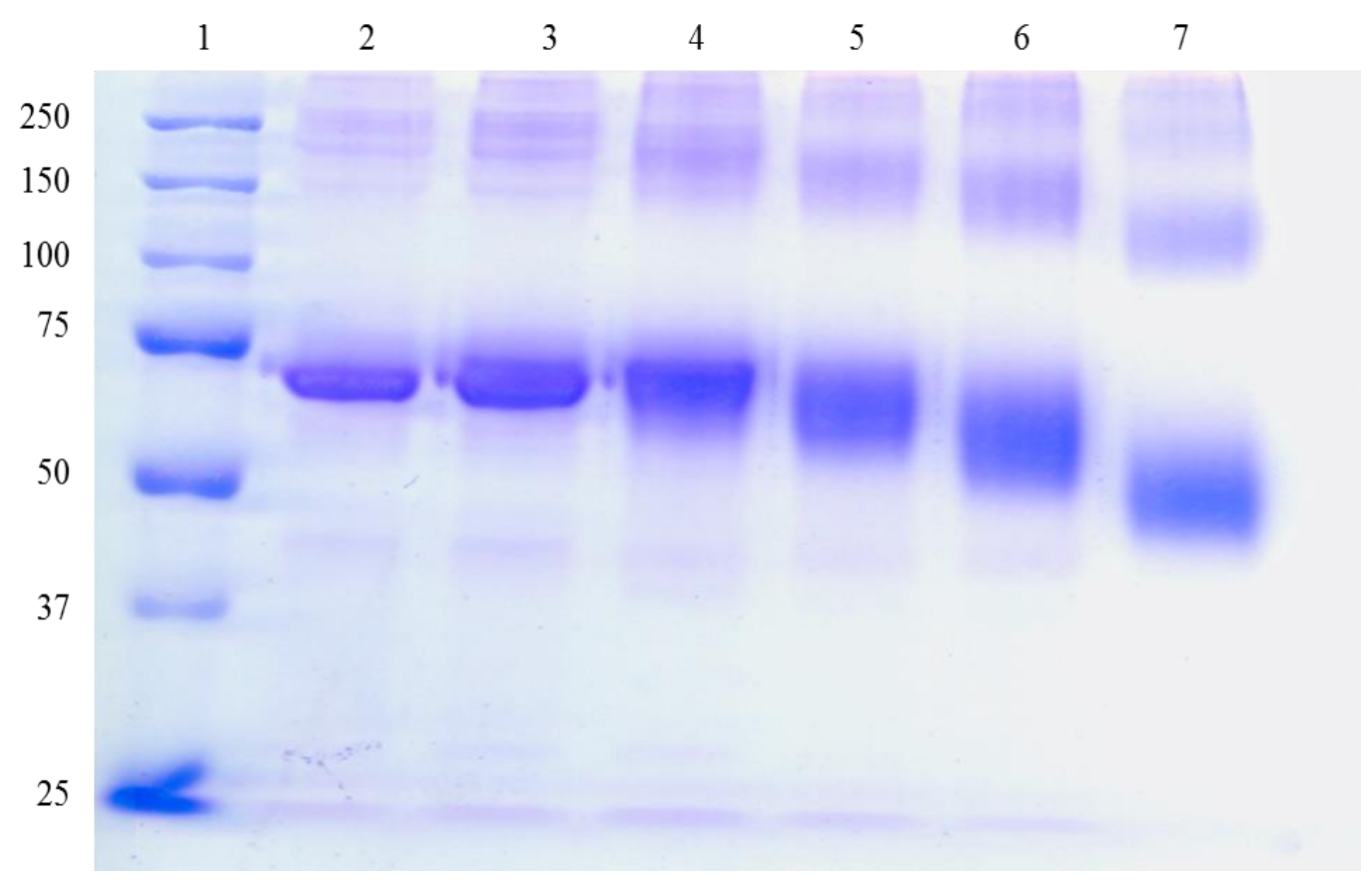

Figure 4.3: An 8\% denaturing gel of MDI: HSA. Lane lis the molecular weight marker, lane 2 is HSA, lanes 3, 4, 5, and 6 are 1:1, 5:1, 10:1, and 40:1 MDI: HSA conjugates respectively.

Native gel electrophoresis of MDI-HSA conjugates was also assessed (Figure 4.4); however, higher molecular weight bands 2- to 3-fold the mass of HSA were observed in control samples (lane 2) and identified by digestion and UPLC-MS/MS to be HSA. These results demonstrated the aggregation of HSA under the assay conditions and prevented the observation of potential intramolecular cross-linking. An MDI concentration dependent increase in migration of the conjugate band was also observed in the MDI-HSA conjugates similar to that observed under denaturing conditions, suggestive of intramolecular cross- linking. The faster migration (apparent smaller size) may be possibly attributable to exclusion of intramolecular water(s), effectively decreasing the size. 


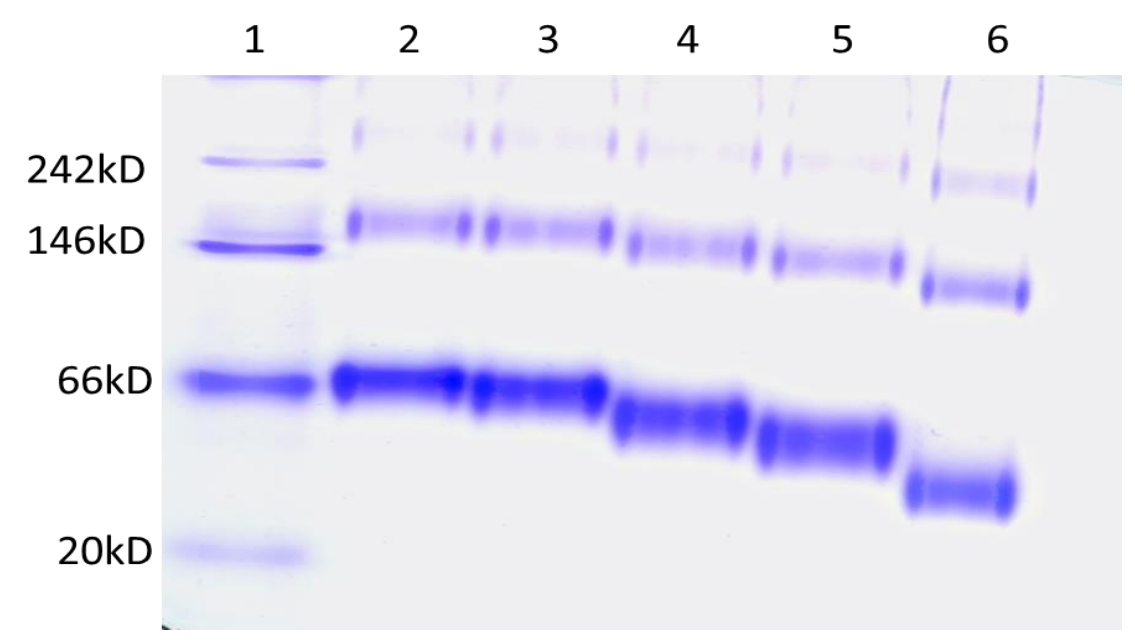

Figure 4.4: An 8\% native gel of MDI: HSA. Lane 1 is the molecular weight marker, lane 2 is HSA and lanes 3, 4, 5, and 6 are 1:1, 5:1, 10:1, and 40:1 MDI: HSA respectively.

Figure 4.5 is a $4 \%$ to $20 \%$ gradient gel of $0.5 \mathrm{mg} / \mathrm{ml} \mathrm{Hb}$ reacted to MDI at four different mole ratios of $\mathrm{MDI} / \mathrm{Hb}$. Denaturation of $\mathrm{Hb}$ resulted in the dissociation of the alpha and beta subunits that migrated at 15.2 and $15.9 \mathrm{kDa}$, respectively. Upon MDI conjugation, there was emergence of a band at approximately $30 \mathrm{kDa}$, which is a result of two crosslinked subunits. A dark unresolved smear of high-molecular-weight compounds also emerged at $45 \mathrm{kDa}$ and above, suggestive of extensive multiple intersubunit cross-linking, and the intensity of this band increased with increasing MDI concentrations. A downward shift of the 15.2- and 15.9-kDa subunits with increased MDI concentrations was also observed, similar to that found with the MDI-HSA conjugates. 


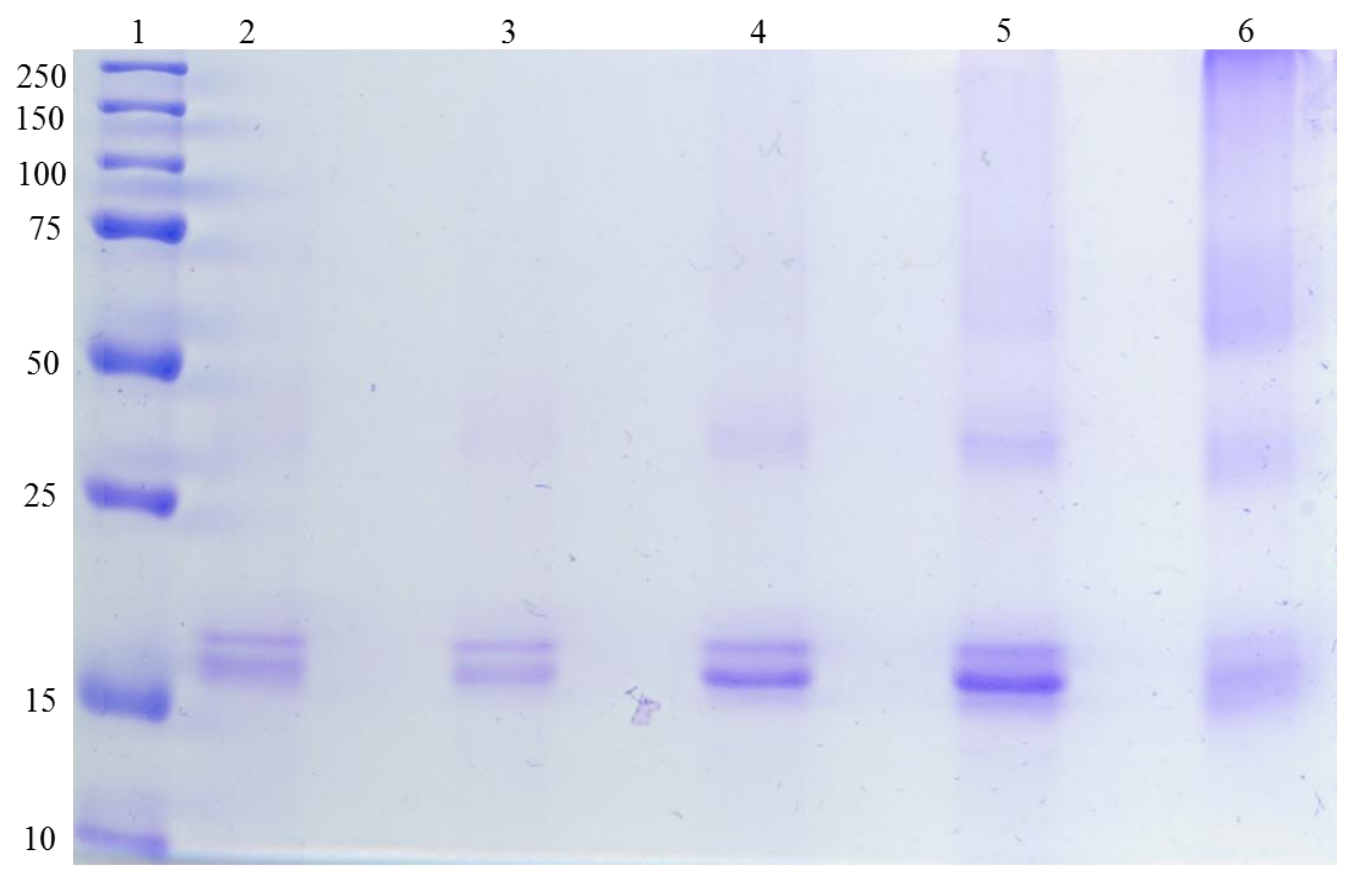

Figure 4.5: denaturing 4\% to 20\% gradient gel of MDI-Hb. Lane 1 is the molecular weight marker, lane 2 is $H b$, and lanes 3, 4, 5, and 6 are 1:1, 5:1, 10:1, and 40:1 MDI: $H \mathrm{Hb}$ respectively.

\subsubsection{ELISA assessment of percentage of albumin molecules conjugated}

An immunoassay was developed using a mAb IgM developed that detects MDI$\mathrm{HSA}^{96}$. The MDI mAb was used as the capture antibody in solid phase, and MDIHSA conjugates were detected using an alkaline phosphatase-conjugated anti-human albumin antibody. In this assay, the amount of HSA with at least one nucleophilic site conjugated by MDI (vs. number of MDI bound per albumin molecule) was quantified. As shown in Figure 4.6, the ELISA absorbance becomes saturated at a binding ratio of 
20:1, with no further increase at 40:1. These results demonstrate that all HSA molecules are conjugated to at least one MDI at the 20:1 MDI/HSA conjugation ratio.

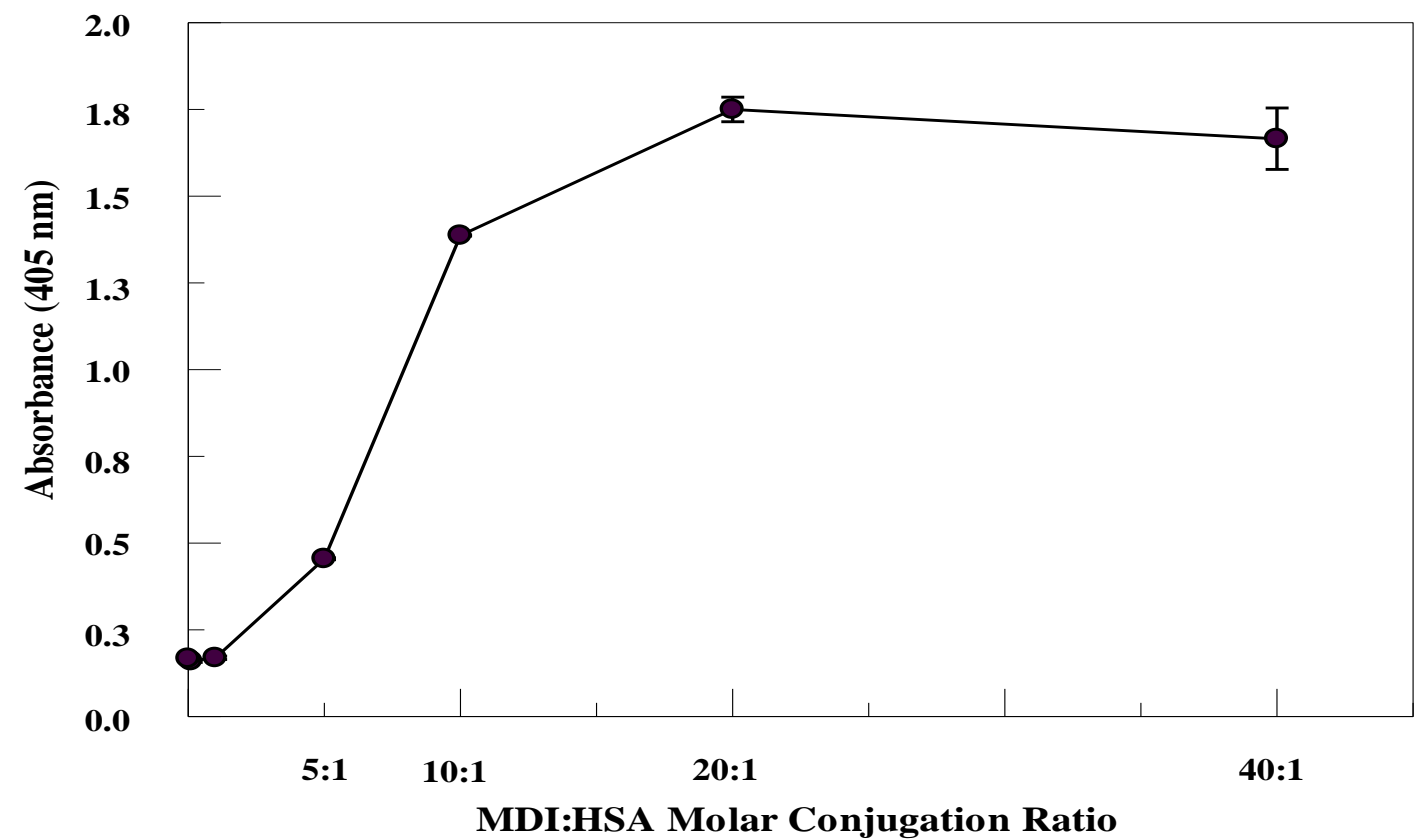

Figure 4.6: Immunoassay of MDI haptenated HSA.

\subsection{CONCLUSION}

In the current study, MS/MS was used to delineate specific MDI binding sites on $\mathrm{Hb}$ and 8 binding sites were identified in $\mathrm{Hb}$. Except for the $\mathrm{N}$-terminal valines on both the alpha and beta subunits, Lys66 was the only non-terminal binding site that was observed at the lowest MDI concentration studied (1:1 MDI/Hb). Although additional MDI binding sites were not observed when the binding ratio was increased from 10:1 to 40:1, the number of moles of MDI bound per mole $\mathrm{Hb}$ increased 3-fold.

Using the TNBS assay, a concentration-dependent increase in the amount of MDI cross-linking of HSA was observed with loss of $58 \%$ of primary amine reactivity at 
40:1 MDI/HSA translating to 2.9 moles MDI cross-linked per mole HSA. The estimate of the number of MDI cross-linking assumes that an insignificant number of protein residues are cross-linked by MDI polymer. Due to spectral interference from $\mathrm{Hb}$, crosslinking in MDI-Hb conjugates could not be assessed quantitatively. Intermolecular cross-linking was also observed in both MDI haptenated HSA and $\mathrm{Hb}$ at the higher conjugation ratios using polyacrylamide gel electrophoresis by the appearance of bands approximately 2-fold the monomeric protein masses.

Immunoassays using a recently developed mAb (15D4) specific for MDI-conjugated protein can be formatted in a variety of configurations to provide further information to develop a standardized antigen for diisocyanate-specific antibody screening. The ELISA format employed in the current study uses an anti-MDI-protein IgM as the capture antibody and a labeled anti-HSA as the detection antibody and, thus, measures the number of albumin with at least one MDI molecule covalently bound. No increase in immuno-reactivity was observed at reaction ratios above 20:1 MDI/HSA, suggesting that any increase in bound MDI was due to polymerization and reaction to additional HSA nucleophilic sites versus reaction to unbound HSA. Direct binding of the haptenated HSA to an ELISA plate with measurement of binding by an mAb (data not shown) is also an approach that can be used to standardize the antigenicity of the haptenated protein. Wisnewski and coworkers ${ }^{97}$ reported that maximal MDI-specific IgG reactivity of exposed workers' sera against MDI-HSA in their immunoassay was observed at a conjugation ratio of $200 \mu \mathrm{g} \mathrm{MDI} / \mathrm{mg} \mathrm{HSA}(\sim 50: 1)$. It must be noted that the HSA concentration reacted to MDI was 10 times greater than that used in the 
current study, which very possibly altered the final product given the potential for greater intermolecular crosslinking and polymerization associated with these higher protein and MDI concentrations.

Multiple methods should be used to fully characterize dNCO-HSA conjugates for use in standardized immunoassays for screening dNCO-specific IgE and IgG from workers' sera. These analyses should include (i) measurement of the amount of diamine/mole protein following acid hydrolysis, (ii) TNBS measurement of crosslinking, (iii) denature gel electrophoresis for indication of inter- and intramolecular crosslinking, and (iv) use of mAb for antigenicity standardization. Both qualitative and quantitative differences in MDI binding were observed between $\mathrm{Hb}$ and $\mathrm{HSA}$ conjugates, suggesting that normalization to conjugation ratio is not sufficient to compare antigenicity of different diisocyanate-haptenated proteins. 


\section{CHAPTER 5}

\section{COMPARATIVE ANALYSIS OF TOLUENE DIISOCYANATE AND HEXAMETHYLENE DIISOCYANATE CONJUGATION TO HUMAN SERUM ALBUMIN AND HEMOGLOBIN}

\subsection{INTRODUCTION}

Toluene diisocyanate (TDI) and hexamethylene diisocyanate (HDI) are widely used in the manufacture of polyurethane products and both have been reported to cause respiratory sensitization and occupational asthma $(\mathrm{OA})$ in exposed workers ${ }^{98}$. Once allergic sensitization to isocyanates occurs, asthmatic reactions may be triggered by exceedingly minute concentrations ${ }^{99,100}$. Both TDI and HDI are relatively volatile and exposure occurs predominantly through inhalation at workplaces ${ }^{17}$. However, dermal exposure has also been reported to cause asthma-like symptoms.

There are differences in reactivity between aromatic isocyanates and aliphatic isocyanates. In a study by Wisnewski et $a l^{101}$ in which albumin was conjugated to TDI and HDI by GSH-TDI and GSH-HDI, respectively, the kinetics of GSH-HDI mediated albumin carbomylation at neutral $\mathrm{pH}$ was substantially slower compared with those of GSH-TDI. These researchers also found that GSH-HDI conjugates were more stable compared to aromatic isocyanate-GSH conjugates which probably explain the slower rate of HDI carbomylation by GSH-HDI. The hydrolysis of aliphatic isocyanates is also much slower than aromatic isocyanates. The reactivity of HDI directly conjugated to proteins may however confer different kinetics. 
Diisocyanate-adducted hemoglobin in vivo immunogenicity or antigenicity has not yet been evaluated. Wong and coworkers ${ }^{93}$ reported that acrylonitrile- adducted $\mathrm{Hb}$ was antigenic. Pien and coworkers ${ }^{102}$ also found that rats exposed to the respiratory allergen and inducer of late respiratory systemic syndrome, trimellitic anhydride (TMA), by inhalation produced IgG that recognized both TMA-haptenated albumin and $\mathrm{Hb}$. They demonstrated, through cross inhibition studies, that TMA-albumin and TMA-Hb share antigenic determinants. Collectively, these studies suggest that haptenated hemoglobin can be antigenic.

Previous work was focused on developing an HPLC method for quantitative characterization of dNCO-protein adducts as well as characterization of MDI-HSA and MDI-Hb conjugates for immunoassay standardization ${ }^{59}$. The experiments reported herein sought to (i) extend the characterization of the conjugates formed upon reaction of TDI and HDI with HSA and Hb to determine the amount of diisocyanate bound, (ii) utilize the TNBS assay and SDS gel electrophoresis to evaluate extent of intra- and inter-molecular cross linking, (iii) delineate TDI binding sites on $\mathrm{Hb}$ and (iv) evaluate the antigenicity of TDI and HDI conjugates using a mAb produced in our lab.

\subsection{RESULTS AND DISCUSSION}

\subsubsection{Mapping TDI binding sites on $\mathrm{Hb}$}

$\mathrm{Hb}$-TDI conjugates were digested with trypsin, and resultant peptides were analyzed by UPLC-MS/MS to determine TDI binding sites. Examination of the tandem mass 
spectra of the tryptic peptides allowed assignment of conjugation sites on $\mathrm{Hb}$ as described previously ${ }^{59}$. Table 5:1 below shows the concentration-dependent specific binding sites identified for TDI on $\mathrm{Hb}$.

Table 5.1 TDI binding sites on $\mathrm{Hb}$ at different concentrations of TDI.

\begin{tabular}{|l|l|l|l|l|}
\hline & $1: 1$ & $5: 1$ & $10: 1$ & $40: 1$ \\
\hline Alpha subunit & & & & \\
\hline Val 1 & $\mathrm{x}$ & $\mathrm{x}$ & $\mathrm{x}$ & $\mathrm{x}$ \\
\hline Lys 11 & & $\mathrm{x}$ & $\mathrm{x}$ & $\mathrm{x}$ \\
\hline Lys 16 & & & $\mathrm{x}$ & $\mathrm{x}$ \\
\hline Lys 40 & & & & $\mathrm{x}$ \\
\hline Beta subunit & & & & $\mathrm{x}$ \\
\hline Val 1 & $\mathrm{x}$ & $\mathrm{x}$ & $\mathrm{x}$ & $\mathrm{x}$ \\
\hline Lys 17 & & & $\mathrm{x}$ & $\mathrm{x}$ \\
\hline Lys 144 & & & $\mathrm{x}$ & $\mathrm{x}$ \\
\hline Lys 61 & & & & \\
\hline
\end{tabular}

Eight binding sites were identified at the highest concentration of TDI used, including the N-terminal valine on both the alpha and beta chains. TDI bound to three lysines on the alpha chain and three additional lysines on the beta chain. Only the two N-terminal valines of the alpha and beta chains were bound at the lowest conjugation ratio of 1:1 TDI:Hb. Increasing TDI concentrations increased the number of sites bound to a maximum of eight at 40:1 TDI:Hb. Although there are similarities with MDI binding sites previously reported (Table 4.1$)^{59}$, there are significant differences as well. MDI bound two lysines on the alpha chain compared to three for TDI and four lysines on the beta chain compared to three for TDI. Only lysine 40 of the alpha subunit and 
lysine 61 of the beta subunit were bound by both MDI and TDI. Lysines 11 and 16 of the alpha subunit and lysines 17 and 144 of the beta subunit were only observed in TDI (Table 5.1). On the other hand, lysine 7 of the alpha subunit and lysines 8, 65 and 66 of the beta subunit were only observed with MDI. Although MDI bound to the two N-terminal valines of both the alpha and beta subunits just as TDI, lysine 66 was bound by MDI at 1:1 MDI:Hb. This lysine was not bound by TDI even at the highest concentration of TDI used. All eight binding sites observed in MDI:Hb were conjugated at a 10:1 molar ratio and increasing the concentration to 40:1 did not increase the number of different amino acids bound. This is in contrast to TDI:Hb were the number of different amino acid binding sites increased throughout the entire TDI concentration range, with only six binding sites observed at 10: $1 \mathrm{TDI}$ : Hb. Table 5:2 below compares the binding sites observed for TDI and MDI on $\mathrm{Hb}$.

Table 5.2 Comparative analysis of MDI and TDI binding sites on $\mathrm{Hb}$.

\begin{tabular}{|l|l|l|l|l|}
\hline & \multicolumn{2}{|l|}{ Alpha subunit } & \multicolumn{2}{l|}{ Beta subunit } \\
\hline & MDI:Hb & TDI:Hb & MDI:Hb & TDI:Hb \\
\hline $\mathbf{1 : 1}$ & Val 1 & Val 1 & Val 1, Lys 66 & Val 1 \\
\hline $\mathbf{5 : 1}$ & $\begin{array}{l}\text { Val 1, Lys 7, } \\
\text { Lys 40 }\end{array}$ & Val 1, Lys 11 & Val 1, Lys 66 & Val 1 \\
\hline $\mathbf{1 0 : 1}$ & $\begin{array}{l}\text { Val 1, Lys 7, } \\
\text { Lys 40 }\end{array}$ & $\begin{array}{l}\text { Val 1, Lys 11, } \\
\text { Lys 16 }\end{array}$ & $\begin{array}{l}\text { Val 1, Lys 66, } \\
\text { Lys 8, Lys 61, } \\
\text { Lys 65 }\end{array}$ & $\begin{array}{l}\text { Val 1, Lys 17, } \\
\text { Lys 144 }\end{array}$ \\
\hline $\mathbf{4 0 : 1}$ & $\begin{array}{l}\text { Val 1, Lys 7, } \\
\text { Lys 40 }\end{array}$ & $\begin{array}{l}\text { Vys 1, Lys 11, Lys } \\
\text { Lyal 1, Lys 66, } \\
\text { Lys 8, Lys 61, } \\
\text { Lys 65 }\end{array}$ & $\begin{array}{l}\text { Val 1, Lys 17, } \\
\text { Lys 144, Lys } \\
\text { 61 }\end{array}$ \\
\hline
\end{tabular}


The differences in the binding sites between MDI and TDI can give an insight into the structural differences in the resultant conjugates, which potentially affects disease mechanisms.

\subsubsection{Quantification of TDI and HDI binding on Hb and HSA}

TDI and HDI-conjugated HSA and $\mathrm{Hb}$ were hydrolyzed as previously described in section 2.3.6 and the resultant TDA and HDA was extracted and derivatized with fluorescamine and quantified using HPLC. The number of moles of TDI and HDI bound to $\mathrm{Hb}$ and HSA is shown in Table 5:3 below.

Table 5.3: Amount in moles of TDI and HDI conjugated to HSA and Hb.

\begin{tabular}{|l|l|l|l|l|}
\hline $\begin{array}{l}\text { Ratio dNCO: } \\
\text { protein }\end{array}$ & \multicolumn{2}{|l|}{ dNCO: HSA } & \multicolumn{2}{l|}{ dNCO: Hb } \\
\hline & TDI: HSA & HDI: HSA & TDI: Hb & HDI: Hb \\
\hline $\mathbf{1 : 1}$ & $0.51 \pm 0.56$ & $0.04 \pm 0.41$ & $0.15 \pm 0.15$ & $0.02 \pm 0.21$ \\
\hline $\mathbf{5 : 1}$ & $2.65 \pm 0.23$ & $0.44 \pm 0.45$ & $0.57 \pm 0.02$ & $0.13 \pm 0.23$ \\
\hline $\mathbf{1 0 : 1}$ & $5.06 \pm 0.43$ & $0.82 \pm 0.36$ & $1.48 \pm 0.09$ & $0.32 \pm 0.60$ \\
\hline $\mathbf{4 0 : 1}$ & $12.86 \pm 0.56$ & $2.79 \pm 0.40$ & $4.31 \pm 0.06$ & $1.03 \pm 0.59$ \\
\hline
\end{tabular}

The number of moles of TDI and HDI bound in both HSA and Hb increased with increasing concentration of TDI and HDI used. On a per mole basis, HSA was three times more reactive to both TDI and $\mathrm{HDI}$ than $\mathrm{Hb}$ at all $\mathrm{dNCO} /$ protein conjugation ratios. These results agree with our earlier findings with MDI-HSA and MDI-Hb conjugates, where HSA was more reactive to MDI than $\mathrm{Hb}$. This could be a result of the structural differences between HSA and Hb. Hemoglobin, with four subunits (two alpha and two beta) and the iron containing porphyrin ring, may mask potential binding sites thus affecting its reactivity with dNCOs. This contrasts sharply with 
HSA, a single polypeptide with 585 residues containing 17 pairs of disulfide bridges and 1 free cysteine. TDI was five times more reactive to HSA than HDI and 4 times more reactive to $\mathrm{Hb}$ than $\mathrm{HDI}$. The extent of TDI conjugation to both $\mathrm{HSA}$ and $\mathrm{Hb}$ was similar to our previous results with MDI, both of which are aromatic isocyanates $^{59}$. TDI is reported to be have a higher rate constant than MDI in their reaction with nucleophiles such as alcohols.

\subsubsection{Cross-linking in TDI-HSA:TNBS assay}

The extent of cross-linking in TDI-HSA was evaluated using the TNBS assay that measures the loss of primary amine reactivity. Table 5.4 shows a concentrationdependent loss of available primary amines with increasing TDI and HDI concentrations and, thus, an increase in the amount of dNCO cross-linking.

Table 5.4 Cross-linking in TDI/HDI-HSA using the TNBS assay.

\begin{tabular}{|l|l|l|l|}
\hline $\begin{array}{l}\text { dNCO: protein } \\
\text { molar ratio }\end{array}$ & \multicolumn{4}{|l|}{ Loss of TNBS Amine reactivity (\%) } \\
\hline & MDI: HSA & HDI: HSA & 2,4-TDI: HSA \\
\hline Negative control & $0.00 \pm 0.00$ & $0.00 \pm 0.00$ & $0.00 \pm 0.00$ \\
\hline $\mathbf{1 : 1}$ & $16.58 \pm 5.21$ & $25.46 \pm 2.34$ & $18.04 \pm 3.98$ \\
\hline $\mathbf{5 : 1}$ & $24.96 \pm 2.14$ & $30.24 \pm 2.89$ & $31.47 \pm 3.57$ \\
\hline $\mathbf{1 0 : 1}$ & $39.71 \pm 4.51$ & $32.88 \pm 3.14$ & $39.92 \pm 4.14$ \\
\hline $\mathbf{4 0 : 1}$ & $57.88 \pm 7.07$ & $48.35 \pm 3.76$ & $62.42 \pm 4.18$ \\
\hline
\end{tabular}

A $62 \%$ loss of primary amine reactivity at 40:1 TDI:HSA and loss of $48 \%$ amine reactivity at 40:1 HDI:HSA was observed. At lower TDI and HDI concentrations (1:1- 
10:1 TDI/HDI:HSA), the degree of cross-linking was almost the same. However at 40:1 dNCO:HSA, TDI had a significantly higher degree of cross-linking than HDI.

\subsubsection{Gel electrophoresis: qualitative assessment of conjugation and crosslinking in TDI/HDI-HSA and TDI/HDI-Hb.}

Polyacrylamide gel electrophoresis was used to evaluate the extent of binding and cross-linking. Figure 5:1 shows an 8\% SDS- PAGE gel of $0.5 \mathrm{mg} / \mathrm{ml} \mathrm{HSA}$ reacted with TDI. Conjugation of TDI to HSA at a 1:1 molar ratio (Fig 5:1, lane 3) resulted in 68- and 71-kDa equivalent bands. This doublet, which was not observed with the HSA control, is a result of TDI conjugation, which results in an increase in the molecular weight of the HSA. At 5:1 TDI:HSA (Fig 5:1, lane 4), the 68-kDa HSA and the 71$\mathrm{kDa}$ bands are still observable with reduced resolution. At the higher 10:1 and 40:1 TDI/HSA conjugation ratios (lanes 5 and 6, respectively), broad bands that migrated like smaller molecules with leading edges of the bands at apparent masses of approximately 63 and $53 \mathrm{kDa}$ were observed. 


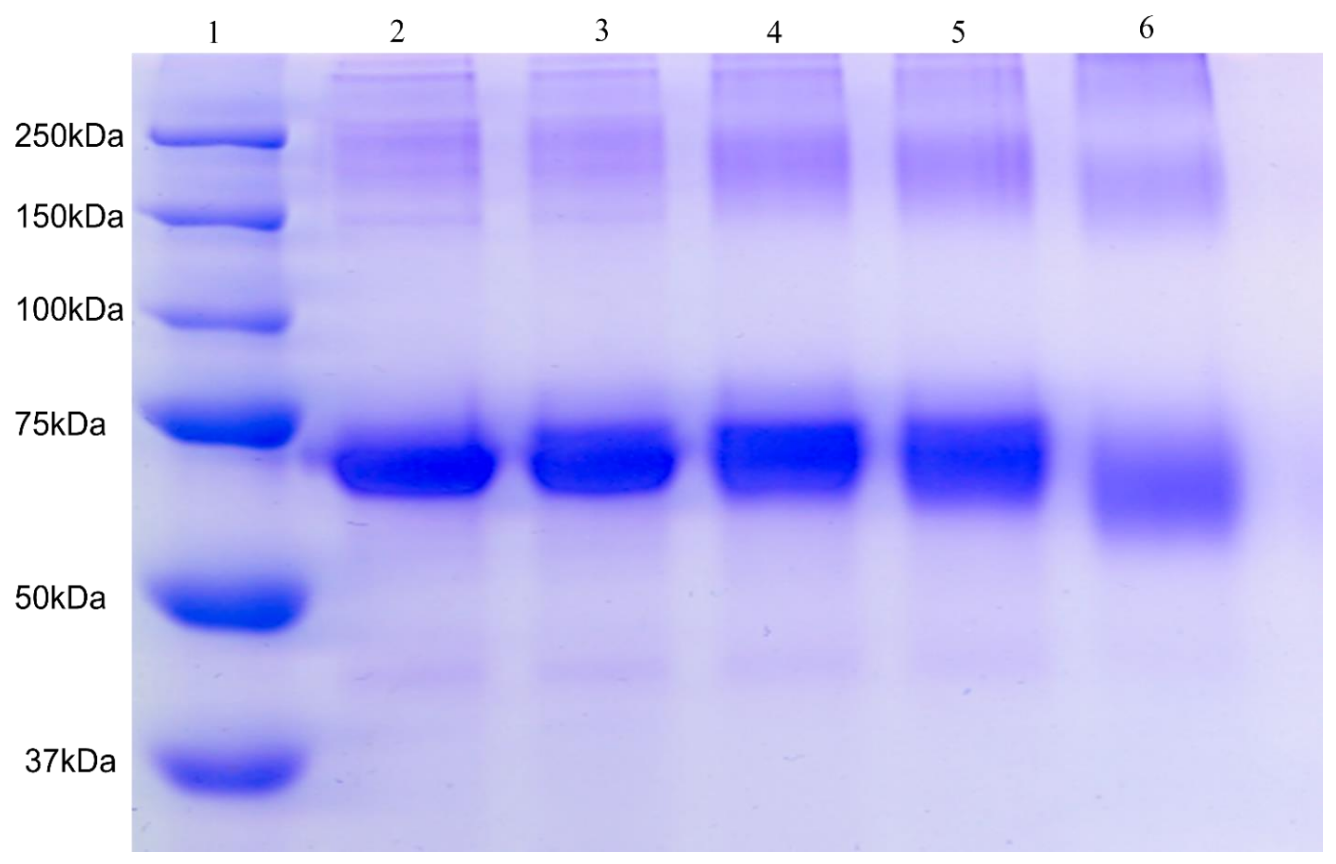

Figure 5.1: denaturing 8\% gel of TDI-HSA. Lane 1 is the molecular weight marker, lane 2 is HSA, and lanes 3, 4, 5, and 6 are 1:1, 5:1, 10:1, and 40:1 TDI: HSA respectively.

Figure 5:2 is an $8 \%$ gel of $0.5 \mathrm{mg} / \mathrm{ml} \mathrm{Hb}$ reacted with TDI. Denaturation of $\mathrm{Hb}$ resulted in the dissociation of the alpha and beta subunits that migrated at $15 \mathrm{kDa}$. A dark band and an unresolved smear of high-molecular-weight compounds at $30 \mathrm{kDa}$ and above suggests extensive inter-subunit cross-linking, and the intensity of this band increased with increasing TDI concentrations. A downward shift of the $15-\mathrm{kDa}$ subunits with increased TDI concentrations was also observed, similar to that found with the TDI-HSA conjugates. 


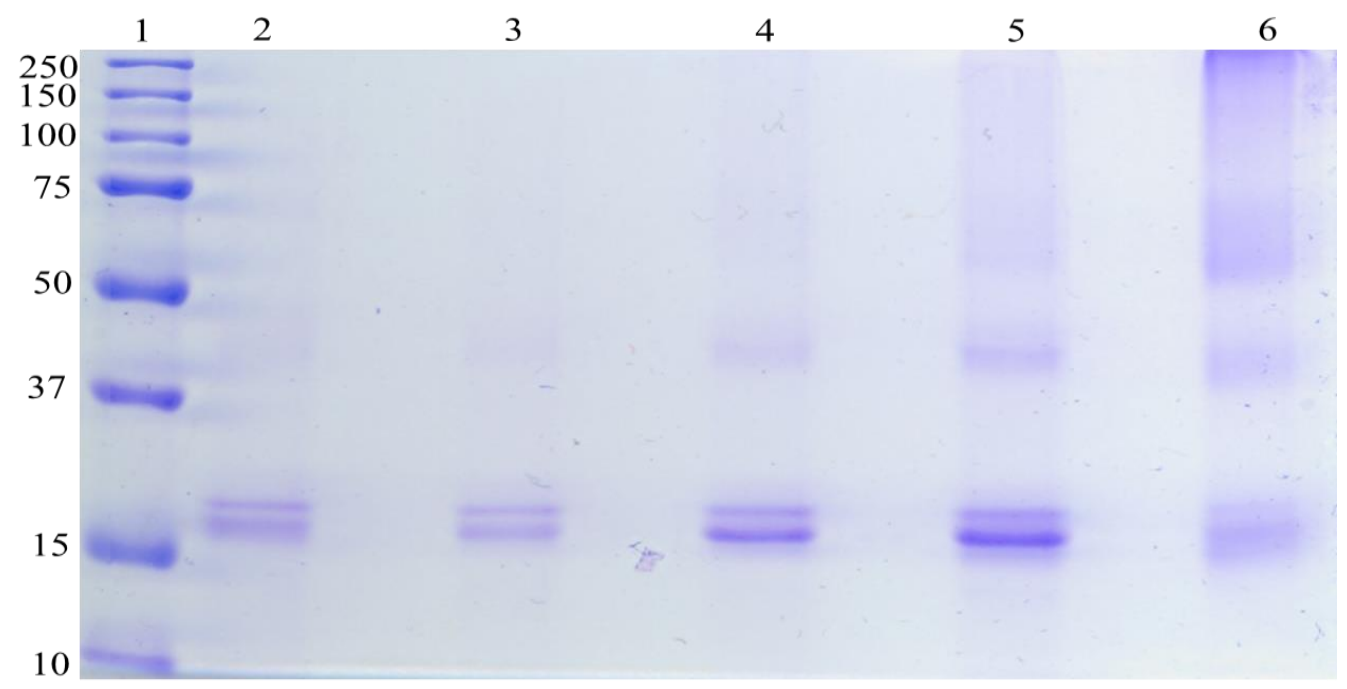

Figure 5.2: denaturing 12\% gel of TDI-Hb. Lane 1 is the molecular weight marker, lane 2 is $\mathrm{Hb}$, and lanes 3, 4, 5, and 6 are 1:1, 5:1, 10:1, and 40:1 TDI: Hb respectively.

Intermolecular cross-linking was observed in both dNCO-HSA and dNCO-Hb by the appearance of bands higher than the molecular weight of the native proteins.

Intramolecular cross-linking was also evidenced by a dNCO concentration-dependent downward shift in the leading edge of the protein band. Extensive intramolecular cross-linking increases conjugate mobility, presumably due to inhibition of complete denaturation under denaturing conditions and exclusion of intramolecular water under native conditions. The same observations were made with HDI-HSA and HDI-Hb conjugates (results not shown). 


\subsubsection{ELISA assessment of TDI-HSA /Hb.}

Binding of an IgG, 60G2 monoclonal antibody (mAb) raised against TDI-KLH to TDI-conjugated HSA and $\mathrm{Hb}$ was analyzed using an indirect enzyme-linked immunosorbent assay (ELISA) as described in section 2.3.11 ${ }^{103,104}$. Figure 5:3 below is a plot of absorbance readings at 10:1 and 40:1 of TDI conjugated HSA and $\mathrm{Hb}$. As expected, reactivity of conjugates to $60 \mathrm{G} 2$ was higher at 40:1 TDI-protein than 10:1 in both HSA and $\mathrm{Hb}$ conjugates. TDI-HSA was almost three times more reactive to 60G2 than TDI-Hb at both 40:1 and 10:1 TDI-protein.

Both TDI-HSA and TDI-Hb reacted to the anti-TDI-protein mAb, demonstrating the antigenicity of dNCO bound $\mathrm{Hb}$. TDI-Hb reactivity was almost $30 \%$ lower than that observed for TDI-HSA. This is in agreement with HPLC results where three times the amount of TDI bound to HSA than it did to Hb. Hettick et al identified 37 TDI binding sites on HSA. In our study, only 8 binding sites were identified on $\mathrm{Hb}$. These findings clearly indicate that the observed differences in antigenicity could be a function of number of dNCO bound per mole of protein and or availability in sera for dNCO conjugation. 
Comparing reactivity of TDI-HSA/Hb with 60G2

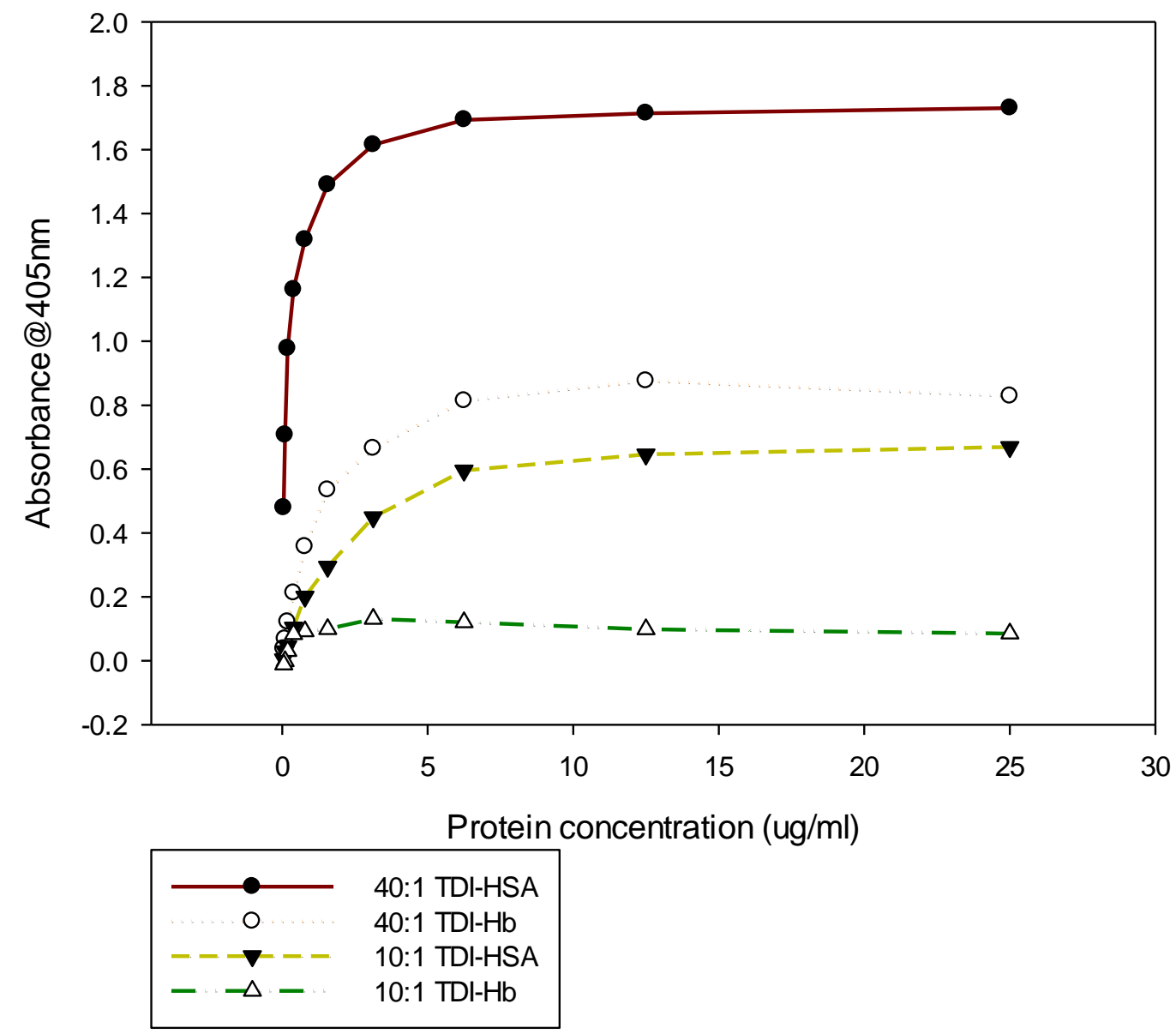

Figure 5.3: Immunoassay of TDI haptenated HSA and $\mathrm{Hb}$.

\subsection{CONCLUSION}

This is the first time that the specific TDI binding sites on $\mathrm{Hb}$ have been reported. Although there are similarities with our previous report on MDI binding sites, there are also differences between TDI and MDI binding sites. This is also the first time $\mathrm{Hb}$ - 
dNCO conjugates were demonstrated to be antigenic. Although their involvement in disease development can't be inferred from the observed antigenicity, it is important to evaluate the antigenicity of potentially endogenously haptenated proteins. Both qualitative and quantitative differences in TDI and HDI binding were observed between $\mathrm{Hb}$ and HSA conjugates. This suggests that the choice of the isocyanate for use in immunoassays has to be carefully considered. 


\section{CHAPTER 6}

\section{EVALUATING THE POTENTIAL FOR AN IgE INDEPENDENT MECHANISM THROUGH WHICH DIISOCYANATE ASTHMA DEVELOPS \\ 6.1 INTRODUCTION}

Although the ultimate immunogenic forms that lead to $\mathrm{dNCO}$ asthma are still unknown, dNCOs are low molecular weight chemical sensitizers that require haptenation to biomolecules in vivo to produce dNCO-specific immune sensitization. A number of biomolecules are targets for dNCO conjugation. Epithelial proteins are the major targets upon inhalation exposure ${ }^{105,106}$ whereas skin proteins are targeted upon skin exposure and both exposures can lead to OA. Kennedy et $a l^{107}$, using a rat model demonstrated that serum albumin is the major target for TDI conjugation in the blood.

The traditional mechanism for development of asthma involves recognition and endocytosis of antigens by antigen presenting cells. These cells then digest the antigens and associate the resultant peptides with major histocompatibility complex molecules (MHC). The MHC-peptide complex is then expressed on the cell surface together with co-stimulatory molecules, a requirement for successful $\mathrm{CD}^{+}{ }^{+} \mathrm{T}$-cell (Th0) activation ${ }^{106}$. Differentiation of TH0 to TH1 or TH2 subtypes depends on the nature of the antigen, cooperating cells, and cytokines. Allergenic antigens plus an environment rich in IL-4 from mast cells encourage Th2 phenotype development that leads to enhanced production of IL-4, IL-5, IL-3, and GM-CSF with minimal IFN- $\gamma$ production. The Th2 subtype is associated with $\operatorname{IgE}$ and eosinophilia and hence allergy. 
Only about $25 \%$ of dNCO asthmatic workers have detectable levels of IgE to dNCO HSA conjugates ${ }^{108}$. Although there is evidence that chemicals that cause respiratory sensitization provoke immune responses of the TH2 type, the mechanism of dNCO OA may possibly include cell-mediated and mixed reactions ${ }^{109,110}$. In a study by Bottomly et al ${ }^{111}$, female BALB/c mice sensitized to HDI developed HDI-specific IgG as well as elevated levels of IL-5, IL-13 and IFN- $\gamma$ on stimulation with HDImouse serum albumin, indicating a mixed TH1/TH2 immune response. Most importantly, these investigators observed that the sensitizing dose for antibody production was higher than that for airway inflammation and cytokine production. This suggests that different mechanisms dominate for the two outcomes. Del prete ${ }^{112}$ and Maestrelli ${ }^{113}$ demonstrated that the majority of T-cell clones from patients with TDI-induced asthma were $\mathrm{CD}^{+}$and capable of producing IL-5. David I. Bernstein et $\mathrm{al}^{114}$ demonstrated that repeated antigenic stimulation of $\mathrm{dNCO}$ asthmatic peripheral blood mononuclear cells (PBMC) in culture resulted in synthesis of tumor necrosis factor- $\alpha$ (TNF- $\alpha)$, a non-IgE dependent pro-inflammatory cytokine, and monocyte chemo-attractant protein-1, but not IL-4 or IL-5.

THP-1 cells were used in this study as a surrogate for antigen presenting cells and they were derived from the peripheral blood of a 1-year-old male with acute monocytic leukemia. They are single, round suspension cells with distinct monocytic markers ${ }^{115}$ with $\mathrm{Fc}$ and $\mathrm{C} 3 \mathrm{~b}$ receptors and lack surface and cytoplasmic immunoglobulins. THP-1 cells have advantages in studies over human primary monocytes-macrophages because 
they have a homogeneous genetic background, which minimizes the degree of variability in the cell phenotype $\mathrm{e}^{116,117}$.

The detection of dNCO specific antibodies in only a subset of dNCO asthmatics has been attributed to assay limitations and the potential for other non-IgE dependent mechanisms. Our previous work has been focused on characterization of dNCOprotein conjugates that are used in immunoassays for detection of dNCO specific antibodies with a view to standardize these immunoassays. We have also evaluated conjugates prepared in different conditions to evaluate the effect of preparative conditions on the nature of the conjugates. In this work, we hypothesize that MDI, apart from reacting with extracellular proteins, can also cross cell membranes intact and react with intracellular proteins. This will result is formation of intracellular conjugates which can possibly trigger cell mediated immune responses. To test this hypothesis, the aims of this work were: (a) to expose THP-1 cells to different concentrations of MDI, (b) use the HPLC method to analyze the membrane and cytoplasm fractions for MDI conjugation, and (c) identify proteins from MDI-exposed THP-1 cells using mass spectrometry.

\subsection{RESULTS AND DISCUSSION}

\subsubsection{Quantification of MDI in the cytoplasm}

THP-1 cells were incubated with different concentrations of MDI (dissolved in ethylene glycol dimethyl ether) and exposures were performed in Hanks' balanced solution for $4 \mathrm{~h}$ at $37^{\circ} \mathrm{C}$ and $5 \% \mathrm{CO}_{2}$. After washing three times, the cells were lysed using an ultra-sonicator and the cytoplasm fraction was extracted using cytoplasm 
extraction kits. The cytoplasm fraction was dialyzed against PBS buffer for $18 \mathrm{~h}$ to remove any MDI/MDA that was not conjugated to proteins. These samples were then hydrolyzed, extracted, and analyzed by HPLC as described in sections 2.3.6 and 2.3.7. Table 6.1 below shows the moles of MDI from the cytoplasm fraction.

Table 6.1 Moles of MDI from the cytoplasm fraction of MDI-exposed THP-1 cells

\begin{tabular}{|c|c|c|c|c|}
\hline \multicolumn{5}{|c|}{$\begin{array}{l}\text { CYTOPLASM FRACTION OBTAINED USING PROTEIN EXTRACTION } \\
\text { KITS }\end{array}$} \\
\hline $\begin{array}{l}\text { MDI } \\
\text { concentration } \\
(\mu \mathrm{M})\end{array}$ & $\begin{array}{l}\text { Viability post } \\
\text { exposure (\%) }\end{array}$ & $\begin{array}{l}\text { Protein } \\
\text { conc }(\mathrm{mg} / \mathrm{ml})\end{array}$ & $\begin{array}{l}\mu \mathrm{M} \text { MDI } \\
\text { Bound }\end{array}$ & $\begin{array}{l}\% \text { MDI of dose } \\
\text { bound }\end{array}$ \\
\hline 0 & $80.20 \pm 1.23$ & $3.15 \pm 0.23$ & $0.00 \pm 0.00$ & $0.00 \pm 0.00$ \\
\hline 5 & $80.20 \pm 3.21$ & $3.33 \pm 0.36$ & $0.44 \pm 0.06$ & $8.87 \pm 0.06$ \\
\hline 10 & $78.67 \pm 1.02$ & $2.37 \pm 0.28$ & $1.01 \pm 0.08$ & $10.13 \pm 0.08$ \\
\hline 25 & $80.87 \pm 4.92$ & $2.28 \pm 0.61$ & $2.56 \pm 1.36$ & $10.22 \pm 1.36$ \\
\hline 50 & $83.07 \pm 2.42$ & $1.67 \pm 0.53$ & $4.24 \pm 0.03$ & $8.49 \pm 0.03$ \\
\hline 100 & $79.40 \pm 3.12$ & $1.68 \pm 0.49$ & $8.94 \pm 1.13$ & $8.94 \pm 1.13$ \\
\hline
\end{tabular}

These results show that MDI does cross THP-1 cell membranes and react with intracellular proteins. The amount of MDI conjugated increased with increasing concentration of MDI exposed. The amount of MDI that gets into the cell and conjugates to the cytoplasm fraction varied slightly from $8.49 \%$ to $10.22 \%$ of the exposure MDI dose. In our previous work with MDI-HSA, the percentage of MDI conjugated to HSA varied from $22.75 \%$ to $70 \%$ with the highest percentage of MDI conjugation observed at the lowest MDI exposure. MDI exposure over the $4 \mathrm{~h}$ exposure time did not significantly affect the viability of the THP-1 cells. The amount of extracted protein quantified using nano drop absorbance at $280 \mathrm{~nm}$ decreased with increasing concentration of MDI. Two possible explanations can explain this reduction in protein content with increasing concentration of MDI; (i) extensive MDI 
conjugation may significantly reduce solubility of proteins in the extraction buffers used. This phenomenon was observed with MDI conjugated HSA and Hb where the conjugates tend to precipitate out of solution with time after conjugation, (ii) MDIconjugation may interfere with protein absorbance at $280 \mathrm{~nm}$ compromising the protein quantification.

\subsubsection{Quantification of MDI in the cell membrane fraction}

The membrane fraction of MDI exposed THP-1 cells consist of the plasma membrane and intracellular organelle membranes. These were extracted using membrane protein extraction kits, dialyzed against PBS buffer using 12-14 000 MWCO membranes. The dialyzed samples were hydrolyzed, extracted and analyzed for MDI using HPLC as described in section 2.3.6 and 2.3.7. Table 6.2 shows the amount of MDI bound to the membrane fraction. As expected, the amount of MDI bound to the membrane fraction increased with increasing amount of MDI used. MDI binding in the membrane fraction was less than that obtained from the cytoplasm fraction. It is also important to note that the protein content was significantly lower in the membrane fraction compared to the cytoplasm fraction as well. 
Table 6.2. Moles of MDI from the membrane fraction of MDI-exposed THP-1 cells

\begin{tabular}{|c|c|c|c|c|}
\hline \multicolumn{5}{|c|}{$\begin{array}{l}\text { MEMBRANE FRACTION OBTAINED USING PROTEIN EXTRACTION } \\
\text { KITS }\end{array}$} \\
\hline $\begin{array}{l}\text { MDI conc } \\
\text { (uM) }\end{array}$ & $\begin{array}{l}\text { Viability post } \\
\text { exposure }(\%)\end{array}$ & $\begin{array}{l}\text { Protein conc } \\
(\mathrm{mg} / \mathrm{ml})\end{array}$ & $\begin{array}{l}\mathrm{uM} \text { MDI } \\
\text { Bound }\end{array}$ & $\begin{array}{l}\% \text { MDI dose } \\
\text { bound }\end{array}$ \\
\hline 0 & $82.07 \pm 0.89$ & $0.22 \pm 0.03$ & $0.00 \pm 0.00$ & $0.00 \pm 0.00$ \\
\hline 5 & $87.55 \pm 0.07$ & $0.28 \pm 0.02$ & $0.04 \pm 0.01$ & $0.84 \pm 0.10$ \\
\hline 10 & $89.80 \pm 3.25$ & $0.20 \pm 0.05$ & $0.06 \pm 0.01$ & $0.62 \pm 0.11$ \\
\hline 25 & $83.63 \pm 4.61$ & $0.19 \pm 0.07$ & $0.31 \pm 0.03$ & $1.23 \pm 0.06$ \\
\hline 50 & $79.87 \pm 4.38$ & $0.24 \pm 0.03$ & $0.45 \pm 0.19$ & $0.90 \pm 0.38$ \\
\hline 100 & $78.80 \pm 4.52$ & $0.10 \pm 0.11$ & $1.14 \pm 0.44$ & $1.14 \pm 0.45$ \\
\hline
\end{tabular}

\subsubsection{Evaluating the effect of exposure time on the extent of MDI binding}

THP-1 cells were exposed to $100 \mu \mathrm{M}$ MDI for $30 \mathrm{~min}, 1 \mathrm{~h}, 2 \mathrm{~h}$, and $4 \mathrm{~h}$. Cells were

processed as described in section 7.4 and both the cytoplasm and membrane fractions were analyzed for MDI binding. Table 6.3 shows the amount of MDI bound in the cytoplasm fraction as a function of time. There is no significant change in MDI binding as exposure time is changed from 0.5 to $4 \mathrm{~h}$. The kinetics of MDI entry into cells and subsequent binding to the cytoplasm is complete within $30 \mathrm{~min}$. Table 6.4 shows MDI binding in the membrane fraction. As was observed in the cytoplasm fraction, there was no significant change in MDI binding in the membrane fraction with time. 
Table 6.3 Effect of exposure time on MDI binding in the cytoplasm fraction

\begin{tabular}{|l|l|l|l|}
\hline \multicolumn{4}{|l|}{ CYTOPLASM FRACTION } \\
\hline MDI $(\mu \mathrm{M})$ & Viab $(\%)$ & $\begin{array}{l}\mu \text { M MDI } \\
\text { Bound }\end{array}$ & $\%$ MDI binding \\
\hline 30 mins & $85.77 \pm 1.92$ & $11.43 \pm 2.23$ & $11.43 \pm 2.23$ \\
\hline 1 hour & $88.90 \pm 1.74$ & $10.68 \pm 1.63$ & $10.68 \pm 1.63$ \\
\hline 2 hours & $83.63 \pm 1.87$ & $9.21 \pm 4.98$ & $9.21 \pm 4.98$ \\
\hline 4 hours & $86.30 \pm 1.13$ & $10.74 \pm 0.46$ & $10.74 \pm 0.46$ \\
\hline
\end{tabular}

Table 6.4. Effect of exposure time on MDI binding in the membrane fraction

\begin{tabular}{|l|l|l|l|}
\hline \multicolumn{4}{|l|}{ MEMBRANE FRACTION } \\
\hline MDI $(\mu \mathrm{M})$ & Viab $(\%)$ & $\begin{array}{l}\mu \mathrm{M} \text { MDI } \\
\text { Bound }\end{array}$ & $\%$ MDI binding \\
\hline $30 \mathrm{~min}$ & $85.77 \pm 1.92$ & $1.04 \pm 0.29$ & $1.04 \pm 0.29$ \\
\hline 1 hour & $88.90 \pm 1.74$ & $0.97 \pm 0.52$ & $0.97 \pm 0.52$ \\
\hline 2 hours & $83.63 \pm 1.87$ & $1.01 \pm 0.47$ & $1.01 \pm 0.47$ \\
\hline 4 hours & $86.30 \pm 1.13$ & $1.04 \pm 0.32$ & $1.04 \pm 0.32$ \\
\hline
\end{tabular}

\subsubsection{Control experiments}

Several control experiments were performed to understand the mechanism of entry of

MDI in the cell as well as to confirm that the MDI that was detected in both the membrane and cytoplasm fractions was protein bound and not a result of hydrolyzed 
MDA that was not sufficiently washed away. The following control experiments were therefore performed:

(i) Co-incubation of THP-1 cells with MDI and cytochalasin D

To understand the mechanism of entry of MDI into cells, THP-1 cells were incubated with cytochalasin D for $1 \mathrm{~h}$ and incubated with $50 \mu \mathrm{M}$ MDI for 4 additional hours. Cytochalasin D is a microtubule inhibitor that inhibits active uptake of substances by cells.

(ii) Co-incubation with MDA

To test the effectiveness of the washing steps to get rid of any residual MDA resulting from the hydrolysis of MDI, THP-1 cells were incubated with $50 \mu \mathrm{M}$ MDA and analyzed to see if free (non-protein bound) MDA is detected in the resultant cytoplasm or membrane fractions.

(iii) Co-incubation with ethylene glycol dimethyl ether (EGDE)

Ethylene glycol dimethyl ether was the solvent used to dissolve the MDI before exposure to the THP-1 cells. The effect of the solvent on cell viability was evaluated.

Tables 6.5 and 6.6 show the amount of MDI detected in the cytoplasm and membrane fraction of control exposures described above. As table 6.5 shows, there was no difference in the amount of MDI binding in the cytoplasm between THP-1 cells exposed to just $50 \mu \mathrm{M}$ MDI and those co-incubated with $50 \mu \mathrm{M}$ MDI and $10 \mu \mathrm{M}$ cytochalasin D. This indicates that the entry of MDI into cells is a passive process that 
does not require energy. There was however a decrease in MDI binding to the membrane fraction when THP-1 cells were co-incubated with cytochalasin D. Coincubation of THP-1 cells with MDA did not result in detection of MDA in the cell fractions. This means the washing steps employed post exposure were sufficient to remove any MDA that was not bound to proteins. The EGDE does not significantly affect cell viability.

Table 6.5 Amount of MDI detected in the cytoplasm fraction of control exposures

\begin{tabular}{|l|l|l|l|}
\hline \multicolumn{4}{|l|}{ Cytoplasm fraction from exposure controls } \\
\hline Sample & Viab $(\%)$ & $\mu \mathrm{M}$ MDI Bound & $\%$ MDI binding \\
\hline $\begin{array}{l}\text { THP-1+10 } \mu \mathrm{M} \text { Cytochalasin } \\
\text { D }+50 \mu \mathrm{M} \text { MDI }\end{array}$ & $75.22 \pm 4.50$ & $4.06 \pm 0.62$ & $8.12 \pm 1.21$ \\
\hline THP-1+ 50 $\mu \mathrm{M}$ MDI & $83.07 \pm 2.42$ & $4.24 \pm 0.03$ & $8.49 \pm 0.03$ \\
\hline THP-1 and 50 $\mu \mathrm{M}$ MDA & $80.90 \pm 1.23$ & $0.00 \pm 0.00$ & $0.00 \pm 0.00$ \\
\hline THP-1 and 1\% EGDE & $89.65 \pm 1.56$ & $0.00 \pm 0.00$ & $0.00 \pm 0.00$ \\
\hline
\end{tabular}

Table 6.6 Amount of MDI detected in the membrane fraction of control exposures

\begin{tabular}{|c|c|c|c|}
\hline \multicolumn{4}{|c|}{ Membrane fraction from exposure controls } \\
\hline Sample & Viab $(\%)$ & $\mu \mathrm{M}$ MDI Bound & $\%$ MDI binding \\
\hline $\begin{array}{l}\text { THP-1+10 } \mu \text { M Cytochalasin } \\
\text { D }+50 \mu \mathrm{M} \text { MDI }\end{array}$ & $75.22 \pm 4.50$ & $0.26 \pm 0.04$ & $0.52 \pm 0.08$ \\
\hline $\mathrm{THP}-1+50 \mu \mathrm{M} \mathrm{MDI}$ & $83.07 \pm 2.42$ & $0.45 \pm 0.19$ & $0.90 \pm 0.38$ \\
\hline THP- 1 and $50 \mu \mathrm{M}$ MDA & $80.90 \pm 1.23$ & $0.00 \pm 0.00$ & $0.00 \pm 0.00$ \\
\hline THP-1 and $1 \%$ EGDE & $89.65 \pm 1.56$ & $0.00 \pm 0.00$ & $0.00 \pm 0.00$ \\
\hline
\end{tabular}




\subsubsection{Detection of MDI in specific SDS gel bands from MDI exposed THP-1 cells}

An alternative approach to confirm that the MDI detected in the cytoplasm fraction was protein bound was employed and involved resolution of proteins from the cytoplasm fraction using one-dimensional SDS gel electrophoresis. The resolved protein bands were excised, hydrolyzed and the resultant MDA extracted and analyzed by HPLC. Figure 6.1 shows an SDS gel obtained with the cytoplasm fraction. There are too many protein bands to clearly resolve individual proteins from a onedimensional gel, however, 13 bands numbered 1-13 were selected for HPLC analysis of MDA after acid hydrolysis as previously described (Figure 6.1). These bands were excised and after analysis, 11 of the 13 bands had detectable levels of MDI. Table 6.7 shows the amount of MDI that was quantified from the 13 bands excised from the cytoplasm fraction. These results further confirm that the MDI that was detected in the cytoplasm fraction was protein bound and MDI binding seems to be non-selective with the more abundant proteins (darker bands) having the higher amount of MDI bound. 40: 1 MDI: HSA was run in parallel as a control and as can be seen three bands $(a, b$, and $c)$ were visible and there were excised and analyzed for MDI as well. As expected, band $\mathrm{c}$, which was shifted further down relative to unconjugated HSA as a result of extensive MDI conjugation, had a very high amount of MDI. Band b, which most likely arises from a combination of MDI binding and extensive intermolecular cross-linking, also had a detectable amount of MDI conjugated. 


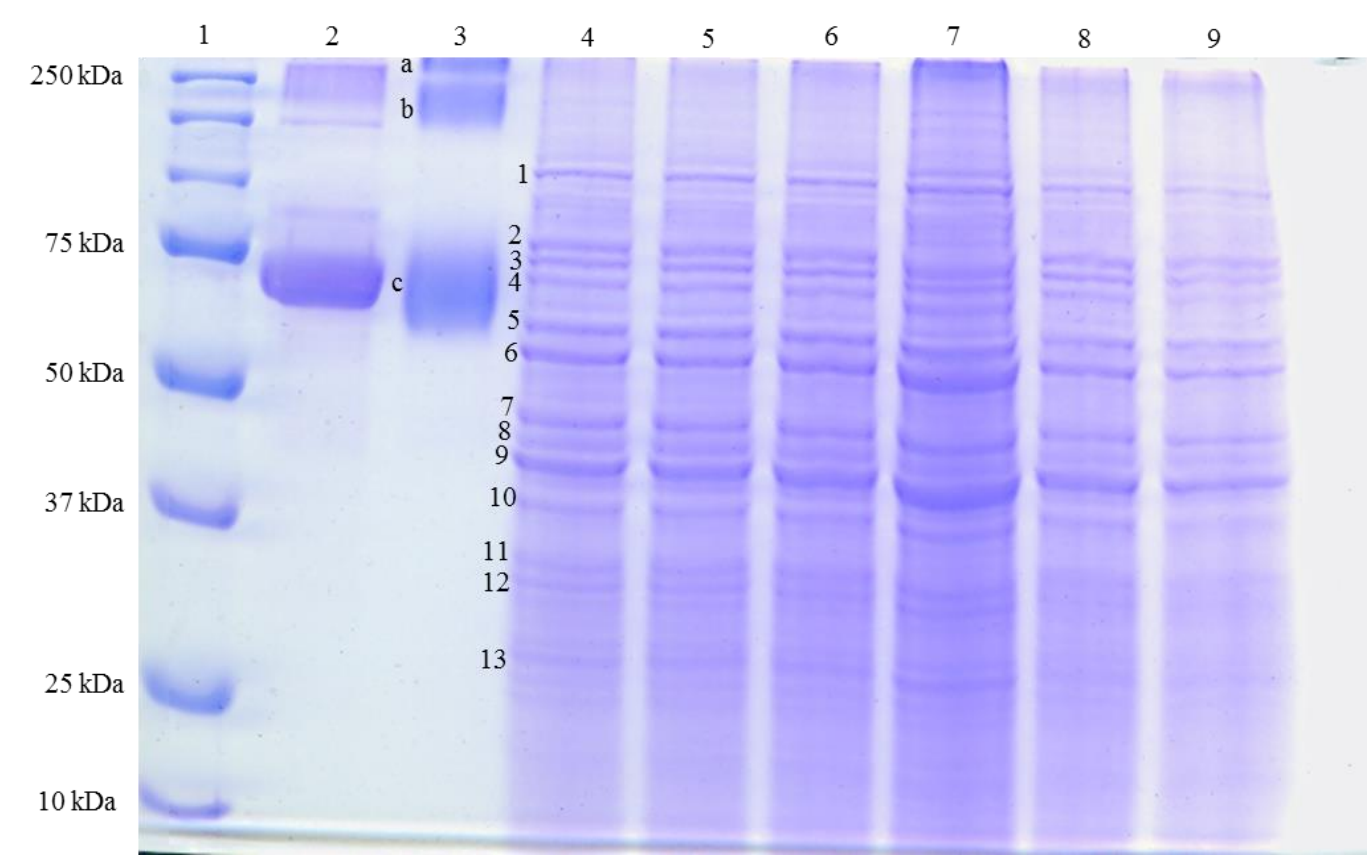

Figure 6.1. Resolution of THP-1 Cytoplasm proteins. A $12 \%$ denaturing gel of MDI exposed THP-1 cells' cytoplasm fraction. Lane 1 is the molecular weight marker, lane 2 is HSA, lanes 3 is 40:1 MDI: HSA, 4 is unconjugated THP-1 cytoplasm and lanes 59 are replicates of the cytoplasm fraction exposed to $100 \mu \mathrm{M} \mathrm{MDI}$. 
Table 6.7. MDI quantified from gel bands from the cytoplasm fraction

\begin{tabular}{|l|l|}
\hline Sample & MDA conc $(\mathbf{n g} / \mathbf{m l})$ \\
\hline THP1 1:40 HSA:MDI a & 0.00 \\
\hline THP1 1:40 HSA:MDI b & 55.89 \\
\hline THP1 1:40 HSA:MDI c & 107.84 \\
\hline THP1 Band 1 & 4.07 \\
\hline THP1 Band 2 & 5.61 \\
\hline THP1 Band 3 & 5.17 \\
\hline THP1 Band 4 & 6.15 \\
\hline THP1 Band 5 & 10.77 \\
\hline THP1 Band 6 & 7.43 \\
\hline THP1 Band 7 & 10.69 \\
\hline THP1 Band 8 & 0.00 \\
\hline THP1 Band 9 & 16.27 \\
\hline THP1 Band 10 & 0.00 \\
\hline THP1 Band 11 & 5.51 \\
\hline THP1 Band 12 & 7.11 \\
\hline THP1 Band 13 & 6.38 \\
\hline
\end{tabular}

\subsubsection{Identification of MDI bound proteins from bands with detectable MDI}

The bands from the cytoplasm fraction were also analyzed by proteomic mass spectrometry to identify the proteins in each band. This experiment was meant to 
identify proteins that were present in the gel bands from the cytoplasm of MDI exposed THP-1 cells. There is no difference in the protein content between exposed and unexposed cells and the protein identification did not detect MDI- bound peptides. Table 6.8 is a list of all the proteins that were identified. Because this is a onedimensional gel, there are several proteins that co-migrate in each band.

Table 6.8. The list of proteins identified from the 13 bands excised from the cytoplasm fraction

\begin{tabular}{|c|c|}
\hline $\begin{array}{l}\text { Protein } \\
\text { Band }\end{array}$ & Proteins identified \\
\hline 1 & $\begin{array}{l}\text { Alpha actinin } 4, \text { Neutral alpha glucosidase, Ubiquitin like modifier } \\
\text { activating enzyme }\end{array}$ \\
\hline 2 & $\begin{array}{l}\text { Endoplasmin OS Macaca fascicularis, Heterogeneous nuclear } \\
\text { ribonucleoprotein, Elongation factor 2, Alpha actinin 1, Transitional } \\
\text { endoplasmic reticulum ATPase }\end{array}$ \\
\hline 3 & $\begin{array}{l}\text { Heat shock protein HSP } 90 \text { beta OS, Heat shock protein HSP } 90 \text { alpha } \\
\text { OS, Calnexin OS, Far upstream element binding protein } 2 \text { OS }\end{array}$ \\
\hline 4 & $\begin{array}{l}78 \mathrm{kDa} \text { glucose regulated protein OS, Ezrin OS, Heat shock protein HSP } \\
90 \text { beta, X ray repair cross complementing protein } 5 \text { OS }\end{array}$ \\
\hline 5 & $\begin{array}{l}\text { Heat shock cognate } 71 \mathrm{kDa} \text { protein OS, Moesin OS, Stress } 70 \text { protein } \\
\text { mitochondrial OS, Annexin A6 OS, Aminopeptidase B OS, Adenylyl } \\
\text { cyclase associated protein } 1 \text { OS Pongo abelii, Heat shock protein } 75 \mathrm{kDa} \\
\text { mitochondrial OS, CTP synthase } 1 \text { OS, Serum albumin OS Bos taurus }\end{array}$ \\
\hline 6 & $\begin{array}{l}\text { Protein disulfide isomerase OS, Adenylyl cyclase associated protein } 1 \text { OS } \\
\text { Pongo abelii, alreticulin OS Macaca fuscata fuscata, Pyruvate kinase } \\
\text { isozymes M1 M2 OS, Nucleolin OS Pongo abelii, Pyruvate kinase } \\
\text { isozyme M1 OS Pongo abelii, Catalase OS, WD repeat containing protein } \\
1 \text { OS } \\
\text { Dolichyl diphosphooligosaccharide protein glycosyltransferase subunit } 2 \\
\text { OS, WD repeat containing protein 1, T complex protein } 1 \text { subunit zeta } \\
\text { OS, Heterogeneous nuclear ribonucleoprotein L OS }\end{array}$ \\
\hline
\end{tabular}




\begin{tabular}{|l|l|}
\hline 7 & $\begin{array}{l}\text { Adenylyl cyclase associated protein 1, Tubulin alpha 1B chain OS } \\
\text { Meriones unguiculatus, Protein disulfide isomerase A3 OS Pongo abelii, } \\
\text { Calreticulin OS, Glucose 6 phosphate isomerase OS, T complex protein 1 } \\
\text { subunit delta OS Bos Taurus, Plastin 2 OS, Coronin 1A OS Mus } \\
\text { musculus, Pre mRNA processing factor 19 OS }\end{array}$ \\
\hline 8 & $\begin{array}{l}\text { Alpha enolase OS Pongo abelii, Elongation factor 1 alpha 1, Actin muscle } \\
\text { OS Pisaster ochraceus, Actin cytoplasmic type 5 OS Xenopus laevis, } \\
\text { Adenylyl cyclase associated protein 1 OS Pongo abelii, Obg like ATPase } \\
\text { 1 OS Bos Taurus, Ribonuclease inhibitor OS Pan troglodytes, 6 } \\
\text { phosphogluconate dehydrogenase decarboxylating OS,Elongation factor } \\
\text { Tu mitochondrial OS, Nuclease sensitive element binding protein 1 OS } \\
\text { Bos Taurus, Eukaryotic initiation factor 4A I OS, 6 phosphogluconate } \\
\text { dehydrogenase decarboxylating OS Mus musculus, Rab GDP dissociation } \\
\text { inhibitor beta OS, Fumarate hydratase mitochondrial OS Macaca } \\
\text { fascicularis, Elongation factor 1 gamma OS Equus caballus, Tubulin beta } \\
5 \text { chain OS Bos taurus }\end{array}$ \\
\hline 9 & $\begin{array}{l}\text { Actin cytoplasmic type 5 OS Xenopus laevis PE, Elongation factor 1 } \\
\text { alpha 1 OS Gallus gallus, Phosphoglycerate kinase 1 OS Pan troglodytes, } \\
\text { Elongation factor 1 alpha 1 OS Equus caballus, 40S ribosomal protein SA } \\
\text { OS Taeniopygia guttata, Heterogeneous nuclear ribonucleoprotein D0 OS, } \\
\text { Interleukin enhancer binding factor 2 OS Mus musculus }\end{array}$ \\
\hline 10 & $\begin{array}{l}\text { Fructose bisphosphate aldolase A OS, Actin cytoplasmic A4 OS Bombyx } \\
\text { mori, Elongation factor 1 delta OS, Guanine nucleotide binding protein G } \\
\text { i subunit alpha 2 OS, Activator of 90 kDa heat shock protein ATPase } \\
\text { homolog 1 OS, Actin related protein 3 OS Pongo abelii, Protein disulfide } \\
\text { isomerase A6 OS }\end{array}$ \\
\hline 11 & $\begin{array}{l}\text { Actin cytoplasmic 1 OS Xenopus laevis, 60S acidic ribosomal protein P0 } \\
\text { OS, Heterogeneous nuclear ribonucleoproteins A2 B1 OS Mus musculus, } \\
\text { LIM and SH3 domain protein 1, Alpha enolase OS Pongo abelii, DNA } \\
\text { apurinic or apyrimidinic site lyase OS, Pyridoxal kinase OS, Fructose 1 } 6 \\
\text { bisphosphatase 1 OS, Eukaryotic translation initiation factor 2 subunit 1, } \\
\text { Biliverdin reductase A, L lactate dehydrogenase B chain OS Macaca } \\
\text { fascicularis }\end{array}$ \\
\hline
\end{tabular}




\begin{tabular}{|l|l|}
\hline 12 & $\begin{array}{l}\text { Glyceraldehyde 3 phosphate dehydrogenase, L lactate dehydrogenase B } \\
\text { chain, Malate dehydrogenase cytoplasmic OS, Malate dehydrogenase } \\
\text { mitochondrial OS Bos Taurus, Tropomyosin alpha 3 chain OS Rattus } \\
\text { norvegicus, Heterogeneous nuclear ribonucleoproteins A2 B1 OS Pongo } \\
\text { abelii, DNA apurinic or apyrimidinic site lyase OS Mus musculus, } \\
\text { Heterogeneous nuclear ribonucleoprotein A1 OS Pan troglodytes, DNA } \\
\text { apurinic or apyrimidinic site lyase, Serine threonine protein phosphatase } \\
\text { 2A catalytic subunit alpha isoform OS Oryctolagus cuniculus, Annexin } \\
\text { A1 OS Pongo abelii }\end{array}$ \\
\hline 13 & $\begin{array}{l}\text { Actin cytoplasmic 1 OS Xenopus tropicalis, Carbonic anhydrase 2 OS, 14 } \\
\text { 3 3 protein zeta delta OS Pongo abelii, 14 3 3 protein beta alpha OS, Heat } \\
\text { shock protein beta 1 OS, Phosphoglycerate mutase 1 OS Rattus } \\
\text { norvegicus, 6 phosphogluconolactonase OS, 14 3 3 like protein OS Pisum } \\
\text { sativum PE 2 SV 1, ADP ATP translocase 1 OS Bos Taurus, Adenylate } \\
\text { kinase 2 mitochondrial OS Pongo abelii, Catechol O methyltransferase } \\
\text { OS, Peroxiredoxin 4 OS, 6 phosphogluconolactonase OS Mus musculus, } \\
\text { Eukaryotic translation initiation factor 6 OS, Purine nucleoside } \\
\text { phosphorylase OS, U2 small nuclear ribonucleoprotein A OS. }\end{array}$ \\
\hline
\end{tabular}

\subsection{CONCLUSION}

Taken together, these findings confirm that MDI crosses cell membranes and react with intracellular proteins. It also reacts with membrane proteins. The entry of MDI into the cell is a passive process because co-incubation of THP-1 cells with cytochalasin D, a microtubule inhibitor, did not change the amount of MDI conjugation in the cytoplasm. This passive entry of MDI is a fast process that takes place in minutes rather than hours and it is plausible that MDI sensitization and the ultimate development of dNCO asthma can proceed through a cell-mediated mechanism independent of the production of dNCO specific antibodies. There is 
ongoing work that involves running 2-dimensional gel electrophoresis and western blot analysis using an MDI specific monoclonal antibody (IgG). 


\section{Reference List}

1. Munn, S. J.; Hansen, B. G. EU risk assessment: science and policy. Toxicology 2002, 181-182, 281-285.

2. Piirila, P. L.; Nordman, H.; Keskinen, H. M.; Luukkonen, R.; Salo, S. P.; Tuomi, T. O.; Tuppurainen, M. Long-term follow-up of hexamethylene diisocyanate-, diphenylmethane diisocyanate-, and toluene diisocyanate-induced asthma. Am. J. Respir. Crit Care Med. 2000, 162 (2 Pt 1), 516-522.

3. Frick, M.; Bjorkner, B.; Hamnerius, N.; Zimerson, E. Allergic contact dermatitis from dicyclohexylmethane-4,4'-diisocyanate. Contact Dermatitis 2003, 48 (6), 305-309.

4. Krone, C. A.; Klingner, T. D. Isocyanates, polyurethane and childhood asthma. Pediatr. Allergy Immunol. 2005, 16 (5), 368-379.

5. Ulrich, H. Chemistry and technology of isocyanates; Wiley New York: 1996.

6. Clark, R. L.; Bugler, J.; Paddle, G. M.; Chamberlain, J. D.; Allport, D. C. A 17-year epidemiological study on changes in lung function in toluene diisocyanate foam workers. Int. Arch. Occup. Environ. Health 2003, 76 (4), 295-301.

7. Karol, M. H.; Hauth, B. A.; Riley, E. J.; Magreni, C. M. Dermal contact with toluene diisocyanate (TDI) produces respiratory tract hypersensitivity in guinea pigs. Toxicol. Appl. Pharmacol. 1981, 58 (2), 221-230.

8. Petsonk, E. L.; Wang, M. L.; Lewis, D. M.; Siegel, P. D.; Husberg, B. J. Asthma-like symptoms in wood product plant workers exposed to methylene diphenyl diisocyanate. Chest 2000, 118 (4), 1183-1193.

9. Krone, C. A. Diisocyanates and nonoccupational disease: a review. Arch. Environ. Health 2004, 59 (6), 306-316.

10. LeSage, J.; Stanley, J.; Karoly, W. J.; Lichtenberg, F. W. Airborne methylene diphenyl diisocyanate (MDI) concentrations associated with the application of polyurethane spray foam in residential construction. $J$. Occup. Environ. Hyg. 2007, 4 (2), 145-155.

11. Crespo, J.; Galan, J. Exposure to MDI during the process of insulating buildings with sprayed polyurethane foam. Ann. Occup. Hyg. 1999, 43 (6), 415-419. 
12. Liljelind, I.; Norberg, C.; Egelrud, L.; Westberg, H.; Eriksson, K.; NylanderFrench, L. A. Dermal and inhalation exposure to methylene bisphenyl isocyanate (MDI) in iron foundry workers. Ann. Occup. Hyg. 2010, 54 (1), 31-40.

13. Robert, A.; Ducos, P.; Francin, J. M.; Marsan, P. Biological monitoring of workers exposed to 4,4'-methylenediphenyl diisocyanate (MDI) in 19 French polyurethane industries. Int. Arch. Occup. Environ. Health 2007, 80 (5), 412-422.

14. Wisnewski, A. V.; Xu, L.; Robinson, E.; Liu, J.; Redlich, C. A.; Herrick, C. A. Immune sensitization to methylene diphenyl diisocyanate (MDI) resulting from skin exposure: albumin as a carrier protein connecting skin exposure to subsequent respiratory responses. J. Occup. Med. Toxicol. 2011, 6, 6 .

15. Kimber, I.; Basketter, D. Thresholds, dose-response relationships and dose metrics in allergic contact dermatitis. Br. J. Dermatol. 2008, 159 (6), $1380-1381$.

16. Mapp, C. E.; Boschetto, P.; Maestrelli, P.; Fabbri, L. M. Occupational asthma. Am. J. Respir. Crit Care Med. 2005, 172 (3), 280-305.

17. Redlich, C. A.; Karol, M. H. Diisocyanate asthma: clinical aspects and immunopathogenesis. Int. Immunopharmacol. 2002, 2 (2-3), 213-224.

18. Ott, M. G.; Diller, W. F.; Jolly, A. T. Respiratory effects of toluene diisocyanate in the workplace: a discussion of exposure-response relationships. Crit Rev. Toxicol. 2003, 33 (1), 1-59.

19. Karol, M. H. Respiratory effects of inhaled isocyanates. Crit Rev. Toxicol. 1986, 16 (4), 349-379.

20. Matheson, J. M.; Johnson, V. J.; Vallyathan, V.; Luster, M. I. Exposure and immunological determinants in a murine model for toluene diisocyanate (TDI) asthma. Toxicol. Sci. 2005, 84 (1), 88-98.

21. Baur, X. Hypersensitivity pneumonitis (extrinsic allergic alveolitis) induced by isocyanates. J. Allergy Clin. Immunol. 1995, 95 (5 Pt 1), 1004-1010.

22. Charles, J.; Bernstein, A.; Jones, B.; Jones, D. J.; Edwards, J. H.; Seal, R. M.; Seaton, A. Hypersensitivity pneumonitis after exposure to isocyanates. Thorax 1976, 31 (2), 127-136. 
23. Hur, G. Y.; Koh, D. H.; Choi, G. S.; Park, H. J.; Choi, S. J.; Ye, Y. M.; Kim, K. S.; Park, H. S. Clinical and immunologic findings of methylene diphenyl diisocyanate-induced occupational asthma in a car upholstery factory. Clin. Exp. Allergy 2008, 38 (4), 586-593.

24. Butcher, B. T.; Salvaggio, J. E. Occupational asthma. J. Allergy Clin. Immunol. 1986, 78 (4 Pt 1), 547-556.

25. Bernstein, J. A. Overview of diisocyanate occupational asthma. Toxicology 1996, $111(1-3), 181-189$.

26. Wisnewski, A. V.; Redlich, C. A. Recent developments in diisocyanate asthma. Curr. Opin. Allergy Clin. Immunol. 2001, 1 (2), 169-175.

27. Chipinda, I.; Zhang, X. D.; Simoyi, R. H.; Siegel, P. D. Mercaptobenzothiazole allergenicity-role of the thiol group. Cutan. Ocul. Toxicol. 2008, 27 (2), 103-116.

28. Hettick, J. M.; Siegel, P. D. Determination of the toluene diisocyanate binding sites on human serum albumin by tandem mass spectrometry. Anal. Biochem. 2011, 414 (2), 232-238.

29. Maestrelli, P.; Boschetto, P.; Fabbri, L. M.; Mapp, C. E. Mechanisms of occupational asthma. J. Allergy Clin. Immunol. 2009, 123 (3), 531-542.

30. Mapp, C. E.; Miotto, D.; Boschetto, P. Occupational asthma. Med. Lav. 2006, 97 (2), 404-409.

31. Biagini, R. E.; Bernstein, I. L.; Gallagher, J. S.; Moorman, W. J.; Brooks, S.; Gann, P. H. The diversity of reaginic immune responses to platinum and palladium metallic salts. J. Allergy Clin. Immunol. 1985, 76 (6), 794-802.

32. Mapp, C. E. Agents, old and new, causing occupational asthma. Occup. Environ. Med. 2001, 58 (5), 354-60, 290.

33. Chan-Yeung, M. Assessment of asthma in the workplace. ACCP consensus statement. American College of Chest Physicians. Chest 1995, 108 (4), 1084-1117.

34. Karol, M. H.; Tollerud, D. J.; Campbell, T. P.; Fabbri, L.; Maestrelli, P.; Saetta, M.; Mapp, C. E. Predictive value of airways hyperresponsiveness and circulating $\operatorname{IgE}$ for identifying types of responses to toluene diisocyanate inhalation challenge. Am. J. Respir. Crit Care Med. 1994, 149 (3 Pt 1), 611-615. 
35. Park, H. S.; Lee, S. K.; Lee, Y. M.; Kim, S. S.; Nahm, D. H. Longitudinal study of specific antibodies to toluene diisocyanate (TDI)-human serum albumin (HSA) conjugate in patients with TDI-induced asthma. Korean J. Intern. Med. 2002, 17 (4), 249-251.

36. Jones, M. G.; Floyd, A.; Nouri-Aria, K. T.; Jacobson, M. R.; Durham, S. R.; Taylor, A. N.; Cullinan, P. Is occupational asthma to diisocyanates a non-IgE-mediated disease? J. Allergy Clin. Immunol. 2006, 117 (3), 663-669.

37. Jame, A. J.; Lackie, P. M.; Cazaly, A. M.; Sayers, I.; Penrose, J. F.; Holgate, S. T.; Sampson, A. P. Human bronchial epithelial cells express an active and inducible biosynthetic pathway for leukotrienes B4 and C4. Clin. Exp. Allergy 2007, 37 (6), 880-892.

38. Holgate, S. T.; Holloway, J.; Wilson, S.; Bucchieri, F.; Puddicombe, S.; Davies, D. E. Epithelial-mesenchymal communication in the pathogenesis of chronic asthma. Proc. Am. Thorac. Soc. 2004, 1 (2), 93-98.

39. Lemiere, C.; Malo, J. L.; Boutet, M. Reactive airways dysfunction syndrome due to chlorine: sequential bronchial biopsies and functional assessment. Eur. Respir. J. 1997, 10 (1), 241-244.

40. Ott, M. G.; Jolly, A. T.; Burkert, A. L.; Brown, W. E. Issues in diisocyanate antibody testing. Crit Rev. Toxicol. 2007, 37 (7), 567-585.

41. Wass, U.; Belin, L. Immunologic specificity of isocyanate-induced IgE antibodies in serum from 10 sensitized workers. J. Allergy Clin. Immunol. 1989, 83 (1), 126-135.

42. Venables, K. M.; Chan-Yeung, M. Occupational asthma. Lancet 1997, 349 (9063), 1465-1469.

43. Bernstein, D. I.; Jolly, A. Current diagnostic methods for diisocyanate induced occupational asthma. Am. J. Ind. Med. 1999, 36 (4), 459-468.

44. Bradding, P.; Walls, A. F.; Holgate, S. T. The role of the mast cell in the pathophysiology of asthma. J. Allergy Clin. Immunol. 2006, 117 (6), $1277-1284$.

45. Del Prete, G. F.; De, C. M.; D'Elios, M. M.; Maestrelli, P.; Ricci, M.; Fabbri, L.; Romagnani, S. Allergen exposure induces the activation of allergenspecific Th2 cells in the airway mucosa of patients with allergic respiratory disorders. Eur. J. Immunol. 1993, 23 (7), 1445-1449. 
46. Maestrelli, P.; Del Prete, G. F.; De, C. M.; D'Elios, M. M.; Saetta, M.; Di, S. A.; Mapp, C. E.; Romagnani, S.; Fabbri, L. M. CD8 T-cell clones producing interleukin-5 and interferon-gamma in bronchial mucosa of patients with asthma induced by toluene diisocyanate. Scand. J. Work Environ. Health 1994, 20 (5), 376-381.

47. Wisnewski, A. V.; Cain, H.; Magoski, N.; Wang, H.; Holm, C. T.; Redlich, C. A. Human gamma/delta T-cell lines derived from airway biopsies. Am. J. Respir. Cell Mol. Biol. 2001, 24 (3), 332-338.

48. Wisnewski, A. V.; Herrick, C. A.; Liu, Q.; Chen, L.; Bottomly, K.; Redlich, C. A. Human gamma/delta T-cell proliferation and IFN-gamma production induced by hexamethylene diisocyanate. J. Allergy Clin. Immunol. 2003, 112 (3), 538-546.

49. Kay, A. B.; Corrigan, C. J.; Frew, A. J. The role of cellular immunology in asthma. Eur. Respir. J. Suppl 1991, 13, 105s-112s.

50. Maestrelli, P.; O'Hehir, R. E.; Lamb, J. R.; Tsai, J. J.; Cromwell, O.; Kay, A. B. Antigen-induced neutrophil chemotactic factor from cloned human T lymphocytes. Immunology 1988, 65 (4), 605-609.

51. Finotto, S.; Fabbri, L. M.; Rado, V.; Mapp, C. E.; Maestrelli, P. Increase in numbers of CD8 positive lymphocytes and eosinophils in peripheral blood of subjects with late asthmatic reactions induced by toluene diisocyanate. Br. J. Ind. Med. 1991, 48 (2), 116-121.

52. Chan-Yeung, M.; Malo, J. L. Occupational asthma. N. Engl. J. Med. 1995, 333 (2), 107-112.

53. Whitehouse, C. M.; Dreyer, R. N.; Yamashita, M.; Fenn, J. B. Electrospray interface for liquid chromatographs and mass spectrometers. Anal. Chem. 1985, 57 (3), 675-679.

54. Fenn, J. B.; Mann, M.; Meng, C. K.; Wong, S. F.; Whitehouse, C. M. Electrospray ionization for mass spectrometry of large biomolecules. Science 1989, 246 (4926), 64-71.

55. Mhike, M.; Chipinda, I.; Hettick, J. M.; Simoyi, R. H.; Lemons, A.; Green, B. J.; Siegel, P. D. Characterization of methylene diphenyl diisocyanatehaptenated human serum albumin and hemoglobin. Anal. Biochem. 2013, 440 (2), 197-204. 
56. Takahashi, S.; Yamamura, T.; Kamo, M.; Satake, K. Regeneration of amino compounds from the 2, 4, 6-trinitrophenyl derivatives by treatment with hydrazine. Chemistry Letters 1984, (1), 127-130.

57. Snyder, S. L.; Sobocinski, P. Z. An improved 2,4,6-trinitrobenzenesulfonic acid method for the determination of amines. Anal. Biochem. 1975, 64 (1), 284-288.

58. Lemus, R.; Lukinskeine, L.; Bier, M. E.; Wisnewski, A. V.; Redlich, C. A.; Karol, M. H. Development of immunoassays for biomonitoring of hexamethylene diisocyanate exposure. Environ. Health Perspect. 2001, 109 (11), 1103-1108.

59. Mhike, M.; Chipinda, I.; Hettick, J. M.; Simoyi, R. H.; Lemons, A.; Green, B. J.; Siegel, P. D. Characterization of methylene diphenyl diisocyanatehaptenated human serum albumin and hemoglobin. Anal. Biochem. 2013, 440 (2), 197-204.

60. Lemons, A. R.; Siegel, P. D.; Mhike, M.; Law, B. F.; Hettick, J. M.; Bledsoe, T. A.; Nayak, A. P.; Beezhold, D. H.; Green, B. J. A murine monoclonal antibody with broad specificity for occupationally relevant diisocyanates. J. Occup. Environ. Hyg. 2014, 11 (2), 101-110.

61. Lemons, A. R.; Bledsoe, T. A.; Siegel, P. D.; Beezhold, D. H.; Green, B. J. Development of sandwich ELISAs for the detection of aromatic diisocyanate adducts. J. Immunol. Methods 2013, 397 (1-2), 66-70.

62. Ruwona, T. B.; Johnson, V. J.; Schmechel, D.; Simoyi, R. H.; Beezhold, D.; Siegel, P. D. Monoclonal antibodies against toluene diisocyanate haptenated proteins from vapor-exposed mice. Hybridoma (Larchmt.) 2010, 29 (3), 221-229.

63. Ruwona, T. B.; Johnson, V. J.; Hettick, J. M.; Schmechel, D.; Beezhold, D.; Wang, W.; Simoyi, R. H.; Siegel, P. D. Production, characterization and utility of a panel of monoclonal antibodies for the detection of toluene diisocyanate haptenated proteins. J. Immunol. Methods 2011, 373 (1-2), 127-135.

64. Tee, R. D.; Cullinan, P.; Welch, J.; Burge, P. S.; Newman-Taylor, A. J. Specific IgE to isocyanates: a useful diagnostic role in occupational asthma. J. Allergy Clin. Immunol. 1998, 101 (5), 709-715.

65. Wisnewski, A. V.; Stowe, M. H.; Cartier, A.; Liu, Q.; Liu, J.; Chen, L.; Redlich, C. A. Isocyanate vapor-induced antigenicity of human albumin. J. Allergy Clin. Immunol. 2004, 113 (6), 1178-1184. 
66. Park, H. S.; Park, J. N.; Kim, J. W.; Kim, S. K. Clinical and immunological evaluation of isocyanate-exposed workers. J. Korean Med. Sci. 1992, 7 (2), 122-127.

67. Sabbioni, G.; Dongari, N.; Schneider, S.; Kumar, A. Synthetic approaches to obtain amino acid adducts of 4,4'-methylenediphenyl diisocyanate. Chem. Res. Toxicol. 2012, 25 (12), 2704-2714.

68. Kennedy, A. L.; Brown, W. E. Isocyanates and lung disease: experimental approaches to molecular mechanisms. Occup. Med. 1992, 7 (2), 301329.

69. Brown, W. E.; Green, A. H.; Cedel, T. E.; Cairns, J. Biochemistry of proteinisocyanate interactions: a comparison of the effects of aryl vs. alkyl isocyanates. Environ. Health Perspect. 1987, 72, 5-11.

70. Kumar, A.; Dongari, N.; Sabbioni, G. New isocyanate-specific albumin adducts of 4,4'-methylenediphenyl diisocyanate (MDI) in rats. Chem. Res. Toxicol. 2009, 22 (12), 1975-1983.

71. Sepai, O.; Schutze, D.; Heinrich, U.; Hoymann, H. G.; Henschler, D.; Sabbioni, G. Hemoglobin adducts and urine metabolites of 4,4'methylenedianiline after 4,4'-methylenediphenyl diisocyanate exposure of rats. Chem. Biol. Interact. 1995, 97 (2), 185-198.

72. Sabbioni, G.; Schutze, D. Hemoglobin binding of bicyclic aromatic amines. Chem. Res. Toxicol. 1998, 11 (5), 471-483.

73. Pauluhn, J.; Brown, W. E.; Hext, P.; Leibold, E.; Leng, G. Analysis of biomarkers in rats and dogs exposed to polymeric methylenediphenyl diisocyanate (pMDI) and its glutathione adduct. Toxicology 2006, 222 (3), 202-212.

74. Sakai, T.; Morita, Y.; Kim, Y.; Tao, Y. X. LCГÇôMS determination of urinary toluenediamine in workers exposed to toluenediisocyanate. Toxicology letters 2002, 134 (1), 259-264.

75. Lemus, R.; Karol, M. H. Conjugation of haptens. Methods Mol. Med. 2008, $138,167-182$.

76. Zhao, X.; Suo, Y. Analysis of primary aromatic amines using precolumn derivatization by HPLC fluorescence detection and online MS identification. J. Sep. Sci. 2008, 31 (4), 646-658. 
77. Wallace, J. M.; Fox, P. F. Rapid spectrophotometric and fluorimetric methods for monitoring nitrogenous (proteinaceous) compounds in cheese and cheese fractions: a review. Food chemistry 1998, 62 (2), 217-224.

78. Toker, S. E.; Sagirli, O.; Cetin, S. M.; Onal, A. A new HPLC method with fluorescence detection for the determination of memantine in human plasma. J. Sep. Sci. 2011, 34 (19), 2645-2649.

79. Sabbioni, G.; Hartley, R.; Henschler, D.; Hollrigl-Rosta, A.; Koeber, R.; Schneider, S. Isocyanate-specific hemoglobin adduct in rats exposed to 4, 4'-methylenediphenyl diisocyanate. Chem. Res. Toxicol. 2000, 13 (2), 82-89.

80. Budnik, L. T.; Preisser, A. M.; Permentier, H.; Baur, X. Is specific IgE antibody analysis feasible for the diagnosis of methylenediphenyl diisocyanate-induced occupational asthma? Int. Arch. Occup. Environ. Health 2013, 86 (4), 417-430.

81. Skarping, G.; Dalene, M.; Littorin, M. 4,4'-Methylenedianiline in hydrolysed serum and urine from a worker exposed to thermal degradation products of methylene diphenyl diisocyanate elastomers. Int. Arch. Occup. Environ. Health 1995, 67 (2), 73-77.

82. Tse, C. S.; Pesce, A. J. Chemical characterization of isocyanate-protein conjugates. Toxicol. Appl. Pharmacol. 1979, 51 (1), 39-46.

83. Flack, S. L.; Fent, K. W.; Gaines, L. G.; Thomasen, J. M.; Whittaker, S. G.; Ball, L. M.; Nylander-French, L. A. Hemoglobin adducts in workers exposed to 1,6-hexamethylene diisocyanate. Biomarkers 2011, 16 (3), 261-270.

84. Wisnewski, A. V. Developments in laboratory diagnostics for isocyanate asthma. Curr. Opin. Allergy Clin. Immunol. 2007, 7 (2), 138-145.

85. Wisnewski, A. V.; Stowe, M. H.; Cartier, A.; Liu, Q.; Liu, J.; Chen, L.; Redlich, C. A. Isocyanate vapor-induced antigenicity of human albumin. J. Allergy Clin. Immunol. 2004, 113 (6), 1178-1184.

86. Wisnewski, A. V.; Srivastava, R.; Herick, C.; Xu, L.; Lemus, R.; Cain, H.; Magoski, N. M.; Karol, M. H.; Bottomly, K.; Redlich, C. A. Identification of human lung and skin proteins conjugated with hexamethylene diisocyanate in vitro and in vivo. Am. J. Respir. Crit Care Med. 2000, 162 (6), 2330-2336. 
87. Lange, R. W.; Lantz, R. C.; Stolz, D. B.; Watkins, S. C.; Sundareshan, P.; Lemus, R.; Karol, M. H. Toluene diisocyanate colocalizes with tubulin on cilia of differentiated human airway epithelial cells. Toxicol. Sci. 1999, $50(1), 64-71$.

88. Lantz, R. C.; Lemus, R.; Lange, R. W.; Karol, M. H. Rapid reduction of intracellular glutathione in human bronchial epithelial cells exposed to occupational levels of toluene diisocyanate. Toxicol. Sci. 2001, 60 (2), 348-355.

89. Sabbioni, G.; Hartley, R.; Schneider, S. Synthesis of adducts with amino acids as potential dosimeters for the biomonitoring of humans exposed to toluenediisocyanate. Chem. Res. Toxicol. 2001, 14 (12), 1573-1583.

90. Hettick, J. M.; Siegel, P. D. Determination of the toluene diisocyanate binding sites on human serum albumin by tandem mass spectrometry. Anal. Biochem. 2011, 414 (2), 232-238.

91. Hettick, J. M.; Siegel, P. D. Comparative analysis of aromatic diisocyanate conjugation to human albumin utilizing multiplexed tandem mass spectrometry. International Journal of Mass Spectrometry 2012, 309, $168-175$.

92. Sabbioni, G.; Wesp, H.; Lewalter, J.; Rumler, R. Determination of isocyanate biomarkers in construction site workers. Biomarkers 2007, 12 (5), 468483.

93. Wong, J. L.; Liu, D. Z.; Zheng, Y. T. Lysine conjugate of acrylonitrile as antigenic sites in hemoglobin adducts. J. Pept. Res. 2004, 63 (2), 171174.

94. Pien, L. C.; Zeiss, C. R.; Leach, C. L.; Hatoum, N. S.; Levitz, D.; Garvin, P. J.; Patterson, R. Antibody response to trimellityl hemoglobin in trimellitic anhydride-induced lung injury. J. Allergy Clin. Immunol. 1988, 82 (6), 1098-1103.

95. Hettick, J. M.; Ruwona, T. B.; Siegel, P. D. Structural elucidation of isocyanate-peptide adducts using tandem mass spectrometry. J. Am. Soc. Mass Spectrom. 2009, 20 (8), 1567-1575.

96. Lemons, A. R.; Siegel, P. D.; Mhike, M.; Law, B. F.; Hettick, J. M.; Bledsoe, T. A.; Nayak, A. P.; Beezhold, D. H.; Green, B. J. A murine monoclonal antibody with broad specificity for occupationally relevant diisocyanates. J. Occup. Environ. Hyg. 2014, 11 (2), 101-110. 
97. Wisnewski, A. V.; Liu, J.; Redlich, C. A. Antigenic changes in human albumin caused by reactivity with the occupational allergen diphenylmethane diisocyanate. Anal. Biochem. 2010, 400 (2), 251-258.

98. Malo, J. L.; Ouimet, G.; Cartier, A.; Levitz, D.; Zeiss, C. R. Combined alveolitis and asthma due to hexamethylene diisocyanate (HDI), with demonstration of crossed respiratory and immunologic reactivities to diphenylmethane diisocyanate (MDI). Journal of allergy and clinical immunology 1983, 72 (4), 413-419.

99. Wisnewski, A. V.; Stowe, M. H.; Nerlinger, A.; Opare-Addo, P.; Decamp, D.; Kleinsmith, C. R.; Redlich, C. A. Biomonitoring Hexamethylene diisocyanate (HDI) exposure based on serum levels of HDI-specific IgG. Ann. Occup. Hyg. 2012, 56 (8), 901-910.

100. Sharifi, L.; Karimi, A.; Shokouhi, S. R.; Miri, S.; Heydar, N. H.; Bokaie, S.; Fazlollahi, M. R.; Sadeghniiat, H. K.; Pourpak, Z.; Moin, M. Asthma Symptoms and Specific IgE Levels among Toluene Diisocyanate (TDI) Exposed Workers in Tehran, Iran. Iran J. Public Health 2013, 42 (4), 397-401.

101. Wisnewski, A. V.; Mhike, M.; Hettick, J. M.; Liu, J.; Siegel, P. D. Hexamethylene diisocyanate (HDI) vapor reactivity with glutathione and subsequent transfer to human albumin. Toxicol. In Vitro 2013, 27 (2), 662-671.

102. Pien, L. C.; Zeiss, C. R.; Leach, C. L.; Hatoum, N. S.; Levitz, D.; Garvin, P. J.; Patterson, R. Antibody response to trimellityl hemoglobin in trimellitic anhydride-induced lung injury. J. Allergy Clin. Immunol. 1988, 82 (6), 1098-1103.

103. Ruwona, T. B.; Johnson, V. J.; Hettick, J. M.; Schmechel, D.; Beezhold, D.; Wang, W.; Simoyi, R. H.; Siegel, P. D. Production, characterization and utility of a panel of monoclonal antibodies for the detection of toluene diisocyanate haptenated proteins. J. Immunol. Methods 2011, 373 (1-2), 127-135.

104. Ruwona, T. B.; Johnson, V. J.; Schmechel, D.; Simoyi, R. H.; Beezhold, D.; Siegel, P. D. Monoclonal antibodies against toluene diisocyanate haptenated proteins from vapor-exposed mice. Hybridoma (Larchmt. ) 2010, 29 (3), 221-229.

105. Saetta, M.; Di, S. A.; Maestrelli, P.; De, M. N.; Milani, G. F.; Pivirotto, F.; Mapp, C. E.; Fabbri, L. M. Airway mucosal inflammation in 
occupational asthma induced by toluene diisocyanate. Am. Rev. Respir. Dis. 1992, 145 (1), 160-168.

106. Raulf-Heimsoth, M.; Baur, X. Pathomechanisms and pathophysiology of isocyanate-induced diseases--summary of present knowledge. Am. J. Ind. Med. 1998, 34 (2), 137-143.

107. Kennedy, A. L.; Wilson, T. R.; Stock, M. F.; Alarie, Y.; Brown, W. E. Distribution and reactivity of inhaled 14C-labeled toluene diisocyanate (TDI) in rats. Arch. Toxicol. 1994, 68 (7), 434-443.

108. Kennedy, A. L.; Brown, W. E. Isocyanates and lung disease: experimental approaches to molecular mechanisms. Occup. Med. 1992, 7 (2), 301329.

109. Bentley, A. M.; Maestrelli, P.; Saetta, M.; Fabbri, L. M.; Robinson, D. S.; Bradley, B. L.; Jeffery, P. K.; Durham, S. R.; Kay, A. B. Activated Tlymphocytes and eosinophils in the bronchial mucosa in isocyanateinduced asthma. J. Allergy Clin. Immunol. 1992, 89 (4), 821-829.

110. Maestrelli, P.; Occari, P.; Turato, G.; Papiris, S. A.; Di, S. A.; Mapp, C. E.; Milani, G. F.; Fabbri, L. M.; Saetta, M. Expression of interleukin (IL)-4 and IL-5 proteins in asthma induced by toluene diisocyanate (TDI). Clin. Exp. Allergy 1997, 27 (11), 1292-1298.

111. Herrick, C. A.; Xu, L.; Wisnewski, A. V.; Das, J.; Redlich, C. A.; Bottomly, K. A novel mouse model of diisocyanate-induced asthma showing allergic-type inflammation in the lung after inhaled antigen challenge. J. Allergy Clin. Immunol. 2002, 109 (5), 873-878.

112. Del Prete, G. F.; De, C. M.; D'Elios, M. M.; Maestrelli, P.; Ricci, M.; Fabbri, L.; Romagnani, S. Allergen exposure induces the activation of allergenspecific Th2 cells in the airway mucosa of patients with allergic respiratory disorders. Eur. J. Immunol. 1993, 23 (7), 1445-1449.

113. Maestrelli, P.; Del Prete, G. F.; De, C. M.; D'Elios, M. M.; Saetta, M.; Di, S. A.; Mapp, C. E.; Romagnani, S.; Fabbri, L. M. CD8 T-cell clones producing interleukin-5 and interferon-gamma in bronchial mucosa of patients with asthma induced by toluene diisocyanate. Scand. J. Work Environ. Health 1994, 20 (5), 376-381.

114. Lummus, Z. L.; Alam, R.; Bernstein, J. A.; Bernstein, D. I. Diisocyanate antigen-enhanced production of monocyte chemoattractant protein-1, IL-8, and tumor necrosis factor-alpha by peripheral mononuclear cells 
of workers with occupational asthma. J. Allergy Clin. Immunol. 1998, 102 (2), 265-274.

115. Qin, Z. The use of THP-1 cells as a model for mimicking the function and regulation of monocytes and macrophages in the vasculature.

Atherosclerosis 2012, 221 (1), 2-11.

116. Rogers, P. D.; Thornton, J.; Barker, K. S.; McDaniel, D. O.; Sacks, G. S.; Swiatlo, E.; McDaniel, L. S. Pneumolysin-dependent and -independent gene expression identified by cDNA microarray analysis of THP-1 human mononuclear cells stimulated by Streptococcus pneumoniae. Infect. Immun. 2003, 71 (4), 2087-2094.

117. Cousins, R. J.; Blanchard, R. K.; Popp, M. P.; Liu, L.; Cao, J.; Moore, J. B.; Green, C. L. A global view of the selectivity of zinc deprivation and excess on genes expressed in human THP-1 mononuclear cells. Proc. Natl. Acad. Sci. U. S. A 2003, 100 (12), 6952-6957. 